\title{
Marine harmful algal blooms, human health and wellbeing: challenges and opportunities in the 21 st century
}

ELISA BERDALET ${ }^{1}$, LORA E. FLEMING ${ }^{2}$, RICHARD GOWEN ${ }^{3,4}$, KEITH DAVIDSON $^{4}$, PHILIPP HESS $^{5}$, LORRAINE C. BACKER ${ }^{6}$, STEPHANIE K. MOORE ${ }^{7}$, PORTER HOAGLAND ${ }^{8}$ AND HENRIK ENEVOLDSEN ${ }^{9}$

${ }^{1}$ Institut de Ciències del Mar (CSIC), Passeig Marítim de la Barceloneta, 37-49, 08003 Barcelona, Catalonia, Spain, ${ }^{2}$ European Centre for Environment and Human Health, University of Exeter Medical School, Truro, Cornwall TR1 3 HD, UK, ${ }^{3}$ Fisheries and Aquatic Ecosystems Branch, Agri-Food and Biosciences Institute, Newforge Lane, Belfast BT9 5 PX, UK, ${ }^{4}$ Scottish Association for Marine Science (SAMS), Scottish Marine Institute, Oban, PA37 1QA, UK, ${ }^{5}$ Ifremer, Laboratoire Phycotoxines, BP21105, Rue de l'Ile d'Yeu, 44311 Nantes Cedex 03, France, ${ }^{6}$ National Center for Environmental Health, 4770 Buford Highway NE, MS F-6o, Chamblee, GA $30341,{ }^{7}$ University Corporation for Atmospheric Research, Joint Office for Science Support. Visiting Scientist at Northwest Fisheries Science Center, National Marine Fisheries Service, NOAA, 2725 Montlake Blvd E, Seattle, WA 98112, USA, ${ }^{8}$ Marine Policy Center, Woods Hole Oceanographic Institution, Woods Hole, MA 02543, USA, ${ }^{9}$ Intergovernmental Oceanographic Commission of UNESCO, IOC Science and Communication Centre on Harmful Algae, University of Copenhagen, Universitetsparken 4, 2100 Copenhagen $\varnothing$, Denmark

\begin{abstract}
Microalgal blooms are a natural part of the seasonal cycle of photosynthetic organisms in marine ecosystems. They are key components of the structure and dynamics of the oceans and thus sustain the benefits that humans obtain from these aquatic environments. However, some microalgal blooms can cause harm to humans and other organisms. These harmful algal blooms (HABs) have direct impacts on human health and negative influences on human wellbeing, mainly through their consequences to coastal ecosystem services (fisheries, tourism and recreation) and other marine organisms and environments. HABs are natural phenomena, but these events can be favoured by anthropogenic pressures in coastal areas. Global warming and associated changes in the oceans could affect HAB occurrences and toxicity as well, although forecasting the possible trends is still speculative and requires intensive multidisciplinary research. At the beginning of the 21st century, with expanding human populations, particularly in coastal and developing countries, mitigating HABs impacts on human health and wellbeing is becoming a more pressing public health need. The available tools to address this global challenge include maintaining intensive, multidisciplinary and collaborative scientific research, and strengthening the coordination with stakeholders, policymakers and the general public. Here we provide an overview of different aspects of the HABs phenomena, an important element of the intrinsic links between oceans and human health and wellbeing.
\end{abstract}

Keywords: Harmful algal blooms, human health and wellbeing, marine biotoxins, ecosystem services

Submitted 30 September 2015; accepted 1 October 2015; first published online 20 November 2015

\section{DVERVIEW DF THE CHALLENGES}

Aquatic ecosystems are supported by photosynthetic organisms (e.g. macrophytes, benthic and planktonic microalgae and cyanobacteria) that fix carbon, produce oxygen, and constitute the base of food webs. Under certain circumstances, however, the abundance of some taxa can reach levels that may cause harm to humans and other organisms. These proliferations often are referred to as 'harmful algal blooms' (HABs), a term that includes a variety of species and consequences that humans perceive as adverse. HABs occur in all aquatic environments (e.g. freshwater, brackish and marine) and at all latitudes. In this paper, we focus specifically on the threat that blooms of harmful microalgae pose to the benefits (food supplies, economic activities, tourism and recreation) that the oceans and seas provide to human health and wellbeing (Figure 1).

Of the many thousands of microalgal species described, about 300 are involved in harmful events (see e.g. http:// www.marinespecies.org/hab/index.php). More than 100 of these species, with no apparent physiological, phylogenetic or structural commonalities, produce potent and persistent natural toxins that can be harmful or even lethal to humans and animals (Sournia, 1995; Moestrup et al., 2009). The chemically diverse compounds synthesized by toxic HABs species have been associated with different syndromes in humans (Box 1), and many may also adversely affect certain fish, seabirds, reptiles and marine mammals (Box 2). 


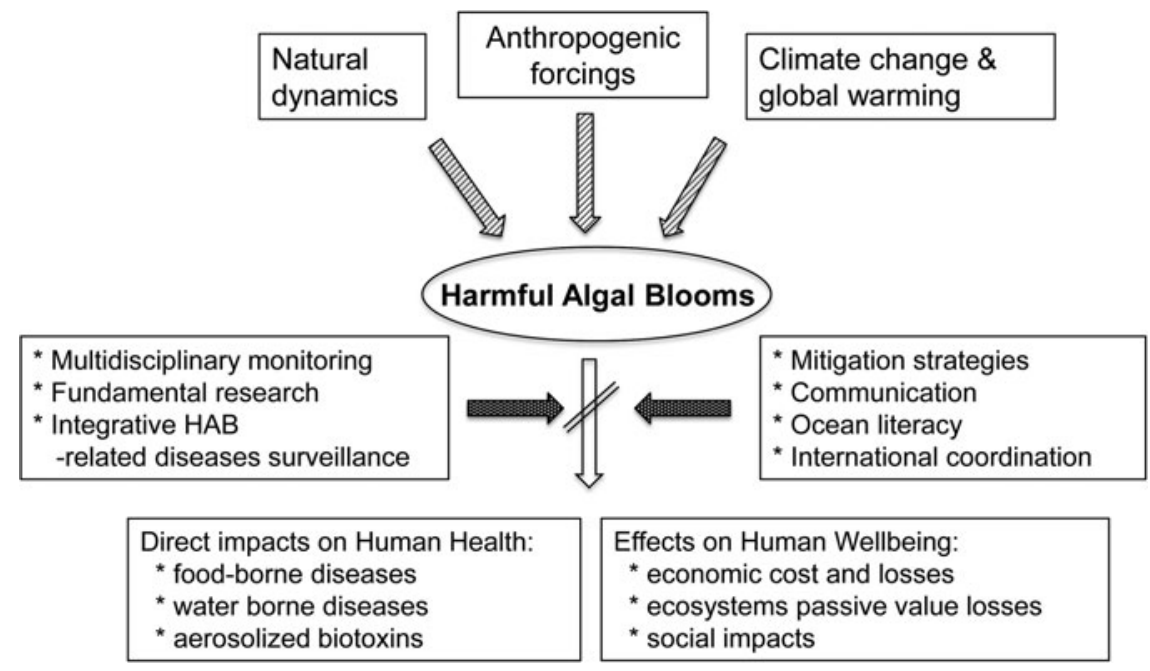

Fig. 1. Conceptual links between the main drivers (natural dynamics, climate change and global warming and other anthropogenic forcings) involved in the occurrence of HABs, the main impacts of HABs on humans health and wellbeing, and some of the tools to decrease these effects.

In humans, toxicity is caused by the ingestion of contaminated seafood products (fish or shellfish), skin contact with toxin-contaminated water, or the inhalation of aerosolized toxins or noxious compounds. In the case of food-borne poisonings (Figure 2), HAB toxins are bio-concentrated, often without apparently harming the vector marine organism that ingested the toxin, and transferred up through the food web to humans. Toxic effects usually occur when the HAB species producing the toxin is present in high abundance, although seafood poisoning also can be caused by highly toxic microalgae at low abundances. In addition to the direct impacts on human health, these toxic outbreaks have associated consequences on other components of human wellbeing both in terms of their socio-economic impact and costs. Namely, HAB occurrences can lead to the closure of important shellfisheries (e.g. Jin et al., 2008) and increases in the costs of monitoring and management (Hoagland et al., 2002).

Another hazardous effect of some HABs taxa is the production of excess algal biomass, which can affect individual organisms and ecosystems in different ways (Box 2). When large blooms decay, the subsequent degradation by bacteria of accumulated biomass reduces oxygen concentrations in marine waters and can cause hypoxia, especially in bottom waters isolated by density gradients from surface waters. In addition to the benthic faunal mortalities related to oxygen depletion, the unpleasant appearance of surface scums and bad odours associated with some HABs can dissuade tourists from visiting coastal recreation areas (Scatasta et al., 2003). Phycotoxins also can cause morbidities and mortalities of wild and farmed fish (gill damage), birds (hypothermia), marine mammals, or certain invertebrates, resulting in economic losses in finfish aquaculture and tourism, and losses of the non-market, 'passive' values that humans may have for protected species or extraordinary ecosystems. These examples illustrate how HABs may also decrease the non-market, passive use values of marine ecosystems and their services, thereby limiting the way in which the marine environment can enhance the quality of life and wellbeing for humans (Hoagland \& Scatasta, 2006).

Blooms of microalgae, including those deemed by humans to be harmful (see for instance, http://haedat.iode.org), are a natural phenomenon (e.g. Smayda, 1997; Margalef, 1998;
Gowen et al., 2012 and references cited therein) and awareness of $\mathrm{HAB}$ events is embedded in the cultural heritage of many coastal human communities. Historically, this awareness has helped to mitigate some of the adverse effects of HABs. However, at present, increasing the information about public health risks and the strategies that scientists and policy makers, working together, can address to decrease the impacts of HABs on human health and wellbeing could still be beneficial. It is important to recognize that there is not a realistic way to prevent $\mathrm{HABs}$ occurrence as it results from complex interactions among physical, chemical, and biological processes operating at different spatio-temporal scales in the marine environment. Over the last 50 years, human modifications of the marine environment, particularly those occurring at the land-sea interface, may have influenced the incidence of HABs in certain locations. These modifications include the alteration of water circulation in harbours and artificial beach construction, the dispersal of species through ship ballast waters, and nutrient enrichment (Hallegraeff \& Bolch, 1992; Anderson et al., 2002; Davidson et al., 2014).

Superimposed on these stresses, climate change is already leading to temperature increases in some areas of the earth's oceans, and warmer waters could affect the occurrence of HABs (Moore et al., 2008; Backer \& Moore, 2011; Hallegraeff, 2010 and references cited therein; Gowen et al., 2012). Specifically, changes in the frequency, intensity, and geographic extent of HABs may occur, but the possible responses are likely to be highly species-specific, given the diverse toxicity, physiology, biology, and ecology of HAB organisms. Thus, the forecasting of such changes is still quite speculative, requiring long time series of ecological processes, as well as more focused research (including modelling).

This review was stimulated by discussions at the 'Oceans and Human Health at the beginning of the 21st century' workshop held in Bedruthan (Cornwall, UK) in March 2014. This paper is not an exhaustive review of all the different factors concerning the occurrence of $\mathrm{HAB}$ events (see e.g. GEOHAB, 2001, 2005, 2006, 2008, 2010, 2012; Zingone \& Wyatt, 2005; Gowen et al., 2012). Instead, we summarize the main direct impacts of HABs on human health. We describe briefly the influences of HABs on human wellbeing, mainly 
through the negative consequences to ecosystem services and other marine organisms and environments. Other aspects of the possible interconnections between human wellbeing and HABs have yet to be investigated. Based on this evidence, we highlight the main challenges posed by marine HABs, and we discuss the tools available to respond to HABs in the coming years, especially within the context of climate warming.

\section{DIRECT IMPACTS DF HABS DN $H \cup M A N H E A L T H$}

As noted above, the direct impacts of HABs in marine waters on human health are linked to poisoning (Box 1) associated with eating contaminated seafood (Figure 2), skin contact with contaminated water, and/or inhaling aerosolized biotoxins. In addition to human health conditions associated with known toxins produced by microalgae, there exist emerging phycotoxins and risks of poisoning through biotoxin contaminated desalinated drinking water. In the remaining text, the terms 'biotoxin', 'phycotoxin' or 'toxin' will be used to refer to toxic compounds synthesized by the marine microalgae.

Box 1. Main HAB toxic syndromes (in alphabetical order), Biotoxins ( $\underline{\mathrm{T}})$, Causative Organisms (O)$)$, Symptoms (S), Route of exposure (E), Main Geographic Affected Areas (A), some References ( $\underline{\text { R }) \text {. }}$

*Amnesic Shellfish Poisoning (ASP):

T: Domoic acid and isomers

O: Pseudo-nitzschia spp. and Nitzschia

S: Nausea, vomiting, diarrhoea, headache, dizziness, confusion, disorientation, short-term memory deficits, and motor weakness. Severe cases result in seizures, cardiac arrhythmia, respiratory distress, coma, and possibly death

E: Consumption of shellfish (possibly, fish)

A: Worldwide, affecting seafood and fisheries activities

R: Bates et al. (1989); Martin et al. (1993); Scholin et al. (2000); Fehling et al. (2004)

\section{*Azaspiracid Shellfish Poisoning (AZP):}

T: Azaspiracid and its derivatives

O: Amphidomataceae (Amphidoma languida, Azadinium spinosum, Azadinium poporum, Azadinium dexteroporum)

S: Nausea, vomiting, severe diarrhoea, abdominal cramps; effects on mice tests include severe damage to the intestine, spleen and liver tissues in animal tests

E: Consumption of shellfish

$\bar{A}$ : Seafood poisoning reported from shellfish in Europe and North America

R: Twiner et al. (2008, 2012a, b, 2014); Klontz et al. (2009); Tillmann et al. (2009, 2014); Hess et al. (2014)

\section{*Ciguatera Fish Poisoning (CFP):}

\section{T: Ciguatoxin}

O: Gambierdiscus spp., Fukuyo spp.

$S$ : Nausea, vomiting, diarrhoea, numbness of mouth and extremities. Neurological symptoms may persist for several months

E: Consumption of coral reef fish

A : Endemic in the tropics and subtropics, expanding to temperate latitudes

R: Friedman et al. (2008); Litaker et al. (2010); Chinain et al. (2010a, b); Tester et al. (2014)

*Diarrhetic Shellfish Poisoning (DSP):

T: Okadaic acid and its derivatives (dinophysistoxins)

O: Dinophysis spp., Prorocentrum lima

S: Nausea, vomiting, severe diarrhoea, abdominal cramps, respiratory distress

E: Consumption of shellfish

A: Worldwide, affecting seafood and fisheries activities

R: Yasumoto et al. (1980); Kat (1983); Reguera \& Pizarro (2008); Raine et al. (2010); Reguera et al. (2014)

*Neurotoxic Shellfish Poisoning (NSP) and respiratory irritation:

\section{T: Brevetoxins}

O: Karenia brevis (predominantly)

$\underline{S}$ : By seafood poisoning: nausea, temperature sensation reversals, muscle weakness, and vertigo. Exposure to aerosols related to respiratory and eye irritation particularly for asthmatics

E: Consumption of shellfish (and fish at least for marine mammals); inhalation of marine aerosols during active blooms

A: Particularly in the Gulf of Mexico and Japan, China, Korea, New Zealand

R: Watkins et al. (2008); Fleming et al. (2011)

*Palytoxicosis (foodborne poisoning) and other irritative symptoms:

\section{T: Palytoxin, Ostreocin, Ovatotoxin}

O: Ostreopsis spp.

S: Associated to food-borne poisoning: nausea, vomiting, severe diarrhoea, abdominal cramps, lethargy, tingling of the lips, mouth, face and neck, lowered heart rate, skeletal muscle breakdown, muscle spasms and pain, lack of sensation, myalgia and weakness, hypersalivation, difficulty in breathing. Exposure to aerosols: eye and nose irritation, whinorrhoea, general malaise, fever. Cutaneous irritations in beach swimmers

E: Consumption of seafood; inhalation of marine aerosols; direct contact with water A: Food-borne poisoning in the tropics and subtropics; respiratory and cutaneous irritations in Mediterranean beaches

R: Deeds \& Schwartz (2010) (references therein); Tubaro et al. (2011); Ciminiello et al. (2010, 2013); Vila et al. (2012)

*Paralytic Shellfish Poisoning (PSP):

T: Saxitoxin and derivatives

O: Alexandrium spp., Pyrodinium bahamense var. compressum and other species, Gymnodinium catenatum, some calcareous red macroalgae

$\underline{S}$ : Nausea, vomiting, diarrhoea, numbness and tingling of 
the lips, mouth, face and neck. Severe cases can result in paralysis of the muscles of the chest and abdomen leading to death

E: Consumption of shellfish, crustaceans, fish

A: Worldwide, affecting shellfish activities

R: Ayres (1975); Gaines \& Taylor (1985); Anderson et al. $(1989,2005 a, b)$

\section{Food-borne diseases: overview}

Poisoning through the ingestion of biotoxin-contaminated seafood is the best documented impact that HABs have on humans (Figure 2, Box 1). The poisoning process involves the bio-concentration of the biotoxins by filter feeding fauna (mostly bivalve molluscs, e.g. Mytilus spp.) which themselves are generally unaffected by these compounds. Other vectors include certain marine gastropods (e.g. whelks and moon snails), some crustaceans (e.g. crabs), echinoderms and fish (e.g. some planktivorous fishes or belonging to the tetraodontidae family) that acquire biotoxins through the food web (Deeds et al., 2008). Toxins accumulated in seafood tissues can remain for considerable lengths of time after the bloom has declined in the seawater. Further, these biotoxins are not destroyed by cooking or by the processing of seafood products, and because they do not have distinctive odours or taste, they can be detected only through specialized laboratory testing (Zaias et al., 2010).

Most algal toxins are primarily neurotoxins (e.g. brevetoxins affecting the $\mathrm{Na}^{+}$channels), although they are also known to affect human health through other routes (e.g. okadaic acid affecting phosphatase activity). The various toxic compounds can produce a wide range of symptoms and thus have been associated with several clinically described syndromes depending on the main symptomatic mode (Box 1): amnesic (ASP), azaspirazid (AZP), diarrhetic (DSP), neurotoxic (NSP) and paralytic (PSP) shellfish poisonings and ciguatera fish poisoning (CFP). The syndromes can present with symptoms from the nervous, digestive, respiratory, hepatic, dermatological or cardiac systems (e.g. Baden \& Trainer, 1993). The effects can be acute (e.g. paralytic shellfish poisoning can occur within minutes to hours; Medcof, 1985) and can last for weeks to months (e.g. ciguatera fish poisoning; Friedman et al., 2008). Although there is considerable knowledge on the acute health effects caused by HAB biotoxins, many of the toxicological mechanisms are incompletely understood. In addition, we know little about the chronic effects of these biotoxins, either from acute exposure that produces longlasting damage, or from chronic low-level exposures over long periods of time.

For the food-borne syndromes, the prevention of contaminated shellfish reaching the markets (by monitoring the causative species and/or the presence of biotoxin in seafood in real time) is currently the only effective way to protect human health. In fact, well-structured monitoring programmes targeting the causative organisms and toxins in commercial seafood associated with the clinical syndromes (i.e. ASP, AZP, DSP, NSP and PSP) have proven effective in reducing the human exposure to biotoxins in many areas of the world. Information about operative $\mathrm{HAB}$ monitoring programmes is not compiled at a worldwide scale, only at regional as for the North Atlantic by the ICES (International Council for the Exploration of the Sea) - IOC UNESCO Working Group on Harmful Algal Blooms Dynamics (http://www.ices.dk/community/groups/Pages/WGHABD.aspx). However, monitoring could be enhanced by complementing it with additional actions such as informing the public in non-commercial areas affected by HABs (e.g. Reich et al., 2015) and increasing the understanding of the complex processes involved in harmful events (e.g. Whyte et al., 2014).

Unfortunately, due to increased human pressure on coastal marine ecosystems together with global warming, harmful blooms may occur in areas where they have not previously been reported (Trainer et al., 2013). Also, new biotoxins are continually being identified. For these cases, toxin detection and identification of the causative organism represent new challenges for monitoring and management procedures (Turner et al., 2015). It is also noteworthy that for ciguatera fish poisoning, the most frequent cause of $\mathrm{HAB}$-associated poisoning in tropical waters, effective procedures to protect human populations are lacking (see Sections 'Most common biotoxin syndromes in temperate latitudes' and 'Better quantification and prevention of the impacts on human health: HAB-related disease surveillance'). Increased international tourist travel and trade in

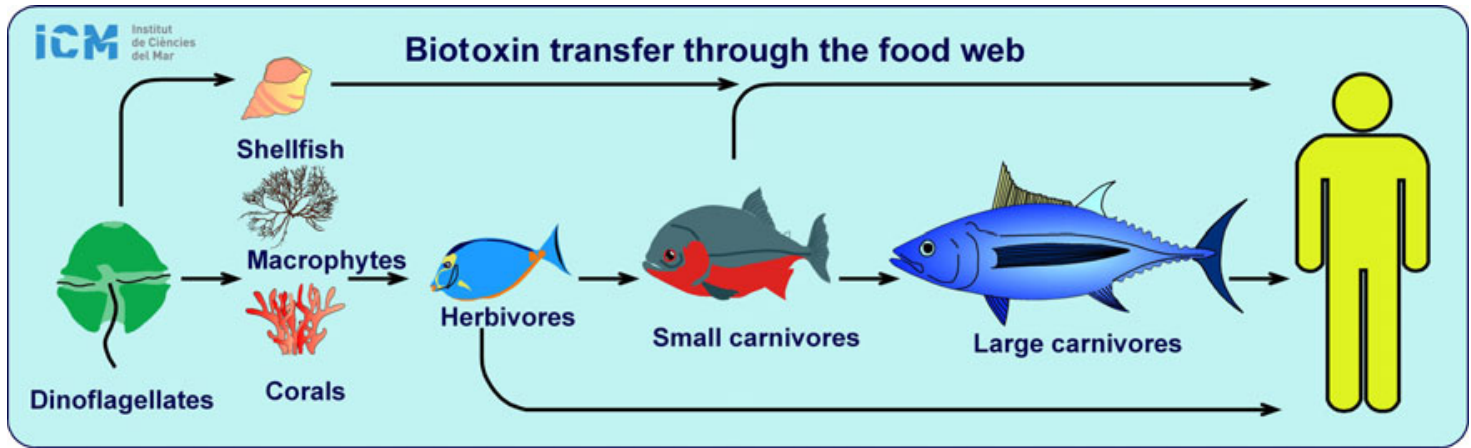

Fig. 2. Biotoxin transfer pathways through the marine food web to humans. A biotoxin-producing organism, such as the dinoflagellates Dinophysis acuta or Alexandrium catenella, is bioaccumulated by shellfish, which are apparently not affected by saxitoxin or lipophilic biotoxins. Consumption of the contaminated shellfish is a traditional way of diarrhetic or paralytic poisoning (DSP, PSP). Alternatively, some toxicogenic species attach to surfaces (macrophytes, corals) by an endogenous mucus (e.g. Gambierdiscus, Ostreopsis, Prorocentrum lima). Fragments of corals or macrophytes covered by the microalgae enter the food web through ingestion by herbivorous fish. This is the transmission mechanism of ciguatera fish poisoning (CFP). Certain fishes can also experience some sort of poisoning. 
seafood can lead to poisonings in areas far from where the fish is caught (Mattei et al., 2014).

\section{MOST COMMON BIOTOXIN SYNDROMES IN}

\section{TEMPERATE LATITUDES}

In the temperate latitudes of Europe, South Africa, Asia, Australia, North America and South America, the most common HABs cause amnesic (ASP), azaspiracid (AZP), diarrhetic (DSP), neurotoxic (NSP) and paralytic (PSP) shellfish poisonings (Box 1).

Domoic acid, a neurotoxin produced by various species of Pseudo-nitzschia and Nitzschia, was identified as responsible for causing an outbreak of amnesic shellfish poisoning in humans (involving 107 illnesses and three deaths) after the consumption of blue mussels from Prince Edward Island (Canada) in 1987 (Bates et al., 1989; Todd, 1993). Since then, blooms of these pennate diatoms have resulted in a range of, often large-scale, shellfish toxicity events, affecting humans and other large vertebrates (see Section 'Impacts of $\mathrm{HABs}$ on non-market, passive use values of marine ecosystems' and Box 2). Symptoms of ASP poisoning in humans include short- and long-term memory loss.

The azaspiracids, first identified in mussels from Ireland in 1995 (Satake et al., 1998), belong to a novel group of polyether biotoxins produced by the small armoured dinoflagellate Azadinium spinosum (Tillmann et al., 2009; see also Section 'Improving monitoring and research needs to forecast and predict HAB events'). This biotoxin causes symptoms similar to those displayed by DSP (Twiner et al., 2008), although slowly progressing paralyses have also been observed in mouse assays. Azaspiracids have now been found in a number of other European Union countries with $\sim 20$ different analogues of AZA identified.

Diarrhetic shellfish poisoning (DSP) was first linked to the presence of Dinophysis fortii in Japan (Yasumoto et al., 1980) and to D. acuminata in Dutch coastal waters (Kat, 1983), and it was recorded after consumption of mussels containing DSP biotoxins from the Northern Adriatic coast in 1989 (Boni et al., 1992). Diarrhetic shellfish poisoning is caused by okadaic acid or its derivative dinophysistoxins, produced by 10 species of the genus Dinophysis, two species of the genus Phalachroma (Reguera et al., 2012), and Prorocentrum lima (Koike et al., 1998). In humans, DSP biotoxins bind to phosphatase receptors, causing severe, but not usually fatal, gastrointestinal symptoms (with a rapid onset). DSP outbreaks are common in Europe, affecting shellfish consumers in at least 10 countries. On occasion, outbreaks have resulted in large numbers of people becoming ill, and shellfish harvest areas have been closed for up to 10 months (e.g. Fraga \& Sánchez, 1985; Haamer et al., 1990; Lassus et al., 1985; Ramstad et al., 2001; Blanco et al., 2005, 2013; Vale et al., 2008; review by Reguera et al., 2014).

For regulatory purposes, the more recently discovered pectenotoxins and yessotoxins are classified within the DSP group. Pectenotoxins are produced by some of the Dinophysis species including D. acuta and D. acuminata. Yessotoxins induce similar symptoms but are produced by the dinoflagellates Lingulodinium polyedrum and Protoceratium reticulatum (Paz et al., 2004 and references cited there in). Recently, experts have recommended the deregulation of pectenotoxins and yessotoxins due to research results finding a non-toxic effect of the oral administration of these substances in mice (ICES, 2006).

Brevetoxin is the collective name given to a class of biotoxins that causes neurotoxic shellfish poisoning (NSP). Brevetoxins are produced primarily by the naked dinoflagellate Karenia brevis. In the Gulf of Mexico, and in isolated instances along the South-east Atlantic coast of the USA, blooms of $K$. brevis have caused water discolouration, large-scale finfish mortality events, human poisonings due to the consumption of shellfish, and respiratory problems in asthmatics caused by inhalation of biotoxin in the form of an aerosol (Morris et al., 1991; Magaña et al., 2003; Kirkpatrick et al., 2004; Watkins et al., 2008; Fleming et al., 2011). Notably, NSP has not been linked to fatalities in humans (van Dolah, 2000). The occurrence of toxic $K$. brevis red tides was recorded as early as 1648 in the Western Gulf of Mexico and since the 1840s in Florida (Magaña et al., 2003; Kirkpatrick et al., 2004).

Paralytic shellfish poisoning (PSP) is caused by saxitoxin and its derivatives, potent neurotoxins that can cause headache, nausea, facial numbness, and, in severe cases, respiratory failure and death. The first likely cases in the UK were in 1827 in Leith and in 1888 in Liverpool (Ayres, 1975). In British Columbia (Gaines \& Taylor, 1985) and Norway (Yndestad \& Underdal, 1985), the first recorded outbreaks of PSP were in 1793 and 1901 respectively. Medcof (1985) reported toxic shellfish episodes from the 1930s and 1940s. In Europe and North America, PSP is mainly associated with blooms of the thecate (armoured) dinoflagellate genus Alexandrium, mainly A. tamarense/funyense/catenella group and A. minutum (Medlin et al., 1998; Higman et al., 2001; Lilly et al., 2007; Touzet et al., 2007), although some Alexandrium species and strains are non-toxic. In Asia (the Philippines, Malaysia, Brunei and Indonesia, Papua New Guinea), PSP is mainly produced by outbreaks of the armoured dinoflagellate Pyrodinium bahamense var. compressum. In the Philippines, this species was responsible for 1995 cases with 117 deaths linked to PSP toxicity between 1983 and 1999 (Azanza, 1999; Azanza \& Taylor, 2001).

\section{CIGUATERA FISH POISONING (CFP)}

Worldwide, ciguatera fish poisoning (CFP) is the most common food poisoning associated with a natural, nonbacterial chemical, and it occurs throughout the tropics, particularly in vulnerable island communities such as the Pacific Island Countries and Territories (PICTs). Ciguatoxins, or their precursors, are produced by several species of the benthic dinoflagellate genus Gambierdiscus (mainly G. toxicus). The biotoxins are modified through metabolic pathways in the food web of coral reefs, and they tend to accumulate in fish, particularly larger carnivorous species such as barracuda (Sphyraena spp., Heymann, 2004), but they also have been found in more than 400 fish species. After consuming ciguatoxin-contaminated fish, a range of acute neurological, gastrointestinal and cardiac symptoms have been reported, with some individuals experiencing chronic neurological symptoms lasting weeks to months (e.g. Freudenthal, 1990; Friedman et al., 2008; Skinner et al., 2011, and references cited therein). Repeated exposure to ciguatoxins can reportedly exacerbate the acute ciguatera symptoms (Bagnis et al., 1979; Pottier et al., 2001).

CFP is a threat to public health throughout tropical areas, and it is the most widespread, and hence best described, in the island 
nations of the Pacific and the Caribbean (for reviews, see Brusle 1997; Lehane \& Lewis, 2000; Friedman et al., 2008; and references therein). Unfortunately, the real extent of illness is not well documented due to under-reporting and misdiagnosis (McKee et al., 2001; Radke et al., 2015). Thus, its impacts on human communities and ecosystem health are still poorly understood. Data from the Health and Fisheries Authorities of 17 PICTs (Skinner et al., 2011) estimated a mean annual incidence of 104 cases per 100,000 people across the region during 1973-83. Based on these estimates, the recorded CFP incidence in the South Pacific should be increased by 60\%, i.e. up to 194 cases per 100,000 people between 1998-2008.

CFP illness rates exhibit high variability, reaching particularly elevated levels in some areas. For instance, up to 497 cases per 10,000 population per year were recorded in French Polynesia including Raivavae Island (Austral archipelago) between 2000-08 (Chateau-Degat et al., 2009; Chinain et al., 2010b), and up to 440 cases per 10,000 population per year in the Caribbean between 1996-2006 (Tester et al., 2010). Despite uncertainty about the real incidence, data suggest that CFP constitutes an acute and chronic illness with major public health significance at both local and more widespread levels. In future, the health problem could be exacerbated due to anthropogenic pressures, such as the increased development of coastal zones, ocean warming (e.g. Villareal et al., 2007; Kibler et al., 2015), or natural disasters, such as hurricanes. These pressures can lead to the damage of coral reefs, favouring more resilient macroalgae that constitute new surfaces for the proliferation of the involved toxicogenic benthic dinoflagellates (e.g. Chateau-Degat et al., 2005; Tester et al., 2010).

It is inherently difficult to cope with CFP as a public health problem. For example, the risks of CFP often have been traditionally 'managed' by native fishermen using their local, traditional knowledge, who may warn each other about areas where ciguatoxin-contaminated fish are known to occur. With increasing trade and coastal tourism, CFP cases could occur in non-tropical areas, where ciguatera often goes unrecognized or diagnosed only after expensive investigation (Epelboin et al., 2014; Mattei et al., 2014). There is neither a reliable, cost-effective method for detecting the biotoxin nor is there a biomarker to diagnose the illness in humans. A review by Friedman et al. (2008) describes the clinical course of CFP and its possible treatments, many of which may be unclear to other healthcare providers and public health practitioners, even in endemic areas.

\section{POISONING BY PALYTOXIN AND ANALOGUES}

Ostreopsis is a dinoflagellate genus co-occurring with Gambierdiscus. In tropical Indo-Pacific latitudes, Ostreopsis has been associated with poisoning after the ingestion of clupeid fishes, crabs or sea urchins contaminated with palytoxin (PLTX) (Noguchi et al., 1987; Taniyama et al. 2003; see review by Deeds \& Schwartz, 2010, and references cited therein). This compound and its analogues (Ciminiello et al., 2011, 2015 and references therein; Brissard et al., 2015) are among the most potent biotoxins of marine origin. Nevertheless, in spite of the well-documented but very limited number of severe PLTX-related poisoning cases in these tropical areas, the true risk of PLTX poisoning through seafood consumption in humans is difficult to assess. This is due to the co-occurrence of PLTX with other seafood biotoxins (e.g. ciguatoxins, saxitoxins and tetrodotoxin), the distribution of PLTX mainly in the tropical areas of developing nations with little surveillance and reporting, and its prevalence in reef species that are not commercially harvested.

Ostreopsis seems to be expanding to temperate latitudes (Rhodes, 2011), and recurrent blooms have occurred in Mediterranean waters during the last two decades (e.g. Mangialajo et al., 2011; Illoul et al., 2012). In this region, Ostreopsis proliferations have been related to aerosol exposures at bathing beaches (see Section 'Ostreopsis cf. ovata and respiratory irritations') and macrofaunal mortalities (Box 2). Fortunately, to date, food poisonings related to the PLTX-like group have not been reported in the Mediterranean, although the biotoxin has been detected in certain marine fauna (e.g. Aligizaki et al., 2011; Biré et al., 2013; Brissard et al., 2014; Ciminiello et al., 2015). The European regulation to monitor PLTX has not yet become established, although the Panel on Contaminants in the Food Chain (CONTAM Panel) of the European Food Safety Authority (EFSA, 2009) assessed the risks to human health associated with the presence of PLTX-group biotoxins in shellfish, recommending a maximum concentration of $30 \mu \mathrm{g}$ eqPLTX $\mathrm{kg}^{-1}$ fresh weight. Overall, the few available data suggest a growing potential risk of seafood contamination (from commercial or recreational fishing or aquaculture) in Mediterranean coastal waters (especially in those affected by recurrent Ostreopsis blooms).

The possible transfer and accumulation of the PLTX-like group of biotoxins through the food web to humans should be investigated further. Because Ostreopsis exhibits both benthic and planktonic phases (Bravo et al., 2012), its dispersion is facilitated, increasing the number of seafood types that could become contaminated and complicating its monitoring. The planktonic stage can contaminate filter-feeding bivalves (e.g. mussels), while the benthic stage can enter the food chain through herbivores (e.g. sea urchins, crabs, gastropods, salps) that feed on macroalgae (Brissard et al., 2014). PLTX-like biotoxins can then be transferred to omnivores and carnivores, including humans.

\section{EMERGING BIOTOXINS}

Cyclic imines

Cyclic imines (gymnodimine, spirolides, pinnatoxins and others) have been produced reportedly by a number of dinoflagellates (Karenia selliformis, Vulcanodinium rugosum, Alexandrium ostenfeldii and A. peruvianum). They are classified typically as fast-acting biotoxins due to the rapid mortality occurring in the mouse bioassay for lipophilic biotoxins (Molgó et al., 2014, and references cited therein). Both gymnodimine and pinnatoxins had been associated initially with acute human food poisoning events (Seki et al., 1995; Uemura et al., 1995). Further studies indicated that other biotoxins (i.e. brevetoxins in the case of the New Zealand shellfish poisoning assumed to be caused by gymnodimine) or bacterial (Vibrio) contamination (in the case of the Chinese poisoning assumed to be caused by pinnatoxins) were in fact responsible. Pinnatoxin-G has been reported worldwide (e.g. Rhodes et al., 2010, 2011; Rundberget et al., 2011; McCarron et al., 2012), with the highest levels found in a Mediterranean lagoon in the south of France (Hess et al., 2013). It should be pointed out, however, that no food-poisoning-related events have yet been documented. The chemical stability of this biotoxin to both acids and bases (Jackson et al., 2012) and the high binding affinity to the nicotinic acetylcholine (nACh) receptor raises the spectre of potentially harmful effects to human health due to the chronic exposure of even low levels of pinnatoxins (Molgó et al., 2014). 


\section{$B M A A$}

$\beta$-N-methylamino-L-alanine (BMAA), a non-protein amino acid initially reported to be produced by certain cyanobacteria proliferating in freshwater habitats (Cox et al., 2005), has been recently confirmed in marine diatoms (Jiang et al., 2014a) and in seafood from marine and coastal waters (Brand et al., 2010; Réveillon et al., 2014, 2015). Exposure to BMAA has been linked to an increased risk of neurodegenerative diseases such as amyotrophic lateral sclerosis (ALS), Parkinson's and Alzheimer's diseases (Bradley et al., 2013). Marine cyanotoxins in general are a potential cause of unexplained acute food poisoning (Golubic et al., 2010; Roué et al., 2013, 2014). Additional research is needed to confirm both these findings and the possible epidemiological associations between BMAA and neurodegenerative diseases.

\section{Macro-algae}

Food poisoning from macroalgae has been reported from Asian countries where such foodstuffs are traditionally consumed. Particularly important are the polycavernosides found in Gracilaria edulis (Louzao et al., 2014, and references cited therein). As postulated by Daigo (1959), domoic acid has now been confirmed as a metabolite in Chondria armata following the laboratory culture of these macroalgae (Jiang et al., 2014b). The occurrence of domoic acid and other glutamate receptor agonists in macroalgae may be of importance in studies on the effects of chronic exposures to subacute biotoxin concentration.

EFFECTS OF CHRONIC AND SUBACUTE EXPOSURE Marine biotoxins have traditionally been known for their acute effects. Consequently, regulation at a global scale (FAO, Codex alimentarius) has focused on preventing acute poisoning events (Lawrence et al., 2011). Only a few studies have investigated either chronic effects from an acute exposure episode or chronic exposure to sub-acute levels over time in humans. Some studies, using in vivo models, have shown that there may be some adverse health effects from low-level exposures (either single or repeated) to, for example, domoic acid. Levin et al. (2005) demonstrated that prenatal rats exposed to domoic acid exhibited postnatal effects, e.g. scopolamine susceptibility. In this study, rats showed persistent hypo-activity, and female offspring in particular showed poor performance in a maze, following a single low-dose early postnatal exposure to domoic acid. Baron et al. (2011) reported locomotor disorders in rats exposed to a low level of domoic acid. Finally, low-level repeated exposure over a 36-week period in zebra fish also led to gene alteration and impairment of mitochondrial function at cellular level (Lefebvre et al., 2012; Hiolski et al., 2014).

Sub-acute effects are also a potential problem for repeated or chronic ingestion of low doses of saxitoxins via drinking water produced from desalination of seawater. Until now, saxitoxins have been regulated only on the basis of their acute effects: a maximum permissible level of $3 \mu \mathrm{g} \mathrm{L}{ }^{-1}$ has been established for drinking water in Australia, Brazil and New Zealand. Recent studies suggest, however, that the effects of chronic ingestion of saxitoxins may include the alteration of antioxidant defences and the induction of oxidative stress in the brains and livers of mammals (Ramos et al., 2014; Silva et al., 2014). As mentioned above, the cyclic imine biotoxins also have the potential to interact with receptors involved in neurodegenerative diseases such as Parkinson's and Alzheimer's diseases (Molgó et al., 2014). Interestingly, in both in vitro and in vivo studies, gymnodimine and 13-desmethyl spirolide $\mathrm{C}$ showed some protective effects against Alzheimer's disease, and hence these compounds should be considered for further research into their possible therapeutic applications (Alonso et al., 2011a, b, 2013).

\section{CO-EXPOSURE AND EXPOSURE TO MIXTURES}

Co-exposure to different agents can lead to confounding diagnoses in patients. For example, bacterial contamination in shellfish may lead to gastrointestinal illness (diarrhoea and vomiting) similar in degree to that caused by okadaic acid. Normally, the onset of illness following the consumption of shellfish contaminated with biotoxins is earlier (a few hours) than for those contaminated with bacterial pathogens (12$24 \mathrm{~h}$ ), because bacteria typically require a period of incubation in the patient before causing the full effect.

Exposure to mixtures of different groups of biotoxins is another issue that has not been well studied. Many studies have reported the co-occurrence of biotoxins in single algal species or shellfish that were contaminated by different algal species simultaneously, so the issue should be considered seriously (Hess, 2002, 2010; Amzil et al., 2008; Twiner et al., 2008; Reguera et al., 2012; Suikkanen et al., 2013). In particular, there is a concern that some of the compounds that do not normally cause acute shellfish poisoning in humans (e.g. yessotoxins), may be absorbed following damage to the intestinal tract caused by other biotoxins known to cause harm to humans, (e.g. okadaic acid and azaspiracids). As pure biotoxin supplies are very limited for most of the HAB biotoxins, only a few studies have investigated this potential hazard. Aasen et al. (2011) investigated the combination of azaspiracids with yessotoxins and did not observe any potentiation when orally co-administered at sub-acute levels to mice. Similarly, even a combination of azaspiracids with okadaic acid, two biotoxins known for their potential to cause harm to the human digestive tract, did not cause synergistic effects when orally administered to mice at sub-acute levels (Aune et al., 2012). The combination of okadaic acid and yessotoxins did not cause any increased toxicity in the oral mouse model (Sosa et al., 2013). It should be noted that the digestive tract of mice differs significantly from that of humans (notably in $\mathrm{pH}$ ), however, and further studies (possibly involving primates) may be necessary to rule out the likelihood of synergistic damage. Finally, some potentiation of domoic acid by peptaibols, a fungal metabolite, was shown in a fly larval model (Ruiz et al., 2010). These varied findings are very much dependent on the biological model used, and they should be considered as very preliminary in their nature. Longitudinal studies of humans exposed naturally to mixtures of biotoxins at individually low levels over long periods of time are needed.

\section{Water-borne diseases}

In fresh waters, cyanobacteria blooms constitute the main hazard to the health of humans (and other animals), mainly through the contamination of drinking waters by cyanotoxins, such as microcystins (see e.g. Nishiwaki-Matsushima et al., 1992; Falconer, 1998; Stewart et al., 2008). Direct cutaneous contact, exposure to aerosols, or swallowing water during occupational or recreational activities conducted in freshwater 
environments affected by cyanobacteria blooms, also can cause health problems. In contrast, there is no published evidence, at present, of risks for adverse health effects in humans from swallowing seawater containing toxic marine microalgae, but this possibility cannot be discarded.

Toxic HABs have recently emerged as a potential risk for the contamination of drinking water supplied by desalination systems. Worldwide, desalination is rapidly growing to provide water for domestic consumption and industrial uses. In 2012, there were more than 14,000 desalination plants in 150 countries (Anderson \& McCarthy, 2012). About $50 \%$ of this capacity was located in the West Asia Gulf region, $17 \%$ in North America, $10 \%$ in Asia (apart from the Gulf), $8 \%$ in North Africa and $7 \%$ in Europe. In 2008, the installed capacity was 52.3 million $\mathrm{m}^{3}$ per day. Based on a growth rate of $12 \%$ per year, the global production of freshwater by desalination will have reached a capacity of 94 million $\mathrm{m}^{3}$ per day by 2015 .

Chemical and physical properties, such as the molecular weight of the common HAB biotoxins (saxitoxins, brevetoxins and domoic acid, i.e. 300-900 Da), suggest that they should be efficiently removed by reverse osmosis in the desalinization process. Support for this assumption was provided by Seubert et al. (2012) in their study combining laboratory tests and a 5-year monitoring of an operational plant in California. It has been noticed, however, that some taste and odour compounds (e.g. geosmin) with low molecular weights similar to the biotoxins mentioned above can pass through pretreatment and reverse osmosis membranes (Reiss et al., 2006). Further, the complete removal of biotoxins is not guaranteed in membranes with micro-fissures caused by, for instance, high pressures within the desalination plant system. Excessive pressures can be caused by the obstruction of intake filters due to high-biomass blooms, such as the ones caused by Cochlodinium polykrikoides that occurred in the Arabian Gulf and Gulf of Oman (Richlen et al., 2010). Still, the data are limited (e.g. Caron et al., 2010; Dixon et al., 2011a, b; Laycock et al., 2012), based mainly on laboratory studies (without the appropriate up-scaling), and there are only a few studies (Seubert et al., 2012) from plants operating during blooms of biotoxin-producing $\mathrm{HAB}$ species. Therefore, more research is needed to ascertain the fate of biotoxins during the desalination process. The potential risk of chronic exposure to biotoxins requires their monitoring in drinking water produced in desalination plants.

\section{HABs and aerosolized biotoxins}

\section{KARENIA BREVIS AND BREVETOXINS}

Over three decades, multi-institutional and multidisciplinary studies in the Gulf of Mexico and along the coast of Florida have explored how the inhalation of aerosols containing brevetoxins during high-biomass, toxic Karenia brevis blooms can cause respiratory symptoms (e.g. Fleming et al., 2005, 2006, 2011). Beach visitors and full-time lifeguards have reported respiratory disorders (Backer et al., 2003, 2005), and studies have shown that people with asthma (and possibly other lung diseases) were particularly at risk from more severe and longer-lasting symptoms (Fleming et al., 2005, 2006, 2011; Milian et al., 2007; Bean et al., 2011). More recent research has modelled the health costs of these effects (Hoagland et al., 2009, 2014).
The results of this research have been used to engage with stakeholders to develop local response management plans to help minimize societal impacts of Karenia blooms on human health (e.g. Kirkpatrick et al., 2010; Fleming et al., 2011; Zhao et al., 2013). Information about the likelihood of health impacts has been used to inform personal decisions as well. For example, the Gulf of Mexico HAB Forecast (see NOAA Harmful Algal Bloom Operational Forecast System (HAB-OFS), https://tidesandcurrents.noaa.gov/hab/, accessed 26 August 2015) in conjunction with a local Beach Condition Reporting System is used by windsurfers and beach visitors to decide, depending on the wind, tides and the presence of a Florida red tide, whether or not to visit a particular beach on a given day. Thus, current observations and forecasts of this HAB may help to protect public health by decreasing exposures to toxic aerosols.

\section{OSTREOPSIS CF. OVATA AND RESPIRATORY}

\section{IRRITATIONS}

Over the past two decades, extensive blooms of Ostreopsis spp. have occurred in the Mediterranean (e.g. Algeria, France, Italy, Tunisia). During these blooms, beach users have experienced upper respiratory disorders (rhinorrhoea), eye and nose irritation, fever and general malaise, and sought medical care in hospital emergency departments and primary healthcare centres (Àlvarez et al., 2005; Gallitelli et al., 2005; Brescianini et al., 2006; Durando et al., 2007; Barroso et al., 2008; Vila et al., 2008, 2012; Tichadou et al., 2010; Tubaro et al., 2011; Illoul et al., 2012). A similar situation could also be occurring in certain beaches in Brazil (Proença et al., 2010). The health effects could be caused by exposures to aerosols containing biotoxins or allergenic substances produced by Ostreopsis cell fragments or accompanying microbiota (Casabianca et al., 2013; Ciminiello et al., 2014). Reported cases of cutaneous irritation were attributed (but not proven) to direct skin contact with seawater containing high concentrations of Ostreopsis cells. At present, studies (including epidemiological and ecological) are underway to improve the understanding of Ostreopsis bloom dynamics and the possible links to human health effects (Vila et al., 2014; Berdalet et al., 2015).

\section{EFFECTS DF HABS DN HUMAN WELLBEING}

In addition to the risks to human health posed by exposure to biotoxins, marine HABs can impact other aspects of human wellbeing, including human commercial and recreational uses of the coastal and marine environments, such as fishing, shellfish collection and growing, and tourism, and non-market, passive uses of the ocean, such as preferences for particular ecological states. Also, marine HABs may lead to complex societal responses in the affected human communities, such as the more general avoidance of coastal and ocean resources due to misconceptions and inadequate communications of health risks. In this section, we refer to the economic effects resulting both from biotoxin producing species (Box 1) and from algal taxa involved in high biomass events (Box 2). Difficulties in developing estimates of the economic costs associated with HABs are considered in detail in this section. 
Box 2. Representative examples of HABs that affect marine organisms or ecosystems, with effects on wellbeing, and on human health in some cases.

Events presented following the alphabetical order of the Causative organism ( $\underline{\mathrm{CO}})$. The Type $(\underline{\mathrm{T}})$ of bloom, their Effect/mode of action in the marine organisms or ecosystem (E/m-a), Effects on humans (E-h), Main Geographic Affected Areas ( $\underline{\mathrm{A}})$ and some References $(\underline{\mathrm{R}})$ are indicated.

General information. Certain $\mathrm{HABs}$ affect marine organisms and ecosystems, due to the accumulation of biomass of particular taxa, which may or may not produce biotoxins In most cases, fish-killing HAB species produce haemolytic or cytotoxic biotoxins, which cause necrotizing degeneration of the fish gills. Other, more rare or more recently discovered combinations of fishkilling algae and their biotoxins include goniodomins (produced by G. pseudogonyaulax), amphidinols (synthesized by Amphidinium klebsii and A. carteri; reviewed by Louzao et al., 2014) and karlotoxins from Karlodinium spp. (Bachvaroff et al., 2008; Place et al., 2014; Van Wagoner et al., 2010). In many cases though, the toxic compound has not yet been clearly identified.

The breakdown of cells during the decline of a bloom, with the subsequent degradation and utilization of the organic matter by bacteria can result in low oxygen concentrations of isolated bottom water, causing subsequent macrofauna mortalities. Other impacts on the ecosystem include: the reduction of light penetration, production of excess ammonia, physical damage of fish gills, and hypothermia in marine birds due to the accumulation of surfactant-like proteins Here we list examples of many microalgae and a macrophyte involved in $\mathrm{HAB}$ events. More details and examples of these blooms, mainly high biomass blooms, can be found, among others, in e.g. GEOHAB, 2001, 2006, 2010 (download free from http:// www.geohab.info).

\section{CO: Akashiwo sanguinea (Dinophyceae)}

T: High biomass, non-toxic

E/m-a: Extensive marine birds mortality caused by hypothermia. The microalgae produced high amounts of organic matter that accumulated at the sea surface. The foam contained surfactant-like proteins, which destroyed the waterproof and insulation characteristics of the bird feathers

E-h: Unknown

R: Jessup et al. (2009)

A : Pacific North-west (Monterey Bay, California)

CO: Chaetoceros wighami, C. debile (Bacillariophyceae); Dictyocha speculum (Silicoflagellate) T: High biomass, nontoxic. Physical damage (silicic cell cover) of the fills gills E/ m-a: Farmed fish kills

E-h: Economic losses (several million pounds)

R: Bruno et al. (1989); Treasurer et al. (2003)

A : Europe (Loch Torridon, Scotland; Shetland Isles)

CO: Chattonella antiqua and C. marina (Raphidophyceae)

T: High biomass, toxic (haemolytic, haemagglutinating and neurotoxic effects, molecule similar to brevetoxin)

E/m-a: Aquaculture fish and natural fauna kills

E-h: Economic losses (US\$0.5 billion in 1972; Australia
AU \$45.o million losss of caged bluefin tuna in April 1996)

R: Endo et al. (1985), Marshall \& Hallegraeff (1999), and references cited therein

A: Japan, Australia, India, Florida and China

CO: Cochlodinium polykrikoides, Cochlodinium spp. (Dinophyceae)

T: High biomass, toxic. The toxic compound and mechanism have not been identified yet, with controversial results (Tang \& Gobler, 2008, and refs therein). Toxicity could be caused by non-hydrogen peroxide, highly reactive, labile biotoxins such as ROS-like chemicals

E/m-a: Wild and farmed fish kills; coral and shellfish

E-h: Economic losses. Hundreds of millions of US\$ in fisheries losses in Korea alone; more than US\$3.0 million in Vancouver (in 1999); in the Arabian Gulf and Gulf of Oman, the long-lasting Cochlodinium bloom of 2010 killed thousands of tonnes of fish, limited traditional fishery operations, damaged coral reefs, impacting coastal tourism, and forcing the closure of desalination systems

R: Yuki \& Yoshimatsu (1989); Kim et al. (1999); Whyte et al. (2001); Gobler et al. (2008); Richlen et al. (2010); Kudela \& Gobler (2012), and references cited therein

A: North America, Asia, Australia and Europe

CO: Heterosigma akashiwo (Raphidophyceae)

T: High biomass, toxic. No identified toxic nor toxicity mechanism, which may affect other aquatic organisms (zooplankton, copepods, benthic larvae)

E/m-a: Aquaculture fish kills

E-h: Economic losses

R: Black et al. (1991), Yamochi (1989); MacKenzie (1991); Powers et al. (2015)

A: Atlantic and Pacific coast: Canada, Chile, Japan and New Zealand

CO: Karenia brevis (Dinophyceae)

T: High biomass, toxic (brevetoxin, haemolytic)

E/m-a: Toxicity to humans and marine fauna by direct ingestion or aerosolization; manatee mortality during the active bloom phase; dolphin and manatee poisoning and mortality through the ingestion of contaminated fish and aquatic plants during the senescence phase of the bloom. Fish kills

E-h: Health costs; tourism losses, passive use losses; costs of beach cleanups

R: Tangen (1977); Steidinger et al. (1998); Bossart et al. (2002); Magaña et al. (2003); Flewelling et al. (2005); Naar et al. (2007); Campbell et al. (2013)

A: Gulf of Mexico, Florida, North Carolina

CO: Karenia mikimotoi (Dinophyceae)

T: High biomass, toxic (gimnocin, haemolytic)

$\overline{\mathrm{E}} / \mathrm{m}-\mathrm{a}$ : Fish kills. Mortalities of marine fauna

E-h: Economic losses; passive use losses

R: Dahl \& Tangen (1990, 1993); Nakamura et al. (1995); Gentien (1998); Raine et al. (2001); Satake et al. (2002); Silke et al. (2005); Vanhoutte et al. (2008); Davidson et al. (2009) A: Asian and Australian, Northern European waters

CO: Noctiluca (heterotrophic Dinophyceae)

T: High biomass, non-toxic 
E/m-a: Hypoxia and excess ammonia in the environment; unpleasant odours; water discolouration

E-h: Economic losses (on tourism, not estimated)

R: Bricelj \& Lonsdale (1997); Elbrächter \& Qi (1998); Murray \& Suthers (1999); Fonda-Umani et al. (2004) A: Worldwide

CO: Ostreopsis cf. ovata, O. siamensis (benthic Dinophyceae)

T: High biomass, toxic

E/m-a: Cells attach to corals, macrophytes or macrofauna by mucous substances. Toxicity (Palytoxin and analogues) to marine fauna by direct ingestion or by anoxia. The particular mechanisms have not been identified yet

E-h: Respiratory irritation, possible gastrointestinal illness

R: Shears \& Ross (2009); Mangialajo et al. (2011) and references cited therein

A: Mediterranean, New Zealand, Brazil, Japan

\section{CO: Phaeocystis (Prymnesiophyceae)}

T: High biomass, non-toxic

E/m-a: Production of foam or mucilage (alteration of gas diffusion and rheologic properties) causing farmed fish kills; discolouration and repellent odour can impact tourism

E-h: From $\sim$ US\$0.7 million in Vietnam to $\sim$ US\$7.5 million in Asian aquaculture (1997, Quanzhan Bay, Fujian province, China)

R: Lancelot et al. (1987); Schoemann et al. (2005); Hai et al. (2010) and references cited therein; Arin et al. (2013)

A: Asian coastlines, North Sea, Antarctica

\section{CO: Prymnesium parvum (Prymnesiophyte)}

T: High biomass, toxic. A variety of toxic compounds with lytic effects (allelopathy) that would affect other organisms in the food webs, as well as haemolytic and cytotoxic effects on fishes (Blossom et al., 2014)

E/m-a: Aquaculture fish kills

E-h: Economic losses (US\$5.0 million)

R: Kaartvedt et al. (1991)

A: Norwegian fjords

CO: Pseudochattonella verruculosa (Dictyochophyceae)

T: High biomass, toxic

$\overline{\mathrm{E}} / \mathrm{m}-\mathrm{a}$ : Aquaculture fish kills

E-h: Economic losses

R: Mackenzie et al. (2011)

A: New Zealand

\section{CO: Pseudo-nitzschia spp. (Bacillariophyceae)}

T: High biomass, toxic (domoic acid, neurotoxic)

$\overline{\mathrm{E}} / \mathrm{m}-\mathrm{a}$ : Morbidity and mortality of large vertebrates, including seabirds, sea lions, sea otters, selas, and possibly whales

E-h: Possible passive use losses

R: Sierra-Beltrán et al. (1997); Scholin et al. (2000); Hall \& Frame (2010)

A: Especially, Pacific coast of North America

CO: Ulva (Ulvaceae), macroscopic benthic macroalgae

T: High biomass, non toxic

E/m-a: Hypoxia in the environment; unpleasant odours; impacts on tourism
E-h: Beach cleanup costs: US\$87.3 million in China; US\$10.3-165.9 million in France, depending on the extent of affected areas (approximate period 1989-2006)

R: Hu \& He (2008); Zhou et al. 2015 and references cited therein.

A: China (Qingdao) during the Olympics, Atlantic French coast

In China, disrupted activities during the Olympic games in 2008

\section{Economic effects of HABs linked to food security and seafood-related activities}

Certain HABs constitute a threat to aquaculture food production, which has become a major source of protein (linked to decreasing wild fish stocks) for expanding human populations, particularly in coastal communities in developing countries. Like farming, and sometimes in conjunction with it, aquaculture helps to support many local and regional economies (FAO, 2006). Currently, and with respect to the cultivation (and wild-harvest) of shellfish, the most effective way to protect humans from HAB-related seafood poisoning is to monitor for the presence of $\mathrm{HAB}$ species or biotoxins and to enforce periodic closures of commercial and recreational harvesting or growing areas (Figure 3). Contamination of seafood products can result in economic losses in shellfish collection and growing, and in the aquaculture of certain finfish. There may also be losses in ancillary industries, including processing, distribution, wholesaling and retailing of seafood (Larkin \& Adams, 2007; Morgan et al., 2010).

Estimating the overall economic costs associated with the occurrence of HABs is complex. These costs vary markedly, depending on geographic region, seafood product, the frequency and intensity of HAB-related events, the duration of fishery closures and the costs of healthcare provision. As an example, Hoagland et al. (2002) estimated the annual economic effects of HABs in the USA between 1987 and 1992. At that time, the economic effects were valued in the order of US\$50.0 million per year; this calculation has been subsequently adjusted for inflation to $\sim$ US $\$ 100.0$ million per year (Hoagland \& Scatasta, 2006). It is important to note that there is considerable variation in estimated impacts from year to year. This estimate was based on a compilation of the assessments of economic effects in public health, commercial fisheries, recreation and tourism, and monitoring and management. Notably, public health effects are the largest component, representing about $42 \%$ of nationwide average effects during that time period. Although the actual incidence of ciguatera fish poisoning (CFP) is very uncertain in many tropical locations, estimates of CFP illnesses comprise $99 \%$ of the total public health costs.

With regards to the specific economic costs of HAB-induced illnesses, there are very few studies available. The UNEP Global Environmental Outlook lists the worldwide economic impacts of algal biotoxins on human health from seafood alone as $\sim$ US $\$ 4$.o billion a year (GESAMP, 2001). As a comparison, the impact of infectious hepatitis from seafood consumption was estimated to be $\sim$ US\$7.2 billion per year. The direct medical care costs associated with the respiratory and digestive illnesses caused by K. brevis blooms along the Florida coast of 
the Gulf of Mexico ranged from US\$0.1 - 0.7 million annually, depending on the intensity of the event (Hoagland et al., 2009, 2014). Illness costs might exceed US $\$ 1.0$ million per year for large, long-lasting blooms, however, such as one that occurred during 2005-06. Assuming that the average annual illness costs of $K$. brevis blooms would persist into the future, using a discount rate of $3 \%$, the capitalized costs of future illnesses would range between US\$2.0-24.0 million.

In the particular case of ciguatera fish poisoning, the average medical costs of diagnosis and treatment in traditionally non-endemic areas, as for instance in Canada, was estimated at about CA $\$ 2470$ per case, with about 1000 cases per year related to tourism and food importation in 1990 (Lange et al., 1992; Todd, 1995; Fleming et al., 2002). Accurate estimates of the human costs of these diseases necessitate an adequate knowledge of their prevalence and incidence, as well as an understanding of their acute and chronic human health effects (Pennotti et al., 2013).

Any estimation of the economic effects of HABs also should include an evaluation of the costs of monitoring and management, which would include, for instance, sampling programmes or strategies to decrease the risk of $\mathrm{HAB}$ occurrences (e.g. reducing coastal eutrophication, sustainable use of the coastal zone, and other human-related activities) or their impacts (Hoagland et al., 2002). For instance, limiting shellfish harvesting closures or varying the timing of shellfish or finfish harvesting could be useful strategies to reduce the impacts of HABs, but these actions also may have associated costs in terms of product marketability. Wessells et al. (1995) found that the occurrence of paralytic shellfish poisoning in blue mussels from the Canadian maritimes, leading to illnesses and subsequent harvest closures, adversely affected the market for mussels from Maine. Whitehead et al. (2003) found that, after consumer demand for seafood contracted upon learning of a HAB-induced fish kill, mandatory seafood inspection programmes were more effective in restoring consumer confidence and expanding demand than broad public assurances of seafood safety.

Experience suggests that closure strategies in shellfish production areas could be beneficial over the long term, despite leading to losses in the short term. For example, this approach has been applied recently in the northern areas of Hokkaido and Tohoku (Japan) with some benefits. The region provides more than the $60 \%$ of the scallop aquaculture in Japan, accounting for about 500 thousand tonnes per year with a value of $\sim$ JPY84.o billion ( US\$700.o million USD). Paralytic and diarrhetic shellfish poisoning events had caused the complete closure of shellfish harvesting in the 1980s, resulting in dramatic economic impacts (Imai et al., 2014). Another example is from the Galician region of NW Spain. The Rías are a highly productive ecosystem that sustain a production of $0.2-0.3$ million tonnes of mussels (Mytilus edulis) per year. Bans on harvesting can last up to 9 months (particularly in Dinophysis bloom hotspot areas), when DSP biotoxin levels exceed European Union regulatory thresholds (e.g. Blanco et al., 2013). NW Europe has the highest incidence of diarrhetic shellfish poisoning (DSP) in the world, and intensive monitoring of biotoxins attempts to ensure that any closures of shellfish harvesting are limited to the minimum time needed.

Some data about the economic losses caused by ichthyotoxic $\mathrm{HAB}$ species in aquaculture are shown in Box 2. In most cases, fish-killing HAB species (e.g. Karenia mikimotoi, K. brevis, Prymnesium spp., Chattonella spp.) produce biotoxins with neurotoxic, haemolytic or cytotoxic effects on fishes. Some HAB species have been linked directly to massive fish kills, often at aquaculture sites. In 2003, losses in European coastal waters were estimated at more than $€ 800$ million in fisheries associated with HABs (Scatasta et al., 2003; note that these are global data, including finfish and shellfish wild harvests and aquaculture). Analogous losses in the USA were conservatively estimated at around US\$4.0 million annually, adjusted for inflation (Hoagland et al., 2002). Kim (2006) reported HAB-related aquaculture losses in Japan of more than US $\$ 1.0$ billion annually. Recent estimates were presented at the PICES (North Pacific Science Organization) 'Workshop on Economic Impacts of Harmful Algal Blooms and Aquaculture' (Trainer \& Yoshida, 2014). From 2006 to 2012, the total economic losses in farmed fish and shellfish production was estimated as $\sim$ US\$94.0 million for Korea, Japan and China. Note that many of these estimates are lost sales (gross revenues); they should be regarded as over-estimates of true economic losses because they do not account for the avoided costs of not fishing. Where commercial wild harvest fisheries are managed inadequately and therefore economically or biologically over-exploited (a common occurrence), lost net economic values, representing actual declines in human welfare, are likely to be a small fraction of reported lost sales.

There may be special impacts of high biomass HABs on the operation of desalination plants, which would result in the disruption of water production and significant economic losses. For instance, in 2008 and 2009, at least five seawater desalination plants were closed in the United Arab Emirates (UAE) due to a dense bloom of the ichthyotoxic Cochlodinium polykrikoides in the Arabian Gulf and Gulf of Oman that lasted for more than 8 months (Richlen et al., 2010; Anderson \& McCarthy, 2012). In this particular case, algal biomass clogged the filtration systems and reverse osmosis membranes.

\section{Impacts of HABs on non-market, passive use values of marine ecosystems}

Certain HABs have noxious, even lethal, consequences on marine organisms and ecosystems (Box 2), thereby potentially leading to passive value losses or the degradation of ecosystem services.

Some taxa produce particular toxic compounds that, given their high concentrations in the water when the species bloom, have been involved in mass mortalities of wild fauna. According to the US National Oceanic and Atmospheric Administration (NOAA), more than $50 \%$ of all Unusual Mortality Events (UMEs) of wild animals (turtles, dolphins, manatees, whales, birds; e.g. Scholin et al., 2000), could have been due to microalgal biotoxins, although it is evident that this is not a new phenomenon and is also a part of the natural ecosystem functioning. There are reports of mortalities of wild fish associated with HABs that date back to the latter part of the 19th century (Whitelegge, 1891). In 1968, mortalities of sand eels (Ammodytes spp.) and an estimated $80 \%$ of the breeding population of shag (Phalacrocorax aristotelis) coincided with a bloom of Alexandrium tamarense off the north-east coast of the UK (Adams et al., 1968; Coulson et al., 1968). White (1984) documented four cases of fish kills associated with saxitoxins. Other historical examples include the deaths of 19 humpback whales off Cape Cod 
(USA), and probably the deaths of pygmy, dwarf sperm and North Atlantic right whales in the same region, as well as Southern right whale mortalities in Peninsula Valdés (Argentina). More recently, Scholin et al. (2000) reported the deaths of over 400 California sea lions (Zalophus californianus) along the central Californian coast during May and June 1998. Coincident with these mortalities, a bloom of Pseudo-nitzschia australis was reported and domoic acid was detected in planktivorous fish and in sea lion body fluids.

Jessup et al. (2009) reported extensive marine bird mortality in the Pacific North-west (Monterey Bay, California) in winter 2007 coinciding with a bloom of the non-toxic dinoflagellate Akashiwo sanguinea. Affected birds had a slimy yellowgreen material on their feathers, and they were diagnosed as severely hypothermic. This dinoflagellate excretes high amounts of organic matter that accumulate at the sea surface. In this case, the sea foam contained surfactant-like proteins, which destroyed the waterproofing and insulative characteristics of the bird feathers.

Ostreopsis blooms constitute a particular case of an emerging harmful event that is a growing problem in coastal environments. Since the end of the 2oth century in temperate waters (e.g. in the Mediterranean, Brazilian and New Zealand coasts), blooms of this benthic dinoflagellate genus have been linked to damage to marine fauna (i.e. mussel mortalities, loss of spines and death of sea urchins, loss of one or more arms in sea stars, and coral bleaching) and subsequent alterations of the coastal ecosystems (Sansoni et al., 2003; Simoni et al., 2003; Shears \& Ross, 2009). In some cases, the invertebrate community of the affected area has not recovered to date (Vila et al., 2012). Coinciding with these effects, high cell concentrations of $O$. cf. ovata (mainly in the Mediterranean) or O. siamensis (mainly in New Zealand) were recorded in the water column. Also, highly visible distinctive rusty-brown coloured mucilaginous films covered the reef, macroalgae and other sedentary organisms, or floated in the water column or on the surface. Oxygen depletion seems to be the most likely cause of the observed effects. Direct toxicity to the fauna (via ingestion of Ostreopsis through the food web) cannot be ruled out, given that palytoxin analogues (i.e. ostreocin and ovatoxin) have been isolated from certain macrofauna at other Mediterranean sites (Aligizaki et al., 2008, 2011; Amzil et al., 2012; Biré et al., 2013).

High-biomass Phaeocystis blooms also have been linked to the deterioration of water quality in some coastal regions of the North Atlantic and the Mediterranean (e.g. Lancelot \& Mathot, 1987; Arin et al., 2013). This species produces macroscopic colonies embedded into a mucilaginous matrix. The decay of the blooms results in brownish foams containing 3-dimethylsulphoniopropionate (DMSP), which is responsible for bad odours (Liss et al., 1994). Although this may result indirectly in the loss of recreational activities, no economic assessment has been undertaken yet, and no direct harm to humans has been reported.

Finally, some studies have suggested that certain $\mathrm{HAB}$ species also could have subtle impacts on ecosystems, by altering fundamental physiological and biological processes (e.g. feeding behaviour, life stages, survival strategies, reproductive capacity) in other organisms of food webs, likely through allopathic effects (e.g. Fistarol et al., 2003; Tillmann, 2003; Granéli \& Hansen, 2006). These particular effects are not easy to detect, however, and the underlying mechanisms of damage to other components of the food webs remain difficult to understand (Landsberg, 2002; Shumway et al., 2003). This is due, in part, to the spatial and temporal variability of $\mathrm{HAB}$ events and also to the difficulty of isolating their impacts from those associated with other environmental and/or anthropogenic factors (e.g. increased temperature, wave action, habitat destruction). Both long-term field studies and experimental approaches in the laboratory are required to ascertain the direct and indirect impacts of HABs in the different components of the ecosystems.

\section{The challenges of estimating the economic costs of HABs}

As explained, HABs can lead to economic losses associated with the costs of treating human illnesses, closures of commercial and recreational shellfisheries, mortalities of fish in commercial finfish aquaculture operations, declines in coastal recreation and tourism, and additional investments in environmental monitoring and the prevention, control or mitigation of blooms or their consequences (Hoagland et al., 2002). Hoagland \& Scatasta (2006) estimated economic effects (adjusted for inflation into 2015 US\$) in the order of US $\$ 1.0$ billion per year in Europe and US\$100.0 million per year in the United States. The European estimate was influenced largely by estimated losses to coastal tourism, which is affected mostly by high biomass, noxious (blooms causing high foam volumes, discolouration of the ocean, noxious odours, or beach closings), but not necessarily toxic, HABs. Any estimates of the scale of the economic effects of HABs should be considered very rough approximations, even in areas where they have been relatively well studied, including the USA and Europe. Estimates in other parts of the world, particularly in developing countries, are much more speculative and uncertain. The development of comprehensive and consistent estimates of losses in economic welfare as a consequence of HABs remains a clear priority for future research.

The reasons why economic estimates often are uncertain include the wide variety of methodologies used to compile the assessments, some of which produce estimates of economic measures that may not be strictly comparable (e.g. sales, indirect or induced impacts, consumer or producer surpluses, agency budgets); the wide variety of physical and economic effects; the episodic and often unpredictable nature of blooms of different types in many areas; and the wide ranges of responses of humans to mitigate the adverse impacts, including, most importantly, switching to next-best alternative activities or foods. Moreover, these reasons tend to be context-dependent, because of differences in the capabilities of human communities for responding to HABs as a natural hazard. For example, shellfish management measures are well-practiced in many parts of the developed world, such as in Maine or Florida in the USA, but often non-existent or difficult to enforce in parts of the developing world, such as in the coastal bays of the Bohol and Visayan Seas in the Philippines. Morbidities and mortalities from shellfish poisonings, particularly among the underprivileged, are common in the latter but now exceedingly rare in the former (but see Reich et al. (2015) for a modern counter-example of neurotoxic shellfish poisonings from Florida).

Other so-called non-market, 'passive' uses of the coastal and marine ecosystems, such as for the conservation of protected species (including marine mammals and sea turtles), 
can in theory be affected by HABs. Even if favoured species or unique ecosystems are not used directly, humans may experience a sense of loss that might be evaluated in economic terms. Studies of passive value losses due to the adverse effects of HABs on protected species or ecosystems are almost nonexistent. One reason for the lack of estimates of effects on passive use values is that, although individuals may become ill or die as a consequence of HABs, such as the deaths of endangered West Indian manatees (Trichechus manatus) due to Karenia brevis blooms in south-western Florida, the populations often are largely unaffected by the mortalities (in essence, K. brevis blooms could be viewed as one of many natural sources of mortality). Similarly, the media often report on 'large-scale' finfish kills resulting from HABs, but the impacts on fish biomass and the growth rates of fish stocks in the wild often are minor or imperceptible.

Of greater concern to users of coastal and marine ecosystems is the loss of access to commercial or recreational fisheries, especially to high-valued shellfish stocks, such as oysters, scallops, clams, mussels, crabs, or marine snails, or to areas used to grow shellfish. Even in such cases, commercial fishermen (a market-based, direct use) tend to relocate or to switch fisheries or occupations, thereby mitigating substantial economic losses. Recreational fishermen (a non-market, direct use) choose another target or another pastime. Further, seafood consumers also can switch among food options. When switching occurs, other fisheries, recreational destinations, or food providers may benefit. Because the latter typically are not 'first-best' choices, economic losses are ipso facto incurred in all cases, but the human behavioural switching response clearly serves to blunt the impacts. Here, policies to improve the communication of risks, say through the widespread publication of the locations of closures or the species affected, which facilitates human switching, also may help significantly to mitigate economic losses. Finally, shellfish rarely are adversely affected by blooms, and one consequence of this 'immunity' to biotoxins is that areas closed to shellfish harvesting may become de facto fishery reserves, helping to conserve stocks, provided that the biotoxin is naturally metabolized or lost after the bloom disappears.

\section{Social impacts of the health risks caused by toxic HABs. The case of ciguatera fish poisoning}

Within the human communities whose revenue is based on aquaculture and shellfish activities, HABs may have adverse social impacts including damaged reputations, decreased incomes, employment losses, and longer-term changes in seafood consumption patterns (Magnien, 2001). There has been very little study of these other human dimensions, and many social impacts remain mostly conjectural and unexplored (Bauer et al., 2009).

In the case of the ciguatera fish poisoning (CFP), it has been associated with the loss of a traditional food source, losses in commercial fishing businesses, losses of tourism, increased costs of medical care, and high costs of monitoring and management (Epstein \& Rapport, 1996). Fear of CFP can lead to reduced fishing in coral lagoons (Dewailly et al., 2008), and to a corresponding increased reliance on pelagic fish or on a less healthy diet of lower quality, imported, canned fish or red meat. This new diet, combined with reduced levels of physical exercise, may be one factor contributing to the trend of increasing obesity among Pacific Islanders, accompanied by a rising prevalence of chronic diseases (e.g. diabetes, hypertension and cardiovascular diseases) in indigenous Pacific populations (Lewis \& Ruff, 1993).

Ciguatera fish poisoning outbreaks could harm the economies of tropical islands, many of which are highly dependent on local reef fisheries for subsistence, export products, and tourism. Reduced fishing effort due to endemic ciguatera has been blamed for losses of traditional fishing knowledge, as new generations abandon artisanal or commercial fishing. One example concerns Rarotonga, an island located in the southern Cook Islands that exhibits the world's highest incidence of ciguatera poisoning. On Rarotonga, the per-capita fresh fish consumption decreased from $149 \mathrm{~g} \mathrm{~d}^{-1}$ in 1989 to $75 \mathrm{~g} \mathrm{~d}^{-1}$ in 2006, due to concerns about CFP (Rongo \& van Woesik, 2012). Consequently, over the same period, the consumption of alternative proteins, particularly imported meats, increased. The direct loss in value of marketable goods from commercial fisheries amounted to NZ\$o.8 million (about US\$0.5 million) per year, and the approximate costs associated with dietary shifts amounted to NZ\$1.0 million (about US\$0.7 million) per year. With a decline in cases of ciguatera poisoning in recent years, fresh fish has returned to the menus of Rarotongans, and per-capita fresh fish consumption increased to $104 \mathrm{~g} \mathrm{~d}^{-1}$ in 2011.

In a discussion of the effects of HABs on public health, it should be highlighted that the management of tropical waters for ciguatera fish poisoning is not well-developed. In these regions, fishermen usually are able to continue to access areas where finfish may have bioaccumulated ciguatoxin, leading to circumstances in which CFP illnesses may become widespread. Given that, researchers and managers may wish to prioritize characterizing the extent of the CFP problem in tropical regions and developing ways to alleviate it.

\section{PRESENT AND FUTURE CHALLENGES, STRATEGIES AND OPPORTUNITIES}

HABs are natural phenomena that have almost certainly occurred for thousands of years before recorded history (Mudie et al., 2002). To humans, HABs constitute a problem worldwide, but the idea that HABs might be prevented from occurring is not a viable option. However, improvements in our understanding of $\mathrm{HAB}$ dynamics during the last 40 years have led to insights for designing strategies to mitigate their impacts. Successful strategies consider the present situation and the future prospects of the potential spread and increase in $\mathrm{HAB}$ occurrence as a result of climate and other environmental changes. Common strategies can be adapted to address specific, local problems in different parts of our world. Despite some limitations, new advances in technology and coordinated international research efforts may help to improve the management of the impacts of HABs.

\section{Improving monitoring and research needs to forecast and predict $\mathrm{HAB}$ events}

Monitoring programmes for $\mathrm{HAB}$ species and their toxins implemented in different areas of the world have clearly 
reduced fatal poisonings in humans (e.g. Davidson \& Bresnan, 2009). For example, current monitoring programmes of the European Union are driven by its Food Hygiene Regulations (EC) No. 853/2004 and (EC) No. 854/2004, which require Member States to monitor both for biotoxin concentrations in shellfish tissues and the presence of marine biotoxinproducing phytoplankton in coastal waters. Due to different capacities for undertaking local risk assessments, there are local differences in the implementation of these monitoring activities. In general, these programmes have been successful in safeguarding human health, but continued refinement will be needed in the future as environmental conditions shift (particularly climate warming) and human uses of the coastal ocean change.

Currently missing are programmes of robust monitoring in developing countries where they are often at best rudimentary, despite increasing exports of seafood products to other regions (Reich et al., 2015). Despite their success, established monitoring programmes are not without technical, logistical or costrelated limitations (DeGrasse \& Martinez-Diaz, 2012; Hess, 2012; Suzuki \& Watanabe, 2012). Since their inception, improvements have been linked to advances in technologies related to sampling, taxonomic and biotoxin analyses, and observing systems.

Light microscopy constitutes the most widespread monitoring tool for harmful algal species, but it is time consuming to employ, and it requires specialized training and expertise. Development of quantitative biomolecular tools to facilitate monitoring could improve monitoring. Given the number of different organisms that have to be tracked, and the lack of fully quantitative molecular tools for their enumeration, monitoring agencies cannot currently replace light microscopy as the primary tool. Maintaining and supporting the training of microscopists in the identification and quantification of HABs species is necessary for successful monitoring.

While the ability to detect the presence of harmful microalgal species in coastal waters can provide an excellent early warning of the likely occurrence of biotoxins in, for example, shellfish (e.g. Trainer \& Suddleson, 2005), many uncertainties remain. These include the fact that the presence of potentially toxic organisms is not always linked to toxicity in shellfish. For example, in Scottish waters, morphologically indistinguishable toxic and non-toxic Alexandrium tamarense cells have been known to occur simultaneously (Touzet et al., 2010). Furthermore, known-toxic organisms are not always detected efficiently due to their benthic character, fragility when preserved, or small size. For example, the azaspiracid producer Azadinium spinosum measures only $7 \times 12 \mu \mathrm{m}$. The link with its produced biotoxin was established recently in 2007 (Tillmann et al., 2009), only after standards for biotoxin analysis were isolated (Satake et al., 2002; Jauffrais et al., 2012; Kilcoyne et al., 2012) and biomolecular tools for tracking the organism in water were developed (Kilcoyne et al., 2014). Further, toxicity itself is not always well described. For example, not all of the biotoxins of many Gambierdiscus species have been described, and they may be present in complex mixtures in different individual organisms and blooms. Finally, toxicity may be associated with new, unexpected vectors or species. For example, in 2002, the consumption of puffer fish from Florida caused neurological disease in 21 people (Centers for Disease Control and Prevention (CDCP), 2002). Initially, based on patient symptoms and reported puffer fish ingestion, the outbreak was attributed to tetrodotoxin. A mouse bioassay confirmed the presence of a $\mathrm{Na}+$ channel blocking toxin, tentatively identified as tetrodotoxin (usually associated with puffer fish), in unconsumed portions of fish. Direct measurement analyses (LC/MS, immunoassay, and receptor binding assay) confirmed the unexpected presence of saxitoxin in the fish samples, however, but not tetrodotoxin. Analysis of urine samples from the victims of the outbreak confirmed these findings. This was the first confirmed report of saxitoxin poisoning associated with puffer fish ingestion in North America (Landsberg et al., 2006).

Concerning biotoxin detection, bioassays (i.e. the mouse bioassay) had been used traditionally as a fast way to detect the presence of toxins in potentially contaminated seafood, thus raising warnings and preventing the harvest of contaminated shellfish. Bioassays are associated with a number of technical and ethical issues (Hess et al., 2006), however, and led to their recent replacement with non-animal alternatives (i.e. cell tissue cultures; e.g. Van Dolah et al., 2012) in many countries, particularly in Europe (European Commission, 2011). Research efforts are now focused on the development of multi-toxin methods for the detection of multiple groups of compounds in biosensor systems (Campbell et al., 2014, and references cited therein). The large number of compounds that need to be detected and an inability to validate new tools for detection mean that many monitoring agencies will need to continue to rely on either insensitive (and ethically questionable) mouse bioassays or on comparatively complex and expensive LC-MS/MS detection methods, neither of which can be implemented in situ.

A potentially useful sampling technique based on the passive capture of biotoxins by resins was developed by MacKenzie et al. (2004). This method has been used successfully to trace biotoxins when the producing organisms are difficult to monitor due to their small size (e.g. Azadinium spp.) or their benthic habit (e.g. Prorocentrum lima and Vulcanodinium rugosum; Fux et al., 2009; Zendong et al., 2014). The technique has not been standardized, however, and it will need further development for hydrophilic biotoxins. At present, the passive capture of biotoxins cannot easily be automated or adapted for in situ detection. Furthermore, ongoing refinement of its analytical methods will be required to meet the challenges of emerging biotoxins (Turner et al., 2015).

Issues arise with the existing technologies with the frequency of representative sampling of in situ biotoxins and the toxin-producing microalgae, which rarely takes place more than weekly, although higher frequency sampling may be desirable in some coastal waters. In the particular case of the benthic harmful species (e.g. Gambierdiscus, Ostreopsis, Prorocentrum lima), sampling techniques require refinements and standardization (e.g. Tester et al., 2014). As yet automated, reliable, and affordable systems to detect harmful species or their biotoxins for routine monitoring in situ are lacking. While recently some promising techniques have been developed to detect biotoxin-producing organisms (e.g. Hess et al., 2012 and references cited therein; ICES, 2015), they are still viewed mainly as research tools and have seldom been used in high frequency in situ monitoring. This is the case of the Environmental Sample Processor (ESP; Greenfield et al., 2008; Scholin et al., 2009) and the Imaging Flow Cytobot (IFCB; Olson \& Sosik, 2007), two automated 
in situ monitoring platforms deployed in Monterey Bay, the Gulf of Maine, Puget Sound and the Gulf of Mexico. The ESP collects and processes water samples in situ, using sensitive and specific molecular assays to detect target HAB cells and toxins, and transmitting the data to the laboratory in near real time. The IFCB is an imaging flow cytometer that captures the high-resolution images and fluorescence characteristics of all plankton cells (in the 5-150 $\mu \mathrm{m}$ size range) at a high frequency ( 3 samples per hour); the data can also be sent to a laboratory in near real time (e.g. Campbell et al., 2010, 2013). At present, however, they have very high costs and cannot be deployed to monitor individual shellfish production areas. Although they cannot replace more traditional forms of monitoring at present efforts are being made to facilitate their use for this purpose. Fortunately, these sophisticated systems are useful tools for advancing an understanding of the links between HABs and ocean dynamics.

The adoption of monitoring technologies are affected strongly by economic costs (Frolov et al., 2013). Some systems are relatively simple, comprising microscopic analysis of water samples for particular HAB species and analysis of shellfish tissues for the presence of biotoxins. Other programmes involve in situ monitoring of phytoplankton and model-based forecasts of bloom occurrence, such those carried out in the Gulf of Maine (e.g. Anderson et al., 2005a, b; McGillicuddy et al., 2005; http://www.whoi.edu/ main/topic/harmful-algae-red-tides) or in California Bay (e.g. Ryan et al., 2005, 2011). According to Bernard et al. (2014), the costs of monitoring could be on the order of 1 billion USD annually, accounting for $10 \%$ of the overall costs of HABs worldwide, estimated to be at 10 billion USD annually for marine and fresh waters. A monitoring system including satellite observations could be made more efficient by improving international cooperation in the collection, interpretation and sharing of Earth observation information, as conceived by the Global Earth Observation System of Systems (GEOSS, Fritz et al., 2008).

Monitoring, combined with operational oceanography and modelling, offers the hope of providing forecasts and early warnings and ultimately predictions of $\mathrm{HAB}$ events (e.g. GEOHAB, 2011; Davidson, 2014). Achieving a predictive capability would require an adequate understanding of the ecophysiology of $\mathrm{HAB}$ species and the physical and chemical processes that influence the occurrence of the blooms, however. One problem is that, in many contexts, such as remote sensing from satellites, $\mathrm{HAB}$ species do not exhibit characteristics that distinguish them from other phytoplankters. Our understanding of the many different processes (biological, ecological, physical, chemical, meteorological) that control $\mathrm{HAB}$ dynamics and the dynamics of microalgae in general is incomplete, making their parameterization in numerical models extremely difficult. To date, progress has been constrained by the complexities of biological interactions and the resulting difficulties in developing ecological models. One example is the $\mathrm{HAB}$ operational forecast (HAB-OFS) developed by NOAA for Florida and Texas (Stumpf et al., 2008; http://tidesandcurrents.noaa.gov/hab/). HAB-OFS combines satellite imagery, field observations, models, public health reports and buoy data to help forecast $K$. brevis blooms. Another NOAA effort for forecasting Pseudo-nitzschia has incorporated input from stakeholder communities in the state of Washington (Brown et al., 2012). In the Gulf of
Maine, a coupled physical/biological model (e.g. He et al., 2008) predicts the transport of Alexandrium fundyense cells, controlled by plume advection and wind forcing. Statistically based models (Anderson et al., 2009; Lane et al., 2009) have successfully hindcast Pseudo-nitzschia blooms in Monterey Bay and Chesapeake Bay. Finally, conceptual models, such as for Phaeocystis blooms in Vietnam (Hai et al., 2010) and Dinophysis acuminata (Velo-Suárez et al., 2014) in the Rías of north-western Spain, have provided new insights into understanding the dynamics of blooms and designing preventive strategies.

Sustained fundamental research could help generate a better understanding of $\mathrm{HAB}$ dynamics, to inform and improve monitoring programmes, and to design methods to mitigate the impacts of HABs on human health and well-being.

\section{Better quantification and prevention of the impacts on human health: HAB-related disease surveillance}

Determining the true incidence of HAB-related diseases remains a very significant challenge. The lack of experience of professionals in the public health and medical communities with patients exposed to marine biotoxins (e.g. Pennotti et al., 2013) has led to incorrect diagnoses and failures to report illnesses. Inexperience, in turn, likely results in the underreporting of HAB-related disorders, even in areas where such diseases are endemic. Furthermore, in general, there is a lack of coordination between marine biotoxin monitoring and public health surveillance activities.

Under-reporting due to erroneous diagnosis is common and widespread, and is related, in part, to the lack of diagnostic tools. For instance, the symptoms of diarrhetic shellfish poisoning (DSP) are non-specific, and, except during exceptional outbreaks, neither seafood consumers nor their clinicians may recognize the incidence of DSP illness (e.g. Davidson et al., 2011; Taylor et al., 2013). Taylor \& Harrison (2002) query that '[n]o diarrhoeic shellfish poisoning has been diagnosed in humans in British Columbia, but, given its resemblance to diarrhoea caused by bacterial contamination (Vibrio haemolyticus, in particular), would DSP be detected without testing specifically for okadaic acid or dinophysistoxin?' Indeed, routine methods for the detection of either biotoxins or biomarkers in human tissues or fluids are virtually absent. [In 2011, nine years after Taylor had queried whether diarrhetic shellfish poisoning would be detected in the absence of testing for okadaic acid or dinophysistoxin, 62 illnesses of diarrhetic shellfish poisoning were reported in British Columbia. Changes were made to the shellfish monitoring programme following this outbreak to include more stringent testing for DSP toxins (Taylor et al., 2013).]

Diagnostic tools for saxitoxins in human urine have recently been developed (Johnson et al., 2009). A biomarker for lowlevel domoic acid exposure of zebra-fish and sea lions (Lefebvre et al., 2012), is a promising technology for identifying such biomarkers for humans. The verification of ciguatoxins in contaminated seafood has been particularly challenging. Recent advances suggest that an effective and reliable method will soon be available. Under the auspices of the International Atomic Energy Agency (IAEA), a radio-labelled receptor binding assay (RBA) was developed for ciguatoxin, and this 
assay has been tested successfully in the Caribbean and the Pacific at IAEA-UNESCO-IOC sponsored training workshops (Tester, personal communication). A more recent advance is a fluorescent RBA method that compares favourably with the radio-labelled RBA approach. The fluorescent method is analogous to a technique implemented for brevetoxins (e.g. McCall et al., 2012), in that no radioactivity is involved, making it less expensive to use, and avoiding hazardous waste disposal costs that can be significant, for example, in the Pacific islands.

HAB-associated illnesses are a public health issue, and, accordingly, public health surveillance could be coordinated with environmental monitoring. Until now, epidemiological studies typically have been conducted after clusters of disease outbreaks have occurred (although unfortunately usually without long-term follow-up to explore the chronic health effects from acute exposures). New multidiscipliary approaches could help to identify relevant bloom events, measure biotoxins in seawater (and in some cases air) and seafood, and identify symptoms in humans and other animals associated with exposures. In addition, communications with potentially affected communities could be conducted to promote the understanding that a particular symptom may be the result of exposure to a $\mathrm{HAB}$ biotoxin.

An example of such an approach can be found in the Gulf of Mexico, where the link between Karenia brevis blooms and human exposures and health effects, particularly to contaminated aerosols, was established. These efforts facilitated the successful understanding and mitigation of the human health risks associated with these events. This large and costly initiative included coordination among physicians, toxicologists, ecologists, stakeholders (including businesses, public health agencies, Poison Information Centres) and end-users (Fleming et al., 2005, 2011).

Another initiative with the same aim was the Harmful Algal Bloom-related Illness Surveillance System (HABISS) (http:// www.cdc.gov/hab/surveillance.htm) that the US Centers for Disease Control and Prevention (CDC) and other public health and environmental organizations established to create a coordinated human, animal and environmental health surveillance network. The simultaneous collection of environmental and health data over time was considered to have helped public health practitioners identify long-term trends in HAB-related diseases in humans and animals. The CDC also has created a module within the National Outbreak Reporting System (NORS) to capture HAB-related illnesses. Beta-testing of the system began in the summer of 2015 .

In Europe, similar initiatives, although at a smaller scale, have been established in the Mediterranean region to develop tools and strategies to manage the impacts of Ostreopsis blooms on human health before they can have a wider impact. Examples conducted at local scale include France (Tichadou et al., 2010; Lemée et al., 2012) and the Spanish Catalan coast (Vila et al., 2012), and the Accord RAMOGE (http://www.ramoge.org) at Mediterranean region level (mainly on the coasts of Italy, Monaco, France and Spain).

\section{HABs dynamics in the context of global climate change}

Climate plays a fundamental role in the physical dynamics of the water masses and energy pathways in the ocean, which in turn modulate the biogeochemical fluxes and thus nutrient supplies to microorganisms at the bases of food webs (Beaugrand et al., 2010). Climate variability modulates ecological events (phenology) and ecosystem characteristics at different spatio-temporal scales (Longhurst, 2007). As a result, the dynamics of HABs, as a natural phenomenon, are also influenced by climate variability.

The Earth's climate has changed continually over scales of millions of years, as evidenced by glacial and interglacial periods. Its climate also exhibits much shorter-term cyclical changes at multiannual to decadal and multi-decadal scales, such as those reflected in the El Niño Southern Oscillation (ENSO) and the North Atlantic Oscillation (NAO).

Photosynthetic organisms have evolved and adapted with changes occurring at these different temporal scales (e.g. Beardall \& Raven, 2004). In the last 200 years, however, since the industrial revolution, human activities have impacted the Earth dramatically, mainly as a consequence of the increasing release of carbon dioxide $\left(\mathrm{CO}_{2}\right)$, methane and nitrous oxides into the atmosphere. In particular, atmospheric $\mathrm{CO}_{2}$ concentration has increased from $280 \mathrm{ppm}$ to $>380 \mathrm{ppm}$ at present, with values of $750-1000 \mathrm{ppm}$ predicted by 2100 (IPCC, 2008), in comparison to fluctuations between 180 and $300 \mathrm{ppm}$ during the previous 800,000 years.

This rapid and uncontrolled rate of increase in so-called greenhouse gases has been responsible for an augmentation in about $1{ }^{\circ} \mathrm{C}$ of global temperature in the past $20-30$ years (data from the Hadley Centre for Climate Prediction and Research; shown in figure 1 of Hallegraeff, 2010), with a further rise of $2-4^{\circ} \mathrm{C}$ predicted over the next 100 years. Climate warming is already directly and indirectly impacting terrestrial and marine ecosystems. In the oceans, increased temperature in the upper layers can lead to changes in density which in turn affect the seasonal patterns of mixing, stratification and circulation, acidification, weakening or reinforcement of upwelling winds, and modification of the freshwater inflows to coastal regions (e.g. Bindoff et al., 2007). These changes may influence many ecological processes, including the occurrences of HABs. Given the impacts that HABs have on humans, there is now an urgent need to investigate the potential effects of climate warming on the occurrence of HABs. In addition, it will be important to develop tools for tracking and evaluating recent and future trends in $\mathrm{HAB}$ dynamics at both local and global scales.

The possible impacts of climate change on toxic marine HABs include: (1) range-changes in both warm- and cold-water species; (2) changes in abundance and toxicity; and (3) changes in the timing of the seasonal window of growth (e.g. Hays et al., 2005; Moore et al., 2008; Hallegraeff, 2010; Anderson et al., 2012; Fu et al., 2012). On the other hand, the effects of climate change on other components of the food webs (e.g. predators, competitors, parasites) could modulate the impact of climate change on the occurrence, magnitude and duration of HABs. Some HAB species may benefit such that their impact on human health and wellbeing becomes more severe, whereas others may diminish in areas that are currently impacted (Hallegraeff, 2010). Our ability to forecast the directions of change for toxic marine HABs is constrained by inadequate understanding of the interactions among multiple climate change variables and non-climate stressors in conjunction with inadequately 
designed experiments for investigating decadal- or centuryscale trends (Hallegraeff, 2010; Fu et al., 2012).

Few studies have investigated the effects of projected future climate change conditions on individual species or genera of toxin-producing marine microalgae. Of the few studies to date that have directly investigated future climate change effects on certain $\mathrm{HAB}$ species or genera, most have focused on the effects of warming. For example, the $2.5-3.5^{\circ} \mathrm{C}$ projected increase in sea surface temperature in the Caribbean over the coming century has been estimated to increase the incidence of CFP by 200-400\% (Gingold et al., 2014). In Puget Sound, warming has been projected to increase the seasonal window of growth for Alexandrium by $\sim 30$ days by 2040, allowing blooms to begin earlier in the year and to persist for longer periods (Moore et al., 2015). It is important to remember that these projections are primarily based on projected changes to water temperature. Other aspects of bloom ecology and oceanography, such as the location of nutrient availability, competition with other phytoplankton species, grazing, and infection by parasites, were not considered. Therefore, while these initial assessments of greenhouse gas-driven changes to $H A B$ risk provide insight into potentially important climate pathways that are relevant for bloom development, more work is needed to understand better the interactive effects of drivers other than temperature on $\mathrm{HAB}$ occurrence.

An emerging body of work is also focusing on the effects of ocean acidification on marine HABs. Some experiments performed on Pseudo-nitzschia fraudulenta found significantly high production of the domoic acid neurotoxin in response to a combination of low $\mathrm{pH}$ and some other factor that limits growth (Sun et al., 2011; Fu et al., 2012; Tatters et al., 2012a, b, 2013), provided that the limiting resource was not needed for toxin synthesis. Saxitoxin (paralytic shellfish toxin) production increased with elevated temperature and increased $\mathrm{CO}_{2}$ supply (Kremp et al., 2012), although the response was highly strain specific. Much more work is needed to understand the effect of increasing ocean acidification on HAB species, and thus the potential effect on human health and the ecosystems under this scenario.

In order to evaluate future trends of $\mathrm{HAB}$ events, there is a need to establish the present baseline. Several studies report that the occurrence and geographic distribution of toxic marine $\mathrm{HABs}$ has increased in certain areas during the past few decades (Hallegraeff, 1993, 2010; Van Dolah, 2000; Lewitus et al., 2012). Increased awareness, expanded and better monitoring and detection of toxic HABs, and the multiple effects and interactions of human activities (including, but not limited to, increased nutrient loading to coastal waters, aquaculture development and transport of seed stock, ballast water transport) and climate warming may have contributed to this putative increase (Smayda, 1990; Hallegraeff, 1993, 2010; Sellner et al., 2003; Gowen et al., 2012). Direct observations of microalgae in coastal marine waters on timescales sufficient to evaluate climate change effects and to discriminate the role of other natural or anthropogenic forcings (e.g. nutrient loads) are typically lacking. This makes it difficult to establish whether the observed trends are global or local (Davidson et al., 2012). While a few isolated time series do exist (e.g. Borkman \& Smayda, 2009; Kim et al., 2009), they have not yet been fully utilized to describe changes in the abundances of HAB species. In some cases, the available $\mathrm{HAB}$ data are from offshore, such as that generated by the Continuous Plankton Recorder (CPR) in the North Atlantic (Edwards et al., 2001, 2006; Hinder et al., 2012). Even though humans typically encounter HABs and their toxins at the coastal margins, these offshore time series provide valuable insights into the ecological responses of $\mathrm{HAB}$ species on timescales relevant to climate change. A small number of toxic $\mathrm{HAB}$ species leave a long-term record of their abundance in bottom sediments as microfossils (Dale et al., 2006) which could be used to explore time-series of bloom events. On the basis of similarities in the sediment cyst records in the Pacific and Atlantic regions of Canada, Mudie et al. (2002) concluded that climate change (including surface temperature and storminess) was a main factor stimulating blooms.

Reported illnesses are also an indicator of toxic HABs (Van Dolah, 2000); however, seafood is often consumed at long distances from where harvested. Unless robust information on the source of the seafood consumed is reported, it is difficult to identify potential relationships between food-borne HAB-related diseases and climate. Because most of the HAB-related diseases are associated with the consumption of contaminated shellfish, time series of HAB toxins in shellfish tissues provide valuable data for evaluating long-term trends and relationships to climate and in some cases date back to the 1950s (Trainer et al., 2003). The interactions of weather and climate are important for understanding patterns of disease, with climate determining the range of species and weather determining the timing and intensity of outbreaks (Dobson \& Carper, 1993; Epstein, 2001).

At present, it is clear that we lack sufficient scientific understanding of climate-driven changes to nearshore marine environments, as well as HAB responses to these potential changes, to provide accurate predictions of future $\mathrm{HAB}$ occurrences in space and time. One option to improve understanding of these changes would be to facilitate multidisciplinary research and coordination including stakeholders and policy makers with the objective to mitigate the impacts of HABs on human health and well-being. The concern about this need motivates discussions and meetings in different fora, such as the Symposium on 'HABs and Climate Change' held in Göteborg, Sweden, 19-22 May 2015 (https://pices.int/meetings/international_symposia/2015/2015-HAB/scope.aspx).

\section{Mitigation strategies for aquaculture}

In Japan, several strategies have been adopted to minimize economic losses to aquaculture (Imai et al., 2014). In southwest Hokkaido's Funka Bay, for example, the scallop culturing industry has adapted to frequent occurrences of dinoflagellate blooms that produce the dinophysis toxin and paralytic shellfish poisoning (PSP), which typically occur in May and continue into the summer. Modified approaches to harvesting were necessitated, in part, by high PSP contamination in the 1980 s that stopped shipments of all bivalves. Timing the scallop harvest every year from December to April avoids the impacts associated with the toxic bloom season. Scallops are harvested both for immediate fresh consumption, and they can be inventoried by boiling and freezing in order to provide a source of supply during the closed season.

In the Okhotsk Sea, recent occurrences of paralytic shellfish poisoning contamination of scallops have been predicted on the basis of movements of the Soya Warm Current. 
The strength of this current prevents the transport of Alexandrium tamarense, which typically resides in the offshore water masses of the Okhotsk Sea, to locations such as Monbetsu and Abashiri on the northern coast of Hokkaido. Adaptive harvesting in response to these forecasts is an effective way to avoid the impacts of toxic blooms on the bivalve aquaculture industry. This strategy is effective because of the fundamental understanding of local $\mathrm{HAB}$ dynamics.

Some strategies to mitigate the impacts of HABs on aquaculture may have been discounted prematurely and are worth revisiting. The use of clay to flocculate and remove toxic cells at some aquaculture sites in Asia (Sengco \& Anderson, 2004) is one example. This approach could be studied further to explore tradeoffs between the economic losses associated with fish kills from HABs, the environmental consequences of clay dispersal, the costs of implementing the mitigation technology, and toxin accumulation in the benthos.

\section{Communication with the public and improving literacy about oceans and HABs}

Throughout history, humans have learned how to cope with natural phenomena, including HABs. In some areas, such as in the Pacific Islands (Chinain et al., 201ob), local traditional knowledge about ciguatera is functionally correct, albeit scientifically incomplete.

The Spanish explorer Alvar Núñez Cabeza de Vaca $(1490-1558)$ recorded a place along the northern coast of Mexico in the Gulf of Mexico, probably not far from Apalache Bay, where indigenous peoples were unable to relate the passage of time to the movements of the sun and the moon, but instead marked the seasons by fishkills (Ferrando, 1984), which could have been caused then, as now, by blooms of Karenia brevis.

To people making a living around the Galician Rías, redtides ('purgas de mar') are familiar events, traditionally compared with menstruation, through which local waters are cleansed, usually in the autumn. It was general knowledge that it was unsafe to eat shellfish gathered when the ocean exhibited a reddish-brownish hue. When mass cultivation of mussels in the Galician Rías was undertaken by developers, who were ignorant of the blooms, the dispersal of toxic mussels became more frequent. One particularly extreme case occurred during the autumn of 1976 (Estrada et al., 1984).

Fukuyo et al. (2002) note that in Northern Japan, local folklore advises not to eat shellfish during runoff of snowmelt into the sea occurring in the early spring. In the UK and the USA, there is a similar folklore (O'Connor 2008; Whyte 2013): one should eat shellfish only during months that are spelled with the letter ' $r$ ', i.e. avoid shellfish consumption the summer months (May to August) when HABs are more likely to occur (although bacterial contamination of the food cannot be discounted). Perhaps, as Fukuyo et al. (2002) suggest, such folklore has arisen because:

this indicates that toxin contamination of shellfish has repeatedly occurred almost every year over a long time, leading to many tragedies among the local people. Community education resulted in self-regulating behaviour to avoid high-risk fish species and certain fishing locations.

Successful communication about HABs and their effects can be problematic for many different reasons. In part, this is due to the complexity of HAB phenomena, which are currently difficult to predict and to prevent or control. Most public health and medical personnel do not have in-depth knowledge about HABs and their potential effects on human health and wellbeing. Nowadays, many coastal communities are not fully informed of the public health risks of HABs, however, which can result in a phenomenon known as the 'halo effect', where human activities unrelated to the $\mathrm{HAB}$ hazards are scaled back or discontinued (Wessells et al., 1995; Whitehead et al., 2003; Parsons et al., 2006). A common form of the halo effect is a reduction in the consumption of all types of seafood, regardless of the actual risks of consuming phycotoxins. Other forms of the halo effect can influence commercial and recreational fishing behaviour and coastal tourism. Consequently, it would be beneficial to improve the scientific messages about HABs to the many and diverse end users and stakeholders.

Fortunately, there are now examples of interesting and potentially successful dissemination and early warning activities related to safeguarding human health from HAB-related toxic episodes. For example, the US National Oceanographic and Atmospheric Administration (NOAA) produces $\mathrm{HAB}$ Bulletins which provide forecasting of HABs for managers in the Gulf of Mexico (for Karenia brevis), in the Pacific North-west (for toxic Pseudo-nitzchia) and the Great Lakes (for cyanobacteria). The bulletins incorporate oceanographic modelling, satellite imagery and on-theground monitoring, as well as other information (e.g. realtime reports from lifeguards and managers). These materials were developed with stakeholder engagement and input, so that the outputs are actually useful for and used by the people (such as beach managers) who need timely information. Another example of appropriate communication was the implementation of a toll-free, 24/7-telephone number at the Miami Poison Information Centre staffed by poison specialists trained to discuss $\mathrm{HAB}$ exposure and illnesses in Florida. This resource was signposted on information panels and brochures placed in beaches, hotels and other tourist venues. Another useful aspect of this centralized information resource was that the poison control phone calls also could be incorporated into HAB human health surveillance activities to increase case reporting (Fleming et al., 2011).

Examples in Europe include HAB bulletins that are produced weekly in both Ireland and Scotland for the aquaculture industries in these countries (http://www.marine.ie/Home/ site-area/data-services/interactive-maps/weekly-hab-bulletin; http://www.somuchtosea.co.uk/news/ bulletin_for_shellfish_ farmers.aspx). In the Baltic, the Swedish Meteorological and Hydrological Institute Service offers reports and almost realtime information about the algae situation in the Baltic obtained from satellite data (http://www.smhi.se/en/weather/ sweden-weather/1.11631). In the NW Mediterranean, the RAMOGE Accord is working to communicate with the public and stakeholders, communicating through brochures and web pages, with dissemination activities about the occurrence of the Ostreopsis blooms and their impacts on human health and the environment, and searches to provide tools to manage them (http://www.ramoge.org/fr/ostreopsis_ovata. aspx). RAMOGE also fosters the coordination of international research around the understanding and management of these events in the affected countries. 


\section{International coordination: the GEOHAB and GlobalHAB programmes}

$\mathrm{HABs}$ are a global challenge which needs to be addressed at local levels by implementing a broad global vision. During the last few decades, much work has been accomplished to understand $\mathrm{HAB}$ dynamics with the ultimate aim of predicting their occurrences and mitigating their impacts. Studies and monitoring of toxic phytoplankton and biotoxins have been conducted at local, national and regional levels, each with their own particular resources. In addition, international and interdisciplinary cooperation has been invaluable in advancing the science of HABs. As an international exemplar, this cooperative research has been fostered from 2000 to 2014, by the GEOHAB programme, 'Global Ecology and Oceanography of Harmful Algal Blooms' (http://www.geohab.info), with the financial support of SCOR (Scientific Committee on Oceanic Research) and IOC/UNESCO (Intergovernmental Oceanographic Commission of UNESCO). As stated in its Science Plan (GEOHAB, 2001): ' $\mathrm{t}$ ] he scientific goal of GEOHAB was to improve the ability to predict HABs by determining the ecological and oceanographic mechanisms underlying their population dynamics, and integrating biological, chemical, and physical studies supported by enhanced observation and modelling systems.'

GEOHAB acted as an umbrella and catalyst for organizing scientific research on HABs. Moreover, GEOHAB provided a common and interconnecting aim for individual needs and efforts. The initiatives sponsored by GEOHAB, including open science meetings, specific workshops, and training activities, were publicized as reports, books and special issues in international journals (http://www.geohab.info).

At the termination of GEOHAB in 2014, the international scientific community agreed that a coordinated research approach to $\mathrm{HABs}$ was beneficial and still necessary (see GEOHAB, 2014). Starting in 2015, a new programme, GlobalHAB, will build on the GEOHAB Science Plan, incorporating the present challenges and opportunities that international research on HABs requires (Figure 3). Taking multidisciplinary and international perspectives, GlobalHAB will integrate key aspects of climate warming and global change on HABs within the context of the field of 'oceans and human health.'

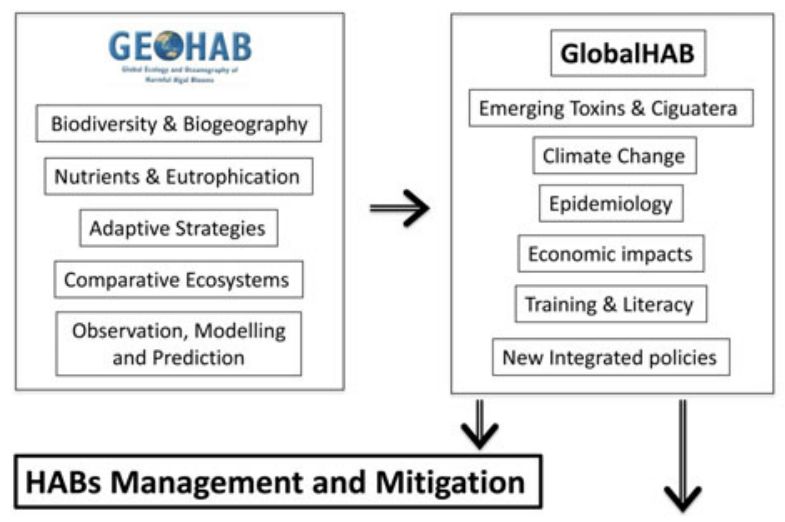

Better Oceans and Human Health

Fig. 3. Main elements of the international GEOHAB (2000-2014) and GlobalHAB (2015-2018) programmes, that aim to contribute to the advance of the research on HABs.

\section{CONCLUSIONS}

Microalgal blooms are a natural part of the seasonal cycle of the marine ecosystems around the world. They are key components of the structure and dynamics of the oceans and thus sustain the benefits (food supply, recreation, commerce, livelihood,) that humans obtain from this aquatic environment.

However, some microalgal blooms can be harmful to human health, impact valuable fisheries, and degrade other marine and coastal ecosystem services. The impacts of these $\mathrm{HABs}$ comprise acute and chronic health effects in humans, financial losses from contaminated seafood, mortalities of farmed fish, reduced coastal tourism and altered socio-cultural aspects. The losses due to HABs of passive values that humans place on protected species and extraordinary marine ecosystems are more difficult to quantify. There is evidence in some littoral areas that human pressures may have increased the occurrence of HABs. Further, global warming and changes in the climate regime also could affect HAB occurrences and toxicity, although forecasting the possible trends is still speculative.

At the beginning of the 21st century, with expanding human populations, particularly in coastal and developing countries, there is an urgent need to prevent and mitigate the impacts that HABs pose on human health and wellbeing.

Because HABs are natural phenomena, it is not possible to prevent their occurrence. However, the scientific research conducted over the last four decades, with the support of stakeholders, policymakers and the general public, has improved the understanding of $\mathrm{HAB}$ dynamics.

The achieved insights allow defining key priorities and designing strategies to mitigate the HABs impacts. In this paper, we have summarized part of the present knowledge and available tools to address this general objective. Around the world, at varying levels of government, certain promising efforts are being attempted to mitigate $\mathrm{HAB}$ impacts. These efforts include:

- Integrating both ecosystem and human health monitoring for $\mathrm{HAB}$ impacts. This involves maintaining or expanding existing $\mathrm{HAB}$ and biotoxin monitoring, and implementing new monitoring programmes where necessary. It also includes the monitoring of physico-chemical and meteorological variables to help ascertain the real effects of climate and other environmental changes on HAB occurrences and their impacts.

- Maintaining and reinforcing initiatives and local and international policies to reduce human pressures on the marine environment that may increase the occurrence of HABs and the severity of associated events.

- Developing an increased public "ocean literacy" and expanded engagement with coastal and ocean stakeholders.

We have also identified key research needs that, if addressed, could greatly enhance our understanding over HABs and their impacts on health. These questions include:

- Ascertaining real trends in ciguatera fish poisoning incidence, and provide informed projections of potential future trends.

- Ascertaining the risks of new emerging HABs and biotoxins (e.g., azaspiracid food-borne poisonings, BMAA and 
neuromuscular diseases, and respiratory irritation in new areas impacted by Ostreopsis blooms).

- Investigating the responses of HABs (especially regarding toxin production) to multifactorial physico-chemical climate drivers and the potential of marine microalgae to adapt genetically and phenotypically to the unprecedented rapidity of current climate and other environmental changes. This will require multidisciplinary collaboration and appropriately scaled experimental designs.

- Investigating possible interconnections between sociocultural aspects of human wellbeing and $\mathrm{HAB}$ events.

- Advancing in the estimation of the economic costs of HAB events.

Overall, we emphasize that collaborative research across natural and social scientific disciplines, as for example, the Florida Red Tide Research Group and GEOHAB, can lead to significant advances in our understanding of HABs, helping to develop approaches at local and global levels to lessen their impacts on public health and human wellbeing.

\section{FINANCIAL SUPPDRT}

The research was funded in part by the UK Medical Research Council (MRC) and UK Natural Environment Research Council (NERC) for the MEDMI Project; the National Institute for Health Research Health Protection Research Unit (NIHR HPRU) in Environmental Change and Health at the London School of Hygiene and Tropical Medicine in partnership with Public Health England (PHE), and in collaboration with the University of Exeter, University College London and the Met Office; and the European Regional Development Fund Programme and European Social Fund Convergence Programme for Cornwall and the Isles of Scilly (University of Exeter Medical School).

EB was supported by the CTM2014-53818-R project, from the Spanish Government (MINECO). KDA was in receipt of funding from the BBSRC-NERC research programme for multidisciplinary studies in sustainable aquaculture: health, disease and the environment. P. Hess was supported by Ifremer (RISALTOX) and the Regional Council of the Pays de la Loire (COSELMAR). Porter Hoagland was supported by the US National Science Foundation under NSF/CNH grant no. 1009106.

This work contributes to the implementation of the objectives of the SCOR and IOC/UNESCO funded programmes GEOHAB and GlobalHAB.

\section{REFERENCES}

Aasen J.A.B., Espenes A., Miles C.O., Samdal I.A., Hess P. and Aune T. (2011) Combined oral toxicity of azaspiracid-1 and yessotoxin in female NMRI mice. Toxicon 57, 909-917.

Adams J.A., Seaton D.D., Buchanan J.B. and Longbottom M.R. (1968) Biological observations associated with the toxic phytoplankton bloom off the East Coast. Nature 220, 24-25.

Aligizaki K., Katikou P., Milandri A. and Diogène J. (2011) Occurrence of palytoxin-group toxins in seafood and future strategies to complement the present state of the art. Toxicon 57, 390-399.
Aligizaki K., Katikou P., Nikolaidis G. and Panou A. (2008) First episode of shellfish contamination by palytoxin-like compounds from Ostreopsis species (Aegean Sea, Greece). Toxicon 51, 418-427.

Alonso E., Otero P., Vale C., Alfonso A., Antelo A., Giménez-Llort L., Chabaud L., Guillou C. and Botana L.M. (2013) Benefit of 13-desmethyl spirolide $\mathrm{C}$ treatment in triple transgenic mouse model of Alzheimer disease: B-Amyloid and neuronal marker improvement. Current Alzheimer Research 10, 279-289.

Alonso E., Vale C., Vieytes M.R., Laferla F.M., Gimenez-Llort L. and Botana L.M. (2011a) 13-Desmethyl spirolide-C is neuroprotective and reduces intracellular A beta and hyperphosphorylated tau in vitro. Neurochemistry International 59, 1056-1065.

Alonso E., Vale C., Vieytes M.R., Laferla F.M., Gimenez-Llort L. and Botana L.M. (2011b) The cholinergic antagonist gymnodimine improves a beta and tau neuropathology in an in vitro model of Alzheimer disease. Cellula Physiology and Biochemistry 27, 783-794.

Àlvarez J., Pedrol A., Parrón I., Goxencia J., de Torres M., Manzanera M., Planas C., Cosculluela G. and López A. (2005) Brote Epidémico de sintomatología irritativa en Sant Andreu de Llavaneres: ¿el origen está en el mar? In Proceedings of the XXIII Reunión de la Sociedad Española de Epidemiología, Las Palmas de Gran Canaria, Spain. Gaceta Sanitaria 19 Supplement 1, 3-139.

Amzil Z., Sibat M., Chomérat N., Grossel H., Marco-Miralles F., Lemee R., Nézan E. and Séchet V. (2012) Ovatoxin-a and palytoxin accumulation in seafood in relation to Ostreopsis cf. ovata blooms on the French Mediterranean coast. Marine Drugs 10, 477-496.

Amzil Z., Sibat M., Royer F. and Savar V. (2008) First report on azaspiracid and yessotoxin groups detection in French shellfish. Toxicon 52, $39-48$.

Anderson C.R., Siegel D.A., Kudela R.M. and Brzezinski M.A. (2009) Empirical models of toxigenic Pseudo-nitzschia blooms: potential use as a remote detection tool in the Santa Barbara Channel. Harmful Algae 8, 478-492.

Anderson D.M., Cembella A.D. and Hallegraeff G.M. (2012) Progress in understanding harmful algal blooms: paradigm shifts and new technologies for research, monitoring, and management. Annual Review of Marine Science 4, 143-176.

Anderson D.M., Glibert P.M. and Burkholder J.M. (2002) Harmful algal blooms and eutrophication: nutrient sources, composition, and consequences. Estuaries 25, 704-726.

Anderson D.M., Keafer B.A., Geyer W.R., Signell R.P. and Loder T.C. (2005a) Toxic Alexandrium blooms in the western Gulf of Maine: the plume advection hypothesis revisited. Limnology and Oceanography $50,328-345$.

Anderson D.M. and McCarthy S. (2012) Red tides and harmful algal blooms: impacts on desalination operations. Muscat Oman: Middle East Desalination Research Center (Report).

Anderson D.M., Stock C.A., Keafer B.A., Nelson A.B., McGillicuddy D.J., Keller M., Thompson B., Matrai P.A. and Martin J. (2005b) Alexandrium fundyense cyst dynamics in the Gulf of Maine. Deep-Sea Research II 52, 2522-2542.

Anderson D.M., Sullivan J.J. and Reguera B. (1989) Paralytic shellfish poisoning in northwest Spain: the toxicity of the dinoflagellate Gymnodinium catenatum. Toxicon 27, 665-674.

Arin L., Guillén J., Segura-Noguera M. and Estrada M. (2013) Open sea hydrographic forcing nutrient and phytoplankton dynamics in a Mediterranean coastal ecosystem. Estuarine Coastal and Shelf Science 133, 116-128.

Aune A., Espenes A., Aasen J.A.B., Quilliam M.A., Hess P. and Larsen S. (2012) Study of possible combined toxic effects of azaspiracid-1 and okadaic acid in mice via the oral route. Toxicon 60, 895-906. 
Ayres P. (1975) Mussel poisoning in Britain with special reference to paralytic shellfish poisoning. Review of cases reported 1814-1968. Environmental Health 83, 261-265.

Azanza R.V. (1999) Seafood poisoning from harmful algal blooms in coastal areas (abstract only). IOC-SOA International Workshop on Coastal Megacities: Challenges of Growing Urbanisation of the World's Coastal Areas Intergovernmental Oceanographic Commission Workshop (Hangzhou, People's Republic of China 2730 September 1999) UNESCO. Report, 166.

Azanza R.V. and Taylor F.J.R. (2001) Are Pyrodinium blooms in the Southeast Asian region recurring and spreading? A view at the end of the millennium. Ambio 30, 356-364.

Bachvaroff T.R., Adolf J.E., Squier A.H., Harvey H.R. and Place A.R. (2008) Characterization and quantification of karlotoxins by liquid chromatography-mass spectrometry. Harmful Algae 7, 473-484.

Backer L.C., Fleming L.E., Rowan A., Cheng Y.-S., Benson J., Pierce R.H., Zaias J., Bean J., Bossart G.D., Johnson D., Quimbo R. and Baden D.G. (2003) Recreational exposure to aerosolized brevetoxins during Florida red tide events. Harmful Algae 2, 19-28.

Backer L.C., Kirkpatrick B., Fleming L.E., Cheng Y.S., Pierce R., Bean J.A., Clark R., Johnson D., Wanner A., Tamer R. and Baden D. (2005) Occupational exposure to aerosolized brevetoxins during Florida red tide events: impacts on a healthy worker population. Environmental Health Perspectives 113, 644-649.

Backer L.C. and Moore S.K. (2011) Harmful algal blooms: future threats in a warmer world. In El Nemr A. (ed.) Environmental pollution and its relation to climate change. New York, NY: Nova Science Publishers, pp. 495-561.

Baden D.G. and Trainer V.L. (1993) Mode of action of toxins of seafood poisoning. In Falconer I. (ed.) Algal toxins in seafood and drinking water. New York, NY: Academic Press, pp. 49-74.

Bagnis R., Kuberski T. and Laugeir S. (1979) Clinical observations on 3009 cases of ciguatera (fish poisoning) in the South Pacific. American Journal of Tropical Medicicne and Hygiene 28, 1067-1073.

Baron A.W., Steeg R., Morris C.M., Blain P.G. and Judge S.J. (2011) Motor activity is a sensitive behavioural biomarker of low level exposure to the shellfish toxin, domoic acid, in male and female rats. Toxicology 290, 122.

Barroso García P., Rueda de la Puerta P., Parron Carreno T., Marín Martínez P. and Enriquez J.G. (2008) Brote con sintomas respiratorios en la provincia de Almería por una posible exposicion a microalgas toxicas. Gaceta Sanitaria 22, 578-584.

Bates S.S., Bird C.J., de Freitas A.S.W., Foxall R., Gilgan M., Hanic L.A., Johnson G.R., McCulloch A.W., Odense P., Pocklingtonm R., Quilliam M.A., Sim P.G., Smith J.C., Subba Rao D.V., Todd E.C.D., Walter J.A. and Wright J.L.C. (1989) Pennate diatom Nitzschia pungens as the primary source of domoic acid, a toxin in shellfish from eastern Prince Edward Island, Canada. Canadian Journal of Fisheries and Aquatic Sciences 46, 1203-1215.

Bauer M., Hoagland P., Leschine T.M., Blount B.G., Pomeroy C.M. Lampl L.L., Scherer C.W., Ayres D.L., Tester P.A., Sengco M.R., Sellner K.G. and Schumacker J. (2009) The importance of human dimensions research in managing harmful algal blooms. Frontiers in Ecology and the Environment 8, 75-83.

Bean J.A., Fleming L.E., Kirkpatrick B., Backer L.C., Nierenberg K. Reich A., Cheng Y.S., Wanner A., Benson J., Naar J., Pierce R., Abraham W.M., Kirkpatrick G., Hollenbeck J., Zaias J., Mendes E. and Baden D.G. (2011) Florida red tide toxins (brevetoxins) and longitudinal respiratory effects in asthmatics. Harmful Algae 10, 744-748.

Beardall J. and Raven J.A. (2004) The potential effects of global climate change on microalgal photosynthesis, growth and ecology. Phycologia $43,26-41$.
Beaugrand G., Edwards M. and Legendre L. (2010) Marine biodiversity, ecosystem functioning, and carbon cycles. Proceedings of the National Academy of Sciences USA 107, 10120-10124.

Berdalet E., Vila M. and Abós-Herràndiz R. (2015) Expansion of the benthic dinoflagellate Ostreopsis with climate change: health risks assessment and policy strategies for management. Harmful Algal Blooms and Climate Change Scientific Symposium. Göteborg, Sweden, 19-22 May 2015. https://pices.int/meetings/international_ symposia/2015/2015-HAB/scope.aspx

Bernard S., Kudela R.M. and Velo-Suárez L. (2014) Developing global capabilities for the observation and prediction of harmful algal blooms. In Djavidnia S., Cheung V., Ott M. and Seeyave S. (eds) Oceans and society: blue planet. Cambridge Scholars Publishing, Chapter 6.

Bindoff N.L., Willebrand J., Artale V., Cazenave A., Gregory J., Gulev S., Hanawa K., Le Quéré C., Levitus S., Nojiri Y., Shum C.K., Talley L.D. and Unnikrishnan A. (2007) Observations: oceanic climate change and sea level. In Solomon S., Qin D., Manning M., Chen Z., Marquis M., Averyt K.B., Tignor M., Miller H.L. (eds) Climate change 2007: the physical science basis contribution of working group I to the fourth assessment report of the intergovernmental panel on climate change. Cambridge: Cambridge University Press, pp. 385-432.

Biré R., Trotereau S., Lemée R., Delpont C., Chabot B., Aumond Y. and Krys S. (2013) Occurrence of palytoxins in marine organisms from different trophic levels of the French Mediterranean coast harvested in 2009. Harmful Algae 28, 10-22.

Black E.A., Whyte J.N.C., Bagshaw J.W. and Ginther N.G. (1991) The effects of Heterosigma akashiwo on juvenile Oncorhynchus tshawytscha and its implications for fish culture. Journal of Applied Ichthyology 7, 168-175.

Blanco J., Correa J., Muñiz S., Mariño C., Martín H. and Arévalo F. (2013) Evaluación del impacto de los métodos y niveles utilizados para el control de toxinas en el mejillón. Revista Galega dos Recursos Mariños 3, 1-55.

Blanco J., Moroño A. and Fernández M.L. (2005) Toxic episodes in shellfish produced by lipophilic phycotoxins: an overview. Galician Journal of Marine Resources 1, 70.

Blossom H.A., Andersen N.G., Rasmusse S.A. and Hansen P.J. (2014) Stability of the intra- and extracellular toxins of Prymnesium parvum using a microalgal bioassay. Harmful Algae 32, 11-21.

Boni L., Mancini L., Milandri A., Poletti R., Pompei M. and Viviani R. (1992) First cases of diarrhetic shellfish poisoning in the Northern Adriatic Sea. In Vollenweider R.A., Marchetti R. and Viviani R. (eds) Marine coastal eutrophication. Amsterdam: Elsevier, pp. 419-426.

Borkman D.G. and Smayda T. (2009) Multidecadal (1959-1997) changes in Skeletonema abundance and seasonal bloom patterns in Narragansett Bay, Rhode Island, USA. Journal of Sea Research 61, 84-94.

Bossart G.D., Baden D.G., Ewing R.Y. and Wright S.D. (2002) Manatees and brevetoxicosis. In Pfeiffer C. (ed.) Molecular and cell biology of marine mammals. Melbourne, FL: Krieger Publishing Co., pp. 205-212.

Bradley W.G., Borenstein A.R., Nelson L.M., Codd G.A., Rosen B.H., Stommel E.W. and Cox P.A. (2013) Is exposure to cyanobacteria an environmental risk factor for amyotrophic lateral sclerosis and other neurodegenerative diseases? Amyotrophic Lateral Sclerosis and Frontotemporal Degeneration 14, 325-333.

Brand L.E., Pablo J., Compton A., Hammerschlag N. and Mash D.C. (2010) Cyanobacterial blooms and the occurrence of the neurotoxin, beta-N-methylamino-L-alanine (BMAA), in South Florida aquatic food webs. Harmful Algae 9, 620-635.

Bravo I., Vila M., Casabianca S., Rodríguez F., Rial P., Riobó P. and Penna A. (2012) Life cycle stages of the benthic palytoxin-producing 
dinoflagellate Ostreopsis cf. ovata (Dinophyceae). Harmful Algae 18, 24-34.

Brescianini C., Grillo C., Melchiorre N., Bertolotto R., Ferrari A., Vivaldi B., Icardi G., Gramaccioni L., Funari E. and Scardala S. (2006) Ostreopsis ovata algal blooms affecting human health in Genova, Italy, 2005 and 2006. Euro Surveillance 11, E060907.

Bricelj V.M. and Lonsdale D.J. (1997) Aureococcus anophagefferens: causes and ecological consequences of brown tides in U.S mid-Atlantic coastal waters. Limnology and Oceanography 42, $1023-$ 1038.

Brissard C., Herrenknecht C., Séchet V., Hervé F., Pisapia F., Harcouet J., Lémée R., Chomérat N., Hess P. and Amzil Z. (2014) Complex toxin profile of French Mediterranean Ostreopsis cf. ovata strains, seafood accumulation and ovatoxins prepurification. Marine Drugs $12,2851-2876$.

Brissard C., Hervé F., Sibat M., Séchet V., Hess P., Amzil Z. and Herrenknecht C. (2015) Characterization of ovatoxin-h, a new ovatoxin analog, and evaluation of chromatographic columns for ovatoxin analysis and purification. Journal of Chromatography A 1388, 87-101.

Brown C.W., Green D., Hickey B.M., Jacobs J.M., Lanerolle L.W.J., Moore S., Schwab D.J., Trainer V.L., Trtanj J., Turner E., Wood R.J. and Wynne T.T. (2012) Towards operational forecasts of algal blooms and pathogens. In Morain S.A. and Budge A.M. (eds) Environmental tracking for public health surveillance, 1 st edn. Leiden: CRC Press, pp. 345-368.

Bruno D.W., Dear D. and Seaton D.D. (1989) Mortality associated with phytoplankton blooms among farmed Atlantic salmon, Salmo salar L. in Scotland. Aquaculture 78, 217-222.

Bruslé J. (1997) Ciguatera fish poisoning - a review. Sanitary and economic aspects. Paris: Les éditions INSERM, 147 pp.

Campbell K., McNamee S.E., Huet A.C., Delahaut P., Vilarino N., Botana L.M., Poli M. and Elliott C.T. (2014) Evolving to the optoelectronic mouse for phycotoxin analysis in shellfish. Analytical and Bioanalytical Chemistry 406, 6867-6881.

Campbell L., Henrichs D.W., Olson R.J. and Sosik H.M. (2013) Continuous automated imaging-in-flow cytometry for detection and early warning of Karenia brevis blooms in the Gulf of Mexico. Environmental Science and Pollution Research 20, 6896-6902.

Campbell L., Olson R.J., Sosik H.M., Abraham A., Henrichs D.W., Hyatt C.J. and Buskey E.J. (2010) First harmful Dinophysis (Dinophyceae, Dinophysiales) bloom in the U.S. is revealed by automated imaging flow cytometry. Journal of Phycology 46, 66-75.

Caron D.A., Gurnee M.-E., Seubert E., Howard M.D.A., Darjany L., Schnetzer A., Cetinic I., Filteau G., Lauri P., Jones B. and Trussell S. (2010) Harmful algae and their potential impacts on desalination operations off southern California. Water Research 44, 385-416.

Casabianca S., Casabianca A., Riobó P., Franco J.M., Vila M. and Penna A. (2013) Quantification of the toxic dinoflagellate Ostreopsis spp. by qPCR assay in marine aerosol. Environmental Science and Technology $47,3788-3795$

Chateau-Degat M.L., Chinain M., Cerf N., Gingras S., Hubert B. and Dewailly E. (2005) Sea water temperature, Gambierdiscus spp. variability and incidence of ciguatera poisoning in French Polynesia. Harmful Algae 4, 1053-1062.

Chateau-Degat M.L., Chinain M., Darius H.T., Dewailly E. and Mallet H.P. (2009) Epidemiological surveillance of ciguatera in French Polynesia. Bulletin Epidémiologique Hebdomadaire Thématique $48-$ 50, 522-525.

Chinain M., Darius H.T., Ung A., Cruchet P., Wang Z., Ponton D., Laurent D. and Pauillac S. (2010a) Growth and toxin production in the ciguatera-causing dinoflagellate Gambierdiscus polynesiensis (Dinophyceae) in culture. Toxicon 56, 739-750.

Chinain M., Darius H.T., Ung A., Fouc M.T., Revel T., Cruchet P., Pauillac S. and Laurent D. (2010b) Ciguatera risk management in French Polynesia: the case study of Raivavae Island (Australes Archipelago). Toxicon 56, 674-690.

Ciminiello P., Dell'Aversano C., Dello Iacovo E., Fattorusso E., Forino M., Grauso L., Tartaglione L., Guerrini F. and Pistocchi R. (2010) Complex palytoxin-like profile of Ostreopsis ovata. Identification of four new ovatoxins by high-resolution liquid chromatography/mass spectrometry. Rapid Communications in Mass Spectrometry 24, $2735-2744$.

Ciminiello P., Dell'Aversano C., Dello Iacovo E., Fattorusso E., Forino M. and Tartaglione L. (2011) LC-MS of palytoxin and its analogues: state of the art and future perspectives. Toxicon 57, 376-389.

Ciminiello P., Dell'Aversano C., Dello Iacovo E., Fattorusso E., Forino M. and Tartaglione L. (2014) First finding of Ostreopsis cf. ovata toxins in marine aerosols. Environmental Science and Technology 48, 3532-3540.

Ciminiello P., Dell'Aversano C., Dello Iacovo E., Fattorusso E., Forino M., Tartaglione L., Yasumoto T., Battocchi C., Giacobbe M., Amorim A. and Penna A. (2013) Investigation of toxin profile of Mediterranean and Atlantic strains of Ostreopsis cf. siamensis (Dinophyceae) by liquid chromatography-high resolution mass spectrometry. Harmful Algae 23, 19-27.

Ciminiello P., Dell'Aversano C. and Forino M. (2015) Chemistry of palytoxin and its analogues. In Botana L. and Alfonso A. (eds) Phycotoxins: chemistry and biochemistry. Hoboken, NY: WileyBlackwell, pp. 85-111.

Coulson J.C., Potts G.R., Deans I.R. and Fraser S.M. (1968) Mortality of shags and other sea birds caused by paralytic shellfish poisoning. Nature 220, 23-24.

Cox P.A., Banack S.A., Murch S.J., Rasmussen U., Tien G., Bidigare R.R., Metcalf J.S., Morrison L.F., Codd G.A. and Bergman B. (2005) Diverse taxa of cyanobacteria produce $\beta-\mathrm{N}$-methylaminol-alanine, a neurotoxic amino acid. Proceedings of the National Academy of Sciences USA 102, 5074-5078.

Dahl E. and Tangen K. (1990) Gyrodinium aureolum bloom along the Norwegian coast in 1988. In Granéli E., Sundstrøm B., Edler L. and Anderson D.M. (eds) Toxic marine phytoplankton. Amsterdam: Elsevier, pp. $123-127$.

Dahl E. and Tangen K. (1993) 25 years experience with Gyrodinium aur eolum in Norwegian waters. In Smayda T.J. and Shimizu Y. (eds) Toxic phytoplankton blooms in the sea. New York, NY: Elsevier, pp. 15-21.

Daigo K. (1959) Constituents of Chondria armata. III. Constitution of domoic acid. Journal of the Pharmaceutical Society of Japan. Yakugaku Zasshi 79, 360-364. [In Japanese, with English abstract]

Dale B., Edwards M. and Reid P.C. (2006) Climate change and harmful algae blooms. In Granéli E. and Turner J.T. (eds) Ecology of harmful algae. Ecological studies No. 189. Heidelberg: Springer-Verlag, pp. $367-378$.

Davidson K. (2014) The challenges of incorporating realistic simulations of marine protists in biogeochemically based mathematical models. Acta Protozoologica 53, 129-138.

Davidson K. and Bresnan E. (2009) Shellfish toxicity in UK waters: a threat to human health? Environmental Health 8 Supplement 1, S12.

Davidson K., Gowen R.J., Harrison P.J., Fleming L., Hoagland P. and Moschonas G. (2014) Anthropogenic nutrients and harmful algae in coastal waters. Journal of Environmental Management 146, 206-216.

Davidson K., Gowen R.J., Tett P., Bresnan E., Harrison P.J., McKinney A., Milligan S., Mills D.K., Silke J. and Crooks A.-M. (2012) Harmful algal blooms: how strong is the evidence that nutrient ratios and forms 
influence their occurrence? Estuarine Coastal and Shelf Science 115, $399-413$.

Davidson K., Miller P.I., Wilding T., Shutler J., Bresnan E., Kennington K. and Swan S. (2009) A large and prolonged bloom of Karenia mikimotoi in Scottish waters in 2006. Harmful Algae 8, 349-361.

Davidson K., Tett P. and Gowen R. (2011) Harmful algal blooms. In Hester R.E. and Harrison R.M. (eds) Marine pollution and human health. Issues in environmental science and technology, no. 33. Cambridge: Royal Society of Chemistry, pp. 95-127.

Deeds J.R., Landsberg J.H., Etheridge S.M., Pitcher G.C. and Longan S.W. (2008) Non-traditional vectors for paralytic shellfish poisoning. Marine Drugs 6, 308-348.

Deeds J.R. and Schwartz M.D. (2010) Human risk associated with palytoxin exposure. Toxicon 56, 150-162.

DeGrasse S.L. and Martinez-Diaz K. (2012) Biotoxin control programmes in North, Central and South American countries. In Cabado A.G. and Vieites J.M. (eds) New trends in marine and freshwater toxins: food safety concerns. New York, NY: Nova Science Publishers.

Dewailly E., Chateau-Degat M.L. and Suhas E. (2008) Fish consumption and health in French Polynesia. Asian Pacific Journal of Clinical Nutrition 17, 86-93.

Dixon M.B., Falconet C., Ho L., Chow C.W.K., O’Neill B.K. and Newcombe G. (2011a) Removal of cyanobacterial metabolites by nanofiltration from two treated waters. Journal of Hazardous Materials 188, 288-295.

Dixon M.B., Richard Y., Ho L., Chow C.W.K., O'Neill B.K. and Newcombe G. (2011b) A coagulation-powdered activated carbon-ultrafiltration-multiple barrier approach for removing toxins from two Australian cyanobacterial blooms. Journal of Hazardous Materials 186, 1553-1559.

Dobson A. and Carper R. (1993) Biodiversity. Lancet 342, 1096-1099.

Durando P., Ansaldi F., Oreste P., Moscatelli P., Marensi L., Grillo C., Gasparini R., Icardi G. and the Collaborative Group for the Ligurian Syndromic Algal Surveillance (2007) Ostreopsis ovata and human health: epidemiological and clinical features of respiratory syndrome outbreaks from a two-year syndromic surveillance, 2005-2006, in north-west Italy. Eurosurveillance 12, 1-4.

Edwards M., Johns D.G., Leterme S.C., Svendsen E. and Richardson A.J. (2006) Regional climate change and harmful algal blooms in the northeast Atlantic. Limnology and Oceanography 51, 820-829.

Edwards M., Reid P.C. and Planque B. (2001) Long-term and regional variability of phytoplankton biomass in the Northeast Atlantic (1960-1995). ICES Journal of Marine Science 58, 39-49.

EFSA Panel on Contaminants in the Food Chain (CONTAM) (2009) Scientific opinion on marine biotoxins in shellfish - Palytoxin group. EFSA Journal 7. doi: 10.2903/j.efsa.2009.1393.

Elbrächter M. and Qi Y.Z. (1998) Aspects of Noctiluca (Dinophyceaea) population dynamics. In Anderson D.M., Cembella A.D. and Hallegraeff G.M. (eds) Physiological ecology of harmful algal blooms. Heidelberg: Springer- Verlag, pp. 133-153.

Endo M., Sakai T. and Kuroki A. (1985) Histological and histochemical changes in the gills of the yellowtail Seriola quinqueradiata exposed to the Raphidophycean flagellate Chattonella marina. Marine Biology 87, 193-197.

Epelboin L., Pérignon A., Hossen V., Vincent R., Krys S. and Caumes E. (2014) Two clusters of ciguatera fish poisoning in Paris, France, related to tropical fish imported from the French Caribbean by travelers. Journal of Travel Medicine 21, 397-402.
Epstein P. and Rapport D.J. (1996) Changing coastal marine environments and human health. Ecosystem Health 2, 166-176.

Epstein P.R. (2001) Climate change and emerging infectious diseases. Microbes and Infection 3, 747-754.

Estrada M., Sánchez F.J. and Fraga S. (1984) Gymnodinium catenatum (Graham) en las rías gallegas (NO de España). Investigación Pesquera 48, 31-40.

European Commission (2011) Commission Regulation (EU) No 15/2011 of 10 January 2011 amending Regulation (EC) No 2074/2005 as regards recognised testing methods for detecting marine biotoxins in live bivalve molluscs. Official Journal L6, 3-6. Available online: http://eur-lex. europa.eu/legal-content/EN/TXT/?uri=celex:32011Roo15 (accessed 4 November 2015).

Falconer I. (1998) Algal toxins and human health. In Hrub J. (ed.) The handbook of environmental chemistry. Berlin: Springer-Verlag, pp. $53-82$.

FAO (2006) State of world aquaculture, 2006. FAO Fisheries Technical Report Paper No. 500. Rome: Inland Water and Aquaculture Service. Fishery Resources Division, FAO Fisheries Department.

Fehling J., Davidson K., Bolch C.J. and Bates S.S. (2004) Growth and domoic acid production by Pseudo-nitzschia seriata (Bacillariophyceae) under phosphate and silicate limitation. Journal of Phycology 40, 674-683.

Ferrando R. (1984) Álvar Núñez Cabeza de Vaca, Naufragios y Comentarios, Volume 16. Madrid: Historia, 318 pp.

Fistarol G.O., Legrand C. and Granéli E. (2003) Allelopathic effect of Prymnesium parvum on a natural plankton community. Marine Ecology Progress Series 255, 115-125.

Fleming L.E., Backer L. and Rowan A. (2002) The epidemiology of human illnesses associated with harmful algal blooms. In Baden D. and Adams D. (eds) Neurotoxicology handbook, Vol. 1. Totowa, NJ: Humana Press, pp. 363-381.

Fleming L.E., Kirkpatrick B., Backer L.C., Bean J.A., Wanner A., Dalpra D., Tamer R., Zaias J., Cheng Y.S., Pierces R., Naar J., Abraham W., Clark R., Zhou Y., Henry M.S., Johnson D., Van de Bogart G., Bossart G.D., Harrington M. and Baden D.G. (2005) Initial evaluation of the effects of aerosolized Florida red tide toxins (brevetoxins) in persons with asthma. Environmental Health Perspectives 113-5, 650-657.

Fleming L.E., Kirkpatrick B., Backer L.C., Bean J.A., Wanner A., Reich A., Zaias J., Cheng Y.S., Pierce R., Naar J., Abraham W.M. and Baden D.G. (2006) Aerosolized red tide toxins (Brevetoxins) and asthma. Chest 131, 187-194.

Fleming L.E., Kirkpatrick B., Backer L.C., Walsh C.J., Nierenberg K., Clark J., Reich A., Hollenbeck J., Benson J., Cheng Y.S., Naar J., Pierce R., Bourdelais A.J., Abraham W.M., Kirkpatrick G., Zaias J., Wanner A., Mendes E., Shalat S., Hoagland P., Stephan W., Bean J., Watkins S., Clarke T., Byrne M. and Baden D.G. (2011) Review of Florida red tide and human health effects. Harmful Algae $20,224-233$.

Fleming L.E., McDonough N., Austen M., Mee L., Moore M., Hess P., Depledge M.H., White M., Philippart K., Bradbrook P. and Smalley A. (2014) Oceans and human health: a rising tide of challenges and opportunities for Europe. Marine Environment Research 99, 16-19.

Flewelling L.J., Naar J.P., Abbott J.P., Baden D.G., Barros N.B., Bossart G.D., Bottein M-Y.D., Hammond D.G., Haubold E.M., Heil C.A., Henry M.S., Jacocks H.M., Leighfield T.A., Pierce R.H., Pitchford T.D., Rommel S.A., Scott P.S., Steidinger K.A., Truby E.W., Van Dolah F.M. and Landsberg J.H. (2005) Brevetoxicosis: Red tides and marine mammal mortalities. Nature (London) 435, 755-756. 
Fonda-Umani S., Beran A., Parlato S., Virgilio D., Zollet T., De Olazabal A., Lazzarini B. and Cabrini M. (2004) Noctiluca scintillans Macartney in the Northern Adriatic Sea: long-term dynamics, relationships with temperature and eutrophication, and role in the food web. Journal of Plankton Research 26, 545-561.

Fraga S. and Sánchez F.J. (1985) Toxic and potentially toxic dinoflagellates found in Galician Rías (NW Spain). In Anderson D.M., White A.W. and Baden D.G. (eds) Toxic dinoflagellates. Proceedings of the Third International Conference on Toxic Dinoflagellates, New Brunswick, Canada 8-12 June 1985. New York: Elsevier, pp. 51-54.

Freudenthal A.R. (1990) Public health aspects of ciguatera poisoning contracted on tropical vacations by North American tourists. In Graneli E., Sundstrom B., Edler L. and Anderson D.M. (eds) Toxic marine phytoplankton. New York, NY: Elsevier, pp. 463-468.

Friedman M.A., Fleming L.E., Fernandez M., Bienfang P., Schrank K., Dickey R., Bottein M.Y., Backer L., Ayyar R., Weisman R., Watkins S., Granade R. and Reich A. (2008) Ciguatera fish poisoning: treatment, prevention and management. Marine Drugs 6, 456-479.

Fritz S., Scholes R.J., Obersteiner M., Bouma J. and Reyers B. (2008) A conceptual framework for assessing the benefits of a global earth observation system of systems. IEEE Systems Journal 2, 338-348.

Frolov S., Kudela R.M. and Bellingham J.G. (2013) Monitoring of harmful algal blooms in the era of diminishing resources: a case study of the US west coast. Harmful Algae 21-22, 1-12.

Fu F.-X., Tatters A.O. and Hutchins D.A. (2012) Global change and the future of algal blooms in the ocean. Marine Ecology Progress Series 470, 207-233.

Fukuyo Y., Imai I., Kodama M. and Tamai K. (2002) Red tides and harmful algal blooms in Japan. In Taylor F.J. and Trainer V.L. (eds) Harmful algal blooms in the PICES region of the North Pacific. PICES Scientific Report No. 23. Sidney, BC: North Pacific Marine Science Organization (PICES), pp. 7-20.

Fux E., Biré R. and Hess P. (2009) Comparative accumulation and composition of lipophilic marine biotoxins in passive samplers and in mussels (M. edulis) on the West Coast of Ireland. Harmful Algae 8, 523-537.

Gaines G. and Taylor F.J.R. (1985) An exploratory analysis of PSP patterns in British Columbia. In Anderson D.M., White A.W. and Baden D.G. (eds) Toxic dinoflagellates. Proceedings of the Third International Conference on Toxic Dinoflagellates, New Brunswick, Canada 8-12 June 1985. New York, NY: Elsevier Science, pp. 439-444.

Gallitelli M., Ungaro N., Addante L.M., Silver N.G. and Sabbà C. (2005) Respiratory illness as a reaction to tropical algal blooms occurring in a temperate climate. Journal of the American Medical Association 293 $2599-2600$

Gentien P. (1998) Bloom dynamics and ecophysiology of the Gymnodinium mikimotoi species complex. In Anderson D.A., Cembella A.D. and Hallegraeff G.M. (eds) Physiological ecology of harmful algae blooms. Berlin: Springer, pp. 155-173.

GEOHAB (2001) Glibert P. and Pitcher G. (eds) Global ecology and oceanography of harmful algal blooms, science plan. Baltimore and Paris: SCOR and IOC, $87 \mathrm{pp}$.

GEOHAB (2005) Pitcher G., Moita T., Trainer V., Kudela R., Figueiras F.G. and Probyn T. (eds) Global ecology and oceanography of harmful algal blooms, GEOHAB Core Research Project: HABs in upwelling systems. Paris and Baltimore: IOC and SCOR, $82 \mathrm{pp}$.

GEOHAB (2006) Glibert P. (ed.) Global ecology and oceanography of harmful algal blooms, harmful algal blooms in eutrophic systems. Paris and Baltimore: IOC and SCOR, $74 \mathrm{pp}$.

GEOHAB (2008) Gentien P., Reguera B., Yamazaki H., Fernand L., Berdalet E. and Raine R. (eds) Global ecology and oceanography of harmful algal blooms, GEOHAB Core Research Project: HABs in Stratified Systems. Paris and Newark, DE: IOC and SCOR, 59 pp.

GEOHAB (2010) Furuya K., Glibert P.M., Zhou M. and Raine R. (eds) Global ecology and oceanography of harmful algal blooms, harmful algal blooms in Asia. Paris and Newark, DE: IOC and SCOR, 68 pp.

GEOHAB (2011) McGillicuddy D.J. Jr., Glibert P.M., Berdalet E., Edwards C., Francks P. and Ross O. (eds) GEOHAB modelling: a workshop report. Paris and Newark, DE: IOC and SCOR, 85 pp.

GEOHAB (2012) Berdalet E., Tester P.A. and Zingone A. (eds) Global Ecology and Oceanography of Harmful Algal Blooms, GEOHAB Core Research Project: HABs in Benthic Systems. Paris and Newark: SCOR and IOC of UNESCO, $64 \mathrm{pp}$.

GEOHAB (2014) Berdalet E., Bernard S., Burford M.A., Enevoldsen H., Kudela R., Magnien R., Roy S., Tester P., Urban E. and Usup G. (eds) Global ecology and oceanography of harmful algal blooms: synthesis open science meeting. Paris and Newark, DE: IOC and SCOR, 78 pp.

GESAMP (2001) Global Environment Outlook 3, EARTH SCAN, Past, present and future perspectives. Protecting the oceans from land-based activities. Land-based sources and activities affecting the quality and uses of the marine, coastal and associated freshwater environment. GESAMP Reports and Studies No. 71. Nairobi: United Nations Environment Programme.

Gingold D.B., Strickland M.J. and Hess J.J. (2014) Ciguatera fish poisoning and climate change: analysis of the National Poison Center data in the United States, 2001-2011. Environmental Health Perspectives 122, $580-586$.

Gobler C.J., Berry D.L., Anderson O.R., Burson A., Koch F., Rodgers B.S., Moore L.K., Goleski J.A., Allam B., Bowser P., Tang Y.Z. and Nuzzi R. (2008) Characterization, dynamics, and ecological impacts of harmful Cochlodinium polykrikoides blooms on eastern Long Island, NY, USA. Harmful Algae 7, 293-307.

Golubic S., Abed R.M.M., Palińska K., Pauillac S., Chinain M. and Laurent D. (2010) Marine toxic cyanobacteria: diversity, environmental responses and hazards. Toxicon 56, 836-841.

Gowen R.J., Tett P., Bresnan E., Davidson K., McKinney A., Harrison P.J., Milligan S., Mills D.K., Silke J. and Crooks A.-M. (2012) Anthropogenic nutrient enrichment and blooms of harmful microalgae. Oceanography and Marine Biology: An Annual Review 50, $65-126$.

Granéli E. and Hansen P.J. (2006) Allelopathy in harmful algae: a mechanism to compete for resources? In Granéli E. and Turner J.T. (eds) Ecology of harmful algae. Berlin: Springer Verlag, pp. 189-201.

Greenfield D., Marin III R., Doucette G.J., Mikulski C., Jones K., Jensen S., Roman B., Alvarado N., Feldman J. and Scholin C.A. (2008) Field applications of the second generation environmental sample processor (ESP) for remote detection of harmful algae: 2006-2007. Limnology and Oceanography: Methods 6, 667-679.

Haamer J., Andersson P.-O., Lindahl O., Lange S., Li X.P. and Edebo L. (1990) Geographic and seasonal variation of okadic acid content in farmed mussels, Mytilus edulis Linnaeus, 1758, along the Swedish west coast. Journal of Shellfish Research 9, 103-108.

Hai D.-N., Lam N.-N. and Dippner J. (2010) Development of Phaeocystis globosa blooms in the upwelling waters of the South Central coast of Viet Nam. Journal of Marine Systems 83, 253-261.

Hall A. and Frame E.R. (2010) Evidence of domoic acid exposure in harbour seals from Scotland: a potential factor in the decline in abundance? Harmful Algae 9, 489-493.

Hallegraeff G.M. (1993) A review of harmful algal blooms and their apparent global increase. Phycologia 32, 79-99. 
Hallegraeff G.M. (2010) Ocean climate change, phytoplankton community responses, and harmful algal blooms: a formidable predictive challenge. Journal of Phycology 46, 220-253.

Hallegraeff G.M. and Bolch C.J. (1992) Transport of diatom and dinoflagellate resting spores in ships' ballast water: implications for plankton biogeography and aquaculture. Journal of Plankton Research 14, 1067-1084

Hays G.C., Richardson A.J. and Robinson C. (2005) Climate change and marine plankton. Trends in Ecology and Evolution 20, 337-344.

He R., McGillicuddy D.J., Keafer B.A. and Anderson D.M. (2008) Historic 2005 toxic bloom of Alexandrium fundyense in the western Gulf of Maine: 2. Coupled Biophysical Numerical Modeling. Journal of Geophysical Research-Oceans 113, Co7040.

Hess P. (2002) Use of LC-MS testing to identify lipophilic toxins, to establish local trends and interspecies differences and to test the comparability of LC-MS testing with the mouse bioassay: an example from the Irish biotoxin monitoring programme 2001. In Villalba A., Reguera B., Romalde J.L. and Beiras R. (eds) Fourth International Conference on Molluscan Shellfish Safety, 4-8 June, 2002. Santiago de Compostela: IOC of UNESCO, pp. 57-66.

Hess P. (2010) Requirements for screening and confirmatory methods for the detection and quantification of marine biotoxins in end-product and official control. Analytical and Bioanalytical Chemistry 397, $1683-1694$

Hess P. (2012) Phytoplankton and biotoxin monitoring programmes for the safe exploitation of shellfish in Europe. In Cabado A.G. and Vieites J.M. (eds) New trends in marine and freshwater toxins: food safety concerns. New York, NY: Nova Science Publishers, pp. 305-314.

Hess P., Abadie E., Herve F., Berteaux T., Sechet V., Araoz R., Molgo J., Zakarian A., Sibat M., Rundberget T., Miles C.O. and Amzil Z. (2013) Pinnatoxin G is responsible for atypical toxicity in mussels (Mytilus galloprovincialis) and clams (Venerupis decussata) from Ingril, a French Mediterranean lagoon. Toxicon 75, 16-26.

Hess P., Amzil Z., Belin C., Compere C., Lassus P. and Menesguen A. (2012) Evolution of European monitoring systems for shellfish toxins - an increased need for the surveillance of phytoplankton. In Pagou K.A. and Hallegraeff G.M. (eds) Proceedings of the 14th International Conference on Harmful Algae, 1-5 November 2010, Hersonissos, Crete. Copenhagen: International Society for the Study of Harmful Algae and IOC of UNESCO, pp. 288-291.

Hess P., Grune B., Anderson D.B., Aune T., Botana L.M., Caricato P. van Egmond H.P., Halder M., Hall S., Lawrence J.F., Moffat C., Poletti R., Richmond J., Rossini G.P., Seamer C. and Serratosa Vilageliu J. (2006) Three Rs approaches in marine biotoxin testing - the report and recommendations of a joint ECVAM/DG SANCO workshop (ECVAM Workshop 55). Alternatives to Laboratory Animals (ATLA) 34, 193-224.

Hess P., McCarron P., Krock B., Kilcoyne J. and Miles C.O. (2014) Azaspiracids: chemistry, biosynthesis, metabolism and detection. In Botana L. (ed.) Seafood and freshwater toxins. pharmacology, physiology and detection, 3 rd edn. Boca Raton, FL: CRC Press, pp. 799-821.

Heymann D.L. (2004) Control of communicable diseases manual, 18th edn. Washington, DC: American Public Health Association.

Higman W.A., Stone D.M. and Lewis J.M. (2001) Sequence comparisons of toxic and non-toxic Alexandrium tamarense (Dinophyceae) isolates from UK waters. Phycologia 40, 256-262.

Hinder S.L., Hays G.C., Edwards M., Roberts E.C., Walne A.W. and Gravenor M.B. (2012) Changes in marine dinoflagellate and diatom abundance under climate change. Nature Climate Change 2, 271-275.

Hiolski E.M., Preston S.K., Frame E.R., Myers M.S., Bammler T.K., Beyer R.P., Farin F.M., Wilkerson H.-W., Smith D.R., Marcinek D.J. and Lefebvre K.A. (2014) Chronic low-level domoic acid exposure alters gene transcription and impairs mitochondrial function in the CNS. Aquatic Toxicology 155, 151-159.

Hoagland P., Anderson D.M., Kaoru Y. and White A.W. (2002) The economic effects of harmful algal blooms in the United States: estimates, assessment issues, and information needs. Estuaries 25, 677-695.

Hoagland P., Jin D., Beet A., Kirkpatrick B., Reich A., Ullman S., Fleming L.E. and Kirkpatrick G. (2014) The human health effects of Florida Red Tide (FRT) blooms: an expanded analysis. Environment International 68, 144-153.

Hoagland P., Jin D., Polansky L.Y., Kirkpatrick B., Kirkpatrick G., Fleming L.E., Reich A., Watkins S.M., Ullmann S.G. and Backer L.C. (2009) The costs of respiratory illnesses arising from Florida Gulf Coast Karenia brevis blooms. Environmental Heath Perspectives $117,1239-1243$.

Hoagland P. and Scatasta S. (2006) The economic effects of harmful algal blooms. In Granéli E. and Turner J.T. (eds) Ecology of harmful algae. New York, NY: Springer-Verlag, pp. 391-402.

Hu C. and He M.-X. (2008) Origin and offshore extent of floating algae in Olympic sailing area. Eos Transactions American Geosciences Union, $302-303$.

ICES (2006) Report of the ICES-IOC Working Group on Harmful Algal Bloom Dynamics (WGHABD), 3-6 April 2006, Gdynia, Poland. ICES CM 2006/OCC:04. 47 pp.

ICES (2015) Report of the International Council for the Exploration of the Sea - IOC Working Group on Harmful Algal Bloom Dynamics (WGHABD), 28 April-2 May 2014, Haarlem, the Netherlands. ICES CM 2014/SSGHIE: 12, 87 pp.

Illoul H., Rodríguez F., Vila M., Adjas N., Aït Younes A., Bournissa M., Koroghli A., Marouf N., Rabia S. and Ameur F.L.K. (2012) The genus Ostreopsis along the Algerian coastal waters (SW Mediterranean Sea) associated with a human respiratory intoxication episode. Cryptogamie, Algologie 33, 209-216.

Imai I., Shimada H., Shinada A., Baba K., Kanamori M., Sato M., Kuwahara Y., Miyoshi K., Tada M., Hirano K., Miyazono A. and Itakura S. (2014) Prediction of toxic algal bloom occurrences and adaptation to toxic blooms to minimize economic loss to the scallop aquaculture industry in Hokkaido, Japan. In Trainer V.L. and Yoshida T. (eds) Proceedings of the workshop on economic impacts of harmful algal blooms on fisheries and aquaculture. PICES Scientific Report No. 47. Sidney, BC: North Pacific Marine Science Organization (PICES), 85 pp.

IPCC (2008) Climate change 2007 - impacts, adaptation and vulnerability. Working Group II contribution to the Fourth Assessment Report of the IPCC Intergovernmental Panel on Climate Change. Available at: http://www.ipcc.ch/ (last accessed 16 January 2010).

Jackson J.J., Stivala C.E., Iorga B.I., Molgo J. and Zakarian A. (2012) Stability of cyclic imine toxins: interconversion of pinnatoxin amino ketone and pinnatoxin A in aqueous media. Journal of Organic Chemistry 77, 10435-10440.

Jauffrais T., Kilcoyne J., Séchet V., Herrenknecht C., Truquet P., Hervé F., Bérard J.B., Nulty C., Taylor S., Tillmann U., Miles C.O. and Hess P. (2012) Production and isolation of azaspiracid-1 and-2 from Azadinium spinosum culture in pilot scale photobioreactors. Marine Drugs 10, $1360-1382$.

Jessup D.A., Miller M.A., Ryan J.P., Nevins H.M., Kerkering H.A., Mekebri A., Crane D.B., Johnson T.A. and Kudela R.M. (2009) Mass stranding of marine birds caused by a surfactant-producing red tide. PLOS ONE 4, e4550.

Jiang L., Eriksson J., Lage S., Jonasson S., Shams S., Mehine M., Ilag L.L. and Rasmussen U. (2014a) Diatoms: a novel source for the neurotoxin BMAA in aquatic environments. PLoS ONE 9, e84578. 
Jiang S.S., Kuwano K., Ishikawa N., Yano M., Takatani T. and Arakawa $\mathrm{O}$. (2014b) Production of domoic acid by laboratory culture of the red alga Chondria armata. Toxicon 92, 1-5.

Jin D., Thunberg E. and Hoagland P. (2008) Economic impact of the 2005 red tide event on commercial shellfish fisheries in New England. Ocean and Coastal Management 51, 420-429.

Johnson R.C., Zhou Y., Statler K., Thomas J., Cox F., Hall S. and Barr J.R. (2009) Quantification of saxitoxin and neosaxitoxin in human urine utilizing isotope dilution tandem mass spectrometry. Journal of Analytical Toxicology 33, 8-14.

Kaartvedt S., Johnsen T.M., Aksens D.L., Lie U. and Svendsen H. (1991) Occurrence of the toxic phytoflagellate Prymnesium parvum and associated fish mortality in a Norwegian fjord system. Canadian Journal of Fisheries and Aquatic Science 48, 2316-2323.

Kat M. (1983) Diarrhetic mussel poisoning in the Netherlands related to the dinoflagellate Dinophysis acuminata. Antonie van Leeuwenhoek 49, 417-427.

Kibler S.R., Tester P.A., Kunkel K., Moore S.K. and Litaker R.W. (2015) Effects of ocean warming on growth and distribution of dinoflagellates associated with ciguatera fish poisoning in the Caribbean. Ecological Modelling 316, 194-210.

Kilcoyne J., Jauffrais T., Twiner M.J., Doucette G.J., Aasen J.A.B., Sosa S., Krock B., Séchet V., Nulty C., Salas R., Clarke D., Geraghty J., Duffy C., Foley B., John U., Quilliam M.A., McCarron P., Miles C.O., Silke J., Cembella A., Tillmann U. and Hess P. (2014) Azaspiracids - toxicological evaluation, test methods and the source organisms (ASTOX II). Final Project Report. Galway: Marine Institute.

Kilcoyne J., Keogh A., Clancy G., LeBlanc P., Burton I.W., Quilliam M.A., Hess P. and Miles C.O. (2012) Improved isolation procedure for Azaspiracids from shellfish, structural elucidation of azaspiracid-6, and stability studies. Journal of Agricultural and Food Chemistry 60, 2447-2455

Kim C.S., Lee S.G., Lee C.K., Kim H.G. and Jung J. (1999) Reactive oxygen species as causative agents in the ichthyotoxicity of the red tide dinoflagellate Cochlodinium polykrikoides. Journal of Plankton Research 21, 2105-2115.

Kim H.G. (2006) Mitigation and controls of HABs. In Granéli E. and Turner J.T. (eds) Ecology of harmful algae. Ecological Studies, Vol. 189. Berlin: Springer-Verlag, pp. 327-338.

Kim H.-J., Miller A.J., McGowan J. and Carter M.L. (2009) Coastal phytoplankton blooms in the Southern California Bight. Progress in Oceanography 82, 137-147.

Kirkpatrick B., Bean J.A., Fleming L.E., Kirkpatrick G., Grief L., Nierenberg K., Reich A., Watkins S. and Naar J. (2010) Gastrointestinal emergency room admissions and Florida red tide blooms. Harmful Algae 9, 82-86.

Kirkpatrick B., Fleming L.E., Squicciarini D., Backer L.C., Clark R.C. Abraham W., Benson J., Cheng Y.S., Johnson D., Pierce R., Zaias J., Bossart G.D. and Baden D.G. (2004) Literature review of Florida red tide: implications for human health effects. Harmful Algae 3, 99-115.

Klontz K.C., Abraham A., Plakas S.M. and Dickey R.W. (2009) Mussel-associated azaspiracid intoxication in the United States. Annals of Internal Medicine 150, 361-361.

Koike K., Sato S., Yamaji M., Nagahama Y., Kotaki Y., Ogata T. and Kodama M. (1998) Occurrence of okadaic acid-producing Prorocentrum lima on the Sanriku coast, northern Japan. Toxicon 36, 2039-2042.

Kremp A., Godhe A., Egardt J., Dupond S., Suikkanen S., Casabianca S. and Penna A. (2012) Intraspecific variability in the response of bloomforming marine microalgae to changed climate conditions. Ecology and Evolution 2, 2195-2207.
Kudela R.M. and Gobler C.J. (2012) Harmful dinoflagellate blooms caused by Cochodinium sp. Global expansion and ecological strategies facilitating bloom formation. Harmful Algae 14, 71-86.

Lancelot C., Billen G., Sournia A., Weisse T., Colijn F., Veldhuis M.J.W., Davies A. and Wassman P. (1987) Phaeocystis blooms and nutrient enrichment in the continental coastal zones of the North Sea. Ambio 16, 38-46.

Lancelot C. and Mathot S. (1987) Dynamics of a Phaeocystis-dominated spring bloom in Belgian coastal waters. I. Phytoplanktonic activities and related parameters. Marine Ecology Progress Series 37, 239-249.

Landsberg J. (2002) The effects of harmful algal blooms on aquatic organisms. Reviews in Fisheries Science 10, 113-390.

Landsberg J.H., Hall S., Johannessen J.N., White K.D., Conrad S.M., Abbott J.P., Felwelling L.J., Richardson R.W., Dickey R.W., Jester E.L.E., Etheridge S.M., Deeds J.R., Van Dolah F.M., Leighfield T.A., Zou Y., Beaudry C.G., Benner R.A., Rogers P.L., Scott P.S., Kawabata K., Wolny J.L. and Steidinger K.A. (2006) Saxitoxin puffer fish poisoning in the United States, with the First Report of Pyrodinium bahamense as the putative toxin source. Environmental Health Perspective 114, 1502-1507.

Lane J.Q., Raimondi P.T. and Kudela R.M. (2009) Development of a logistic regression model for the prediction of toxigenic Pseudo-nitzschia blooms in Monterey Bay, California. Marine Ecology Progress Series 383, 37-51.

Lange W.R., Snyder F.R. and Fudala P.J. (1992) Travel and ciguatera fish poisoning. Archives of Internal Medicine 152, 2049-2053.

Larkin S. and Adams C. (2007) Harmful algal blooms and coastal business: economic consequences in Florida. Society and Natural Resources 20, 849-859.

Lassus P., Bardouil M., Truquet I., Le Baut C. and Pierre M.J. (1985) Dinophysis acuminata distribution and toxicity along the Southern Brittany coast (France): correlation with hydrological parameters. In Anderson D.M., White A.W. and Baden D.G. (eds) Toxic dinoflagellates. Proceedings of the Third International Conference on Toxic Dinoflagellates, New Brunswick, Canada 8-12 June 1985. New York, NY: Elsevier, pp. 159-164.

Lawrence J., Loreal H., Toyufuku H., Hess P., Karunasagar I. and Ababouch L. (2011) Assessment and management of biotoxin risks in bivalve molluscs. FAO Fisheries Technical Paper 551. Rome: FAO Fisheries Department.

Laycock M.V., Anderson D.M., Naar J., Goodman A., Easy D.J., Donovan M.A., Li A., Quilliam M.A., Al Jamali E. and Alshihi R. (2012) Removal of four algal toxins from seawater during desalination using reverse osmosis and distillation. Desalination 293, 1.

Lefebvre K.A., Frame E.R., Gulland F., Hansen J.D., Kendrick P.S., Beyer R.P., Bammler T.K., Farin F.M., Hiolski E.M., Smith D.R. and Marcinek D.J. (2012) A novel antibody-based biomarker for chronic algal toxin exposure and sub-acute neurotoxicity. PloS ONE 7, e36213. doi: 10.1371/journal.pone.0036213.

Lehane L. and Lewis R.J. (2000) Ciguatera: recent advances but the risk remains. International Journal of Food Microbiology 61, 91-125.

Lemée R., Mangiajo L., Cohu S., Amzil Z., Blanfune A., Chomerat N., Ganzin N., Gasparin S., Grossel H., Guidi-Guivar L., Hoareau L., Le Duf F., Marr S., Simo N., Néza E., Pedrott M.L., Séche V., Soliveres O. and Thibaut T. (2012) Interactions between scientists, managers and policy makers in the framework of the French MediOs project on Ostreopsis (2008-2010). Cryptogamie, Algologie 33, 137-142.

Levin E.D., Pizarro P., Pang W.G., Harrison J. and Ramsdell J.S. (2005) Persisting behavioral consequences of prenatal domoic acid exposure in rats. Neurotoxicology and Teratology 27, 719-725. 
Lewis R. and Ruff T.A. (1993) Ciguatera: ecological, clinical and socioeconomic perspectives. Critical Reviews in Environmental Science and Technology 23, 137-156.

Lewitus A.J., Horner R.A., Caron D.A., Garcia-Mendoza E., Hickey B.M., Hunte M., Huppert D.D., Kudela R.M., Langlois G.W., Largier J.L., Lessard E.J., RaLonde R., Rensel J.E.J., Strutton P.G., Trainer V.L. and Tweddle J.F. (2012) Harmful algal blooms along the North American west coast region: history, trends, causes, and impacts. Harmful Algae 19, 133-159.

Lilly E.L., Halanych K.M. and Anderson D.M. (2007) Species boundaries and global biogeography of the Alexandrium tamarense complex (Dinophyceae). Journal of Phycology 43, 1329-1338.

Liss P.S., Malin G., Turner S.M. and Holligan P.M. (1994) Dimethyl sulphide and Phaeocystis: a review. Journal of Marine Systems 5, 41-53.

Litaker R.W., Vandersea M.W., Faust M.A., Kibler S.R., Nau A.W., Holland W.C., Chinain M., Holmes M.J. and Tester P.A. (2010) Global distribution of ciguatera causing dinoflagellates in the genus Gambierdiscus. Toxicon 56, 711-730.

Longhurst A. (2007) Ecological geography of the sea. London: Academic Press.

Louzao M.C., Vilariño N. and Yotsu-Yamashita M. (2014) Polycavernosides and other scarce new toxins. In Botana L.M. (ed.) Seafood and freshwater toxins. Boca Raton, FL: CRC Press, pp. $857-872$.

MacKenzie L. (1991) Toxic and noxious phytoplankton in Big Glory Bay, Stewart Island, New Zealand. Journal of Applied Phycology 3, 19-34.

MacKenzie L., Beuzenberg V., Holland P., McNabb P. and Selwood A. (2004) Solid phase adsorption toxin tracking (SPATT): a new monitoring tool that simulates the biotoxin contamination of filter feeding bivalves. Toxicon $44,901-918$.

MacKenzie L., Smith K., Rhodes L., Brown A., Langi V., Edgar M., Lovell G. and Preece M. (2011) Mortalities of sea-cage salmon (Oncorhynchus tshawytscha) due to a bloom of Pseudochattonella verruculosa (Dictyochophyceae) in Queen Charlotte Sound, New Zealand. Harmful Algae 11, 45-53.

Magaña H.A., Contreras C. and Villareal T.A. (2003) A historical assessment of Karenia brevis in the western Gulf of Mexico. Harmful Algae $2,163-171$

Mangialajo L., Ganzin N., Accoroni S., Asnaghi V., Blanfune A., Cabrini M., Cattaneo-Vietti R., Chavanon F., Chiantore M., Cohu S., Costa E., Fornasaro D., Grossel H., Marco-Miralles F., Masó M., Reñé A., Rossi A.M., Sala M.M., Thibaut T., Totti C., Vila M. and Lemée R. (2011) Trends in Ostreopsis proliferation along the Northern Mediterranean coasts. Toxicon 57, 408-420.

Magnien R.E. (2001) The dynamics of science, perception, and policy during the outbreak of Pfiesteria in the Chesapeake Bay. BioScience $51,843-852$.

Margalef R. (1998) Red tides and ciguatera as successful ways in the evolution and survival of an admirable old phylum. In Reguera B., Blanco J., Fernández M.L. and Wyatt T. (eds) Harmful algae. Proceedings of the VIII International Conference on Harmful Algae, Vigo, Spain, 25-27 June 1997. Santiago de Compostela, Spain Xunta de Galicia and Intergovernmental Oceanographic Commission of UNESCO, pp. 3-7.

Marshall J.A. and Hallegraeff G.M. (1999) Comparative ecophysiology of the harmful alga Chattonella marina (Raphidophyceae) from South Australian and Japanese waters. Journal of Plankton Research 21, $1809-1822$.

Martin J.L., Haya K. and Wildish D.J. (1993) Distribution and domoic acid content of Nitzschia pseudodelicatissima in the Bay of Fundy. In
Smayda T.J. and Shimizu Y. (eds) Toxic phytoplankton blooms in the sea. Amsterdam: Elsevier, pp. 613-618.

Mattei C., Vetter I., Eisenblätter A., Krock B., Ebbecke M., Desel H. and Zimmermann K. (2014) Ciguatera fish poisoning: a first epidemic in Germany highlights an increasing risk for European countries. Toxicon 91, 76-83.

McCall J.R., Jacocks H.M., Baden D.G. and Bourdelais A.J. (2012) Development of a competitive fluorescence-based synaptosome binding assay for brevetoxins. Harmful Algae 19, 85-91.

McCarron P., Rourke W.A., Hardstaff W., Pooley B. and Quilliam M.A. (2012) Identification of pinnatoxins and discovery of their fatty acid ester metabolites in mussels (Mytilus edulis) from Eastern Canada. Journal of Agricultural and Food Chemistry 60, 1437-1446.

McGillicuddy D.J. Jr, Anderson D.M., Lynch D.R. and Townsend D.W. (2005) Mechanisms regulating large-scale seasonal fluctuations in Alexandrium fundyense populations in the Gulf of Maine: results from a physical-biological model. Deep-Sea Research Part II 52, $2698-2714$.

McKee D., Fleming L.E., Tamer R. and Weisman R. (2001) Ciguatera fish poisoning reporting by physicians in an endemic area. In Hallegraeff G.M., Blackburn S.I., Bolch C.J. and Lewis R.J. (eds) Harmful algal blooms 20oo. Paris: IOC of UNESCO, pp. 451-453.

Medcof J.F.R. (1985) Life and death with Gonyaulax: an historical perspective. In Anderson D.M., White A.W. and Baden D.G. (eds) Toxic dinoflagellates. Proceedings of the Third International Conference on Toxic Dinoflagellates, New Brunswick, Canada, 8-12 June 1985. New York, NY: Elsevier Science, pp. 1-10.

Medlin L.K., Lange M., Wellbrock U., Donner G., Elbrachter M., Hummert C. and Luckas B. (1998) Sequence comparisons link toxic European isolates of Alexandrium tamarense from the Orkney Islands to toxic North American stocks. European Journal of Protistology 34, 329-335.

Milian A., Nierenberg K., Fleming L., Bean J.A., Wanner A., Reich A., Backer L.C., Jayroe D. and Kirkpatrick B. (2007) Reported asthma symptom intensity during exposure to aerosolized Florida red tide toxins. Journal of Asthma 44, 583-587.

Moestrup Ø., Akselman R., Cronberg G., Elbraechter M., Fraga S., Halim Y., Hansen G., Hoppenrath M., Larsen J., Lundholm N., Nguyen L.N. and Zingone A. (2009) IOC-UNESCO taxonomic reference list of harmful micro algae. Accessed at http://www.marinespecies. org/hab (last accessed 20 April 2015).

Molgó J., Aráoz R., Benoit E. and Iorga B.I. (2014) Cyclic imine toxins. In Botana L.M. (ed.) Seafood and freshwater toxins, 3 rd edn. Boca Raton, FL: CRC Press, pp. 951-99o.

Moore S.K., Johnstone J.A., Banas N.S. and Salathé E.P. Jr (2015) Present-day and future climate pathways affecting Alexandrium blooms in Puget Sound, WA, USA. Harmful Algae 48, 1-11.

Moore S.K., Trainer V.L., Mantua N.J., Parker M.S., Laws E.A., Backer L.C. and Fleming L.E. (2008) Impacts of climate variability and future climate change on harmful algal blooms and human health. Environmental Health 7, Supplement 2, 1-12.

Morgan K., Larkin S.L. and Adams C.M. (2010) Red tides and participation in marine-based activities: estimating the response of Southwest Florida residents. Harmful Algae 9, 333-341.

Morris P., Campbell D.S., Taylor T.J. and Freeman J.I. (1991) Clinical and epidemiological features of neurotoxic shellfish poisoning in North Carolina. American Journal of Public Health 81, 471-473.

Mudie P.J., Rochon A. and Levac E. (2002) Palynological records of red tide-producing species in Canada: past trends and implications for the future. Palaeogeography, Palaeoclimatology, Palaeoecology $180,159-186$ 
Murray S. and Suthers I. (1999) Population ecology of Noctiluca scintillans Macartney, a red-tide forming dinoflagellate. Marine and Freshwater Research 50, 243-252.

Naar J.P., Flewelling L.J., Lenzi A., Abbott J.P., Granholm A., Jacocks H.M., Gannon D., Henry M., Pierce R., Baden D.G., Wolny J. and Landsberg J.H. (2007) Brevetoxins, like ciguatoxins, are potent ichthyotoxins that accumulate in fish. Toxicon 50, 707-723.

Nakamura Y., Suzuki S.Y. and Hiromi J. (1995) Population dynamics of heterotrophic dinoflagellates during a Gymnodinium mikimotoi red tide in the Seto Inland Sea. Marine Ecology Progress Series 125, 269-277.

Nishiwaki-Matsushima R., Ohta T., Nishiwaki S., Suganuma M., Kohyama K., Ishikawa T., Carmichael W.W. and Fujiki H. (1992) Liver cancer promotion by the cyanobacterial cyclic peptide toxin microcystin-LR. Journal of Cancer Research and Clinical Oncology $118,420-424$.

Noguchi T., Hwang D.F., Arakawa O., Daigo K., Sato S., Ozaki H. and Kawai N. (1987) Palytoxin as the causative agent in parrotfish poisoning. In Gopalakrishnakone P. and Tan C.K. (eds) Progress in venom and toxin research. Singapore: National University of Singapore, pp. 325-335.

O'Connor A. (2008) The claim: never eat shellfish in a month without an r. The New York Times. Available online: http://www.nytimes.com/ 2008/07/22/health/nutrition/22real.html?_r=o (accessed 4 November 2015).

Olson R.J. and Sosik H.M. (2007) A submersible imaging-in-flow instrument to analyze nano- and microplankton: imaging FlowCytobot. Limnology and Oceanography: Methods 5, 195-203.

Parsons G., Morgan A., Whitehead J.C. and Haab T.C. (2006) The welfare effects of Pfiesteria-related fish kills in seafood markets: a contingent behavior analysis. Agricultural and Resource Economic Review $35,348-356$.

Paz B., Riobó P., Fernández M.L., Fraga S. and Franco J.M. (2004) Production and release of yessotoxins by the dinoflagellates Protoceratium reticulatum and Lingulodinium polyedrum in culture. Toxicon 44, 251-258.

Pennotti R., Scallan E., Backer L., Thomas J. and Angulo F.J. (2013) Ciguatera and scombroid fish poisoning in the United States. Foodborne Pathogens and Disease 10, 1059-1066.

Place A.R., Munday R. and Munday J.S. (2014) Acute toxicity of karlotoxins to mice. Toxicon 90, 184-190.

Pottier I., Vernoux J.P. and Lewis R.J. (2001) Ciguatera fish poisoning in the Caribbean Islands and Western Atlantic. Reviews of Environmental Contamination and Toxicology 168, 99-141.

Powers L., Creed I.F. and Trick C.G. (2015) Sinking of Heterosigma akashiwo results in increased toxicity of this harmful algal bloom species. Harmful Algae 13, 95-104.

Proença L.A.O., Boemer G.L., Dias J.P., Hatherly M.M., Mendes I.L., Mendes L.A.M., Mendes M.C.Q., Rossi W.C., Tamanaha M.S., Tenenbaum D.R. and Schramm M.A. (2010) Can the cases of airborne intoxication of beach users in south coast of Bahia $\left(16^{\circ} 24^{\prime} \mathrm{S}\right.$ $39^{\circ} \mathrm{oz}^{\prime} \mathrm{W}$ ) be related to microalgae? GEOHAB Open Science Meeting: HABs in Benthic Systems, Honolulu, Hawai'i, 21-23 June.

Radke E.G., Reich A. and Morris J.G. Jr (2015) Epidemiology of ciguatera in Florida. American Journal of Tropical Medicine and Hygiene $93,425-432$.

Raine R., McDermott G., Silke J., Lyons K., Nolan G. and Cusack C. (2010) A simple model for the prediction of harmful algal events in the bays of southwestern Ireland. Journal of Marine Systems 83, $150-157$.
Raine R., O'Boyle S., O'Higgins T., White M., Patching J., Cahill B. and McMahon T. (2001) A satellite and field portrait of a Karenia mikimotoi bloom off the south coast of Ireland, August 1998. Hydrobiologia $465,187-193$.

Ramos P.B., Dieh F., dos Santos J.M., Monserrat J.M. and Yunes J.S. (2014) Oxidative stress in rats induced by consumption of saxitoxin contaminated drink water. Harmful Algae 37, 68-74.

Ramstad H., Hovgaard P., Yasumoto T., Larsen S. and Aune T. (2001) Monthly variations in diarrhetic toxins and yessotoxin in shellfish from coast to the inner part of the Sognefjord, Norway. Toxicon 39, $1035-1043$.

Reguera B. and Pizarro G. (2008) Planktonic dinoflagellates which contain polyether toxins of the old "DSP Complex". In Botana L.M. (ed.) Seafood and freshwater toxins: pharmacology, physiology and detection, 2nd edn. London: Taylor and Francis, pp. 257-284.

Reguera B., Riobó P., Rodríguez F., Díaz P.A., Pizarro G., Paz B., Franco J.M. and Blanco J. (2014) Causative organisms, distributions and fate in shellfish. Marine Drugs 12, 394-461.

Reguera B., Velo-Suárez L., Raine R. and Park M.G. (2012) Harmful Dinophysis species: a review. Harmful Algae 14, 87-106.

Reich A., Lazensky R., Faris J., Fleming L.E., Kirkpatrick B., Watkins S., Ullman S., Kohler K. and Hoagland P. (2015) Assessing the impact of shellfish harvesting area closures on neurotoxic shellfish poisoning (NSP) incidence during red tide (Karenia brevis) blooms. Harmful Algae 43, 13-19.

Reiss C.R., Robert C., Owen C. and Taylor J.S. (2006) Control of MIB, geosmin and TON by membrane systems. Journal of Water Supply: Research and Technology - AQUA 55, 95-108.

Réveillon D., Abadie E., Sechet V., Brien L., Savar V., Bardouil M., Hess P. and Amzil Z. (2014) Beta-N-methylamino-L-alanine: LC-MS/MS optimization, screening of cyanobacterial strains and occurrence in shellfish from Thau, a French Mediterranean Lagoon. Marine Drugs $12,5441-5467$.

Réveillon D., Abadie E., Séchet V., Masseret E., Hess P. and Amzil Z. (2015) $\beta$-methylamino-L-alanine (BMAA) and isomers: distribution in different food web compartments of Thau Lagoon, French Mediterranean Sea. Marine Environmental Research 110, 8-18.

Rhodes L. (2011) World-wide occurrence of the toxic dinoflagellate genus Ostreopsis Schmidt. Toxicon 57, 400-407.

Rhodes L., Smith K., Selwood A., McNabb P., Munday R., Suda S., Molenaar S. and Hallegraeff G. (2011) Dinoflagellate Vulcanodinium rugosum identified as the causative organism of pinnatoxins in Australia, New Zealand and Japan. Phycologia 50, 624-628.

Rhodes L., Smith K., Selwood A.I., McNabb P., van Ginkel R., Holland P.T. and Munday R. (2010) Production of pinnatoxins by a peridinoid dinoflagellate isolated from Northland, New Zealand. Harmful Algae 9, 384-389.

Richlen M.L., Morton S.L., Jamali E.A., Rajan A. and Anderson D.M. (2010) The catastrophic 2008-2009 red tide in the Arabian Gulf region, with observations on the identification and phylogeny of the fish-killing dinoflagellate Cochlodinium polykrikoides. Harmful Algae 9, $163-172$

Rongo T. and van Woesik R. (2012) Socioeconomic consequences of ciguatera poisoning in Rarotonga, southern Cook Islands. Harmful Algae 20, 92-100.

Roué M., Cruchet P., Ung A., Darius T., Chinain M. and Laurent D. (2013) Giant clams: new vectors of ciguatera? Toxicon 75, 206.

Roué M., Gugger M., Golubic S., Amzil Z., Aráoz R., Turquet J., Chinain M. and Laurent D. (2014) Marine cyanotoxins potentially harmful to human health. In La Barre S. and Kornprobst J.-M. (eds) 
Outstanding marine molecules. Weinheim: Wiley-VCH Verlag GmbH and Co. KGaA, pp. 1-22.

Ruiz N., Petit K., Vansteelandt M., Kerzaon I., Baudet J., Amzil Z., Biard J.F., Grovel O. and Pouchus Y.F. (2010) Enhancement of domoic acid neurotoxicity on Diptera larvae bioassay by marine fungal metabolites. Toxicon 55, 805-810.

Rundberget T., Aasen J.A.B., Selwood A.I. and Miles C.O. (2011) Pinnatoxins and spirolides in Norwegian blue mussels and seawater. Toxicon 58, 700-711.

Ryan J.P., Chavez F.P. and Bellingham J.G. (2005) Coastal ocean physics and red tides. An example from Monterey Bay, California. Oceanography 18, 246-255.

Ryan J.P., Greenfield D., Marin III R., Preston C., Roman B., Jensen S., Pargett D., Birch J., Mikulski C., Doucette G. and Scholin C. (2011) Harmful phytoplankton ecology studies using an autonomous molecular analytical and ocean observing network. Limnology and Oceanography 56, 1255-1272.

Sansoni G., Borghini B., Camici G., Casotti M., Righini P. and Rustighi C. (2003) Fioriture algali di Ostreopsis ovata (Gonyaulacales: Dinophyceae): un problema emergente. Biologia Ambientale 17, 17-23.

Satake M., Ofuji K., Naoki H., James K.J., Furey A., McMahon T., Silke J. and Yasumoto T. (1998) Azaspiracid, a new marine toxin having unique spiro ring assemblies, isolated from Irish mussels, Mytilus edulis. Journal of the American Chemical Society 120, 9967-9968.

Satake M., Shoji M., Oshima Y., Naoki H., Fujita T. and Yasumoto T. (2002) Gymnocin-A, a cytotoxic polyether from the notorious red tide dinoflagellate, Gymnodinium mikimotoi. Tetrahedron Letters 43, 5829-5832.

Scatasta S., Stolte W., Granéli E. and van Ierland E. (2003) the socio economic impact of harmful algal blooms in european marine waters and description of future risks. Fifth Deliverable for the EU-funded project ECOHARM.

Schoemann V., Becquevort S., Stefels J., Rousseau V. and Lancelot C. (2005) Phaeocystis blooms in the global ocean and their controlling mechanisms: a review. Journal of Sea Research 53, 43-66.

Scholin C., Doucette G., Jensen S., Roman B., Pargett D., Marin III R., Preston C., Jones W., Feldman J., Everlove C., Harris A., Alvarado N., Massion E., Birch J., Greenfield D., Vrijenhoek R., Mikulski C. and Jones K. (2009) Remote detection of marine microbes, small invertebrates, harmful algae, and biotoxins using the Environmental Sample Processor (ESP). Oceanography 22, 158-167.

Scholin C.A., Gulland F., Doucette G.J., Benson S., Busman M., Chavez F.P., Cordaro J., DeLong R., De Vogelaere A., Harvey J., Haulena M., Lefebvre K., Lipscomb T. and Van Dolah F.M. (2000) Mortality of sea lions along the central California coast linked to a toxic diatom bloom. Nature 403, 80-84.

Seki T., Satake M., MacKenzie A.L., Kaspar H.F. and Yasumoto T. (1995) Gymnodimine, a new marine toxin of unprecedented structure isolated from New Zealand oysters and the dinoflagellate, Gymnodinium sp. Tetrahedron Letters 36, 7093-7096.

Sellner K.G., Doucette G.J. and Kirkpatrick G.J. (2003) Harmful algal blooms: causes, impacts and detection. Journal of Industrial Microbiology and Biotechnology 30, 383-406.

Sengco M.R. and Anderson D.M. (2004) Controlling harmful algal blooms through clay flocculation. Journal of Eukaryotic Microbiology $51,1067-1072$.

Seubert E.L., Trussell S., Eagleton J., Schnetzer A., Cetinic I., Lauri P., Jones B.H. and Caron D.A. (2012) Algal toxins and reverse osmosis desalination operations: laboratory bench testing and field monitoring of domoic acid, saxitoxin, brevetoxin and okadaic acid. Water Research $46,6563-6573$.
Shears N.T. and Ross P.M. (2009) Blooms of benthic dinoflagellates of the genus Ostreopsis; an increasing and ecologically important phenomenon on temperate reefs in New Zealand and worldwide. Harmful Algae 8, 916-925.

Shumway S.E., Allen S.M. and Boersma P.D. (2003) Marine birds and harmful algal blooms: sporadic victims or under-reported events? Harmful Algae 2, 1-17.

Sierra-Beltrán A., Palafox-Uribe M., Grajales-Montiel J., Cruz-Villacorta A. and Ochoa J.L. (1997) Sea bird mortality at Cabo San Lucas, Mexico: evidence that toxic diatom blooms are spreading. Toxicon 35, 447-453.

Silke J., O'Beirn F. and Cronin M. (2005) Karenia: an exceptional dinoflagellate bloom in western Irish waters, summer 2005. Marine Environment and Health Series 21. Galway: Marine Institute.

Silva C.A., Morais E.C.P., Costa M.D.M., Ribas J.L.C., Guiloski I.C., Ramsdorf W.A., Zanata S.M., Cestari M.M., Oliveira Ribeiro C.A., Magalhaes V.F., Trudeau V.L. and Silva de Assis H.C. (2014) Saxitoxins induce cytotoxicity, genotoxicity and oxidative stress in teleost neurons in vitro. Toxicon $86,8-15$.

Simoni F., Gaddi A., Paolo C.D. and Lepri L. (2003) Harmful epiphytic dinoflagellate on Tyrrhenian Sea reefs. Harmful Algae News 24, 13-14.

Skinner M.P., Brewer T.D., Johnstone R., Fleming L.E. and Lewis R.J. (2011) Ciguatera fish poisoning in the Pacific Islands (1998 to 2008). PLoS Neglected Tropical Diseases 5, e1416. doi: 10.1371/ journal.pntd.0oo1416.

Smayda T.J. (1990) Novel and nuisance phytoplankton blooms in the sea: evidence for a global epidemic. In Granéli E., Sundstrøm B., Edler L. and Anderson D.M. (eds) Toxic marine phytoplankton. New York, NY: Elsevier, pp. 29-40.

Smayda T.J. (1997) Harmful algal blooms: their ecophysiology and general relevance to phytoplankton blooms in the sea. Limnology and Oceanography 42, 1137-1153.

Sosa S., Ardizzone M., Beltramo D., Vita F., Dell'Ovo V., Barreras A., Yasumoto T. and Tubaro A. (2013) Repeated oral co-exposure to yessotoxin and okadaic acid: a short term toxicity study in mice. Toxicon 76, 94-102.

Sournia A. (1995) Red tide and toxic marine phytoplankton of the world ocean: an inquiry into biodiversity. In Lassus P., Arzul G., Erard E., Gentien P. and Marcaillou C. (eds) Harmful marine algal blooms. Proceedings of the 6th International Conference on Toxic Marine Phytoplankton October 1993, Nantes, France. Paris: Lavoisier, pp. 103-112.

Steidinger K.A., Vargo G.A., Tester P.A. and Tomas C.R. (1998) Bloom dynamics and physiology of Gymnodinium breve with emphasis on the Gulf of Mexico. In Anderson D.M., Cembella A.D. and Hallegraeff G.M. (eds) Physiological ecology of harmful algal blooms. Heidelberg: Springer-Verlag, pp. 133-153.

Stewart I., Seawright A.A. and Shaw G.R. (2008) Cyanobacterial poisoning in livestock, wild mammals and birds - an overview. Advances in Experimental Medicine and Biology 6, 613-637.

Stumpf R.P., Litaker R.W., Lanerolle L. and Tester P.A. (2008) Hydrodynamic accumulation of Karenia off the west coast of Florida. Continental Shelf Research 28, 189-213.

Suikkanen S., Kremp A., Hautala H. and Krock B. (2013) Paralytic shellfish toxins or spirolides? The role of environmental and genetic factors in toxin production of the Alexandrium ostenfeldii complex. Harmful Algae 26, 52-59.

Sun J., Hutchins D.A., Feng Y., Seubert E.L., Caron D.A. and Fu F.-X. (2011) Effects of changing $p \mathrm{CO}_{2}$ and phosphate availability on domoic acid production and physiology of the marine harmful bloom 
diatom Pseudo-nitzschia multiseries. Limnology and Oceanography 56 829-840.

Suzuki T. and Watanabe R. (2012) Shellfish toxin monitoring system in Japan and some Asian countries. In Cabado A.G. and Vieites J.M. (eds) New trends in marine and freshwater toxins: food safety concerns. New York, NY: Nova Science Publishers, pp. 347-377.

Tang Y.Z. and Gobler C.J. (2008) Characterization of the toxicity of Cochlodinium polykrikoides isolates from Northeast US estuaries to finfish and shellfish. Harmful Algae 8, 454-462.

Tangen K. (1977) Blooms of Gyrodinium aureolum (Dinophyceae) in north European waters, accompanied by mortality in marine organisms. Sarsia $63,123-133$.

Taniyama S., Arakawa O., Terada M., Nishio S., Takatani T., Mahmud Y. and Noguci T. (2003) Ostreopsis sp., a possible origin of palytoxin (PTX) in parrotfish Scaris ovifrons. Toxicon 42, 37-33.

Tatters A.O., Flewelling L.J., Fu F.-X., Granholm A.A. and Hutchin D.A. (2013) $\mathrm{High} \mathrm{CO}_{2}$ promotes the production of paralytic shellfish poisoning toxins by Alexandrium catenella from Southern California waters. Harmful Algae 30, 37-43.

Tatters A.O., Fu F.-X. and Hutchins D.A. (2012a) High $\mathrm{CO}_{2}$ and silicate limitation synergistically increase the toxicity of Pseudo-nitzschia fraudulenta. PLOS ONE 7, e32116.

Tatters A.O., Schnetzer A., Fu F., Lie A.Y.A., Caron D.A. and Hutchins D.A. (2012b) Short- versus long-term responses to changing $\mathrm{CO}_{2}$ in a coastal dinoflagellate bloom: implications for interspecific competitive interactions and community structure. Evolution 67, 1879-1891.

Taylor F.J.R. and Harrison P.J. (2002) Harmful marine algal blooms in western Canada. In Taylor F.J.R. and Trainer V.L. (eds) Harmful algal blooms in the PICES region of the North Pacific, PICES Scientific Report No. 23. Sidney, BC: North Pacific Marine Science Organization (PICES), pp. 77-88.

Taylor M., Mcintyre L., Ritson M., Stone J., Bronson R., Bitzikos O., Rourke W., Galanis E. and Team O. (2013) Outbreak of diarrhetic shellfish poisoning associated with mussels, British Columbia Canada. Marine Drugs 11, 1669-1676.

Tester P.A., Feldman R.L., Nau A.W., Kibler S. and Litaker R.W. (2010) Ciguatera fish poisoning and sea surface temperatures in the Caribbean Sea and the West Indies. Harmful Algae 56, 698-710.

Tester P.A., Kibler S.R., Holland W.C., Usup G., Vandersea M.W., Leaw C.P., Lim P.T., Jacob Larsen J., Mohammad-Noor N., Faust M.A. and Litaker R.W. (2014) Sampling harmful benthic dinoflagellates: comparison of artificial and natural substrate methods. Harmful Algae 39, 8-25.

Tichadou L., Glaizal M., Armengaud A., Grossel H., Lemée R. and Kantin R. (2010) Health impact of unicellular algae of the Ostreopsis genus blooms in the Mediterranean Sea: experience of the French Mediterranean coast surveillance network from 2006 to 2009. Clinical Toxicology 48, 839-844.

Tillmann U. (2003) Kill and eat your predator: a winning strategy of the planktonic flagellate Prymnesium parvum. Aquatic Microbial Ecology $32,73-84$.

Tillmann U., Elbrächter M., Krock B., John U. and Cembella A.D. (2009) Azadinium spinosum gen. et sp. nov. (Dinophyceae) identified as a primary producer of azaspiracid toxins. European Journal of Phycology 44, 63-79.

Tillmann U., Salas R., Jauffrais T., Hess P. and Silke J. (2014) AZA: the producing organisms - biology and trophic transfer. In Botana L.M. (ed.) Seafood and freshwater toxins. Pharmacology, physiology and detection, 3rd edn. Boca Raton, FL: CRC Press, pp. 773-798.

Todd E.C.D. (1993) Domoic acid and amnesic shellfish poisoning - a review. Journal of Food Protection 56, 69-83.
Todd E.C.D. (1995) Estimated costs of paralytic shellfish, diarrhetic shellfish, and ciguatera poisoning in Canada. In Lassus P., Arzul G., Erard E., Gentien P. and Marcaillou-Le Bout C. (eds) Harmful algal blooms. Paris: Lavoisier Science Publishers, pp. 831-834.

Touzet N., Davidson K., Pete R., Flanagan K., McCoy G.R., Amzil Z., Maher M., Chapelle A. and Raine R. (2010) Co-occurrence of the West European (Gr. III) and North American (Gr. I) ribotypes of Alexandrium tamarense (Dinophyceae) in Shetland, Scotland. Protist $161,370-384$

Touzet N., Franco J.M. and Raine R. (2007) Characterization of nontoxic and toxin-producing strains of Alexandrium minutum (Dinophyceae) in Irish coastal waters. Applied Environmental Microbiology 73, 33333342 .

Trainer V.L., Eberhart B.-T.L., Wekell J.C., Adams N.G., Hanson L., Cox F. and Dowell J. (2003) Paralytic shellfish toxins in Puget Sound, Washington State. Journal of Shellfish Research 22, 213-223.

Trainer V.L., Moore L., Bill B.D., Adams N.G., Harrington N., Borchert J., Silva D.A.M. and Eberhart B.-T.L. (2013) Diarrhetic shellfish toxins and other lipophilic toxins of human health concern in Washington State. Marine Drugs 11, 1815-1835.

Trainer V.L. and Suddleson M. (2005) Monitoring approaches for early warning of domoic acid events in Washington state. Oceanography 18 , $228-237$.

Trainer V.L. and Yoshida T. (eds) (2014) Proceedings of the Workshop on Economic Impacts of Harmful Algal Blooms on Fisheries and Aquaculture. PICES Scientific Reports 47, 85 pp

Treasurer J.W., Hannah F. and Cox D. (2003) Impact of a phytoplankton bloom on mortalities and feeding response of farmed Atlantic salmon, Salmo salar, in west Scotland. Aquaculture 218, 103-113.

Tubaro A., Durando P., Del Favero G., Ansaldi F., Icardi G. and Deeds J.R. (2011) Case definitions for human poisonings postulated to palytoxins exposure. Toxicon $57,478-495$.

Turner A., Higgins C., Veszelovski A., Payne D., Davidson K., Hungerford J. and Higman W. (2015) Monitoring of new or emerging marine biotoxins in UK waters: brevetoxins. Marine Drugs 13, $1224-1254$.

Twiner M.J., Doucette G.J., Rasky A., Huang X.-P., Roth B.L. and Sanguinetti M.C. (2012a) The marine algal toxin azaspiracid is an open state blocker of hERG potassium channels. Chemical Research in Toxicology 25, 1975-1984.

Twiner M.J., Hanagriff J.C., Butler S., Madhkoor A.K. and Doucette G.J. (2012b) Induction of apoptosis pathways in several cell lines following exposure to the marine algal toxin azaspiracid. Chemical Research in Toxicology 25, 1493-1501.

Twiner M., Hess P. and Doucette G.J. (2014) Azaspiracids: toxicology, pharmacology, and risk assessment. In Botana L.M. (ed.) Seafood and freshwater toxins. Pharmacology, physiology and detection, $3 \mathrm{rd}$ edn. Boca Raton, FL: CRC Press, pp. 823-855.

Twiner M.J., Rehmann N., Hess P. and Doucette G.J. (2008) Azaspiracid shellfish poisoning: a review on the chemistry, ecology, and toxicology with an emphasis on human health impacts. Marine Drugs 6, 39-72.

Uemura D., Chou T., Haino T., Nagatsu A., Fukuzawa S., Zheng S. and Chen H. (1995) Pinnatoxin A: a toxic amphoteric macrocycle from the Okinawan bivalve Pinna muricata. Journal of the American Chemical Society 117, 1155-1156.

Vale P., Botelho M.J., Rodrigues S.M., Gomes S.S. and Sampayo M. (2008) Two decades of marine biotoxin monitoring in bivalves from Portugal (1986-2006): a review of exposure assessment. Harmful Algae 7, 11-25.

Vanhoutte-Brunier A., Fernand L., Ménesguen A., Lyons S., Gohin F. and Cugier P. (2008) Modelling the Karenia mikimotoi bloom that 
occurred in the western English Channel during summer 2003. Ecological Modelling 210, 351-376.

Van Dolah F.M. (2000) Marine algal toxins: origins, health effects, and their increased occurrence. Environmental Health Perspectives 108, Supplement 1, 133-141.

Van Dolah F.M., Fire S.E., Leighfield T.A., Mikulski T.A. and Doucette G.L. (2012) Determination of paralytic shellfish toxins in shellfish by receptor binding assay: a collaborative study. Journal of AOAC International 95, 795-812.

Van Wagoner R.M., Deeds J.R., Tatters A.O., Place A.R., Tomas C.R. and Wright J.L.C. (2010) Structure and relative potency of several karlotoxins from Karlodinium veneficum. Journal of Natural Products 73, $1360-1365$.

Velo-Suárez L., González-Gil S., Pazos Y. and Reguera B. (2014) The growth season of Dinophysis acuminata in an upwelling system embayment: a conceptual model based on in situ measurements. Deep Sea Research Part II 101, 141-151.

Vila M., Arin L., Battocchi C., Bravo I., Fraga S., Penna A., Reñé A., Riobó P., Rodríguez F., Sala M.M., Camp J., de Torres M. and Franco J.M. (2012) Management of Ostreopsis blooms in recreational waters along the Catalan coast (NW Mediterranean Sea): cooperation between a research project and a monitoring program. Cryptogamie, Algologie 33, 143-152.

Vila M., Masó M., Sampedro N., Illoul H., Arin L., Garcés E., Giacobbe M.G., Àlvarez J. and Camp J. (2008) The genus Ostreopsis in recreational waters of the Catalan Coast and Balearic Islands (NW Mediterranean Sea): is this the origin of human respiratory difficulties? In Moestrup Ø., Doucette G., Enevoldsen H., Godhe A., Hallegraeff G., Luckas, B., Lundholm N., Lewis J., Rengefors K., Selner K., Steidinger K., Tester P. and Zingone A. (eds) Proceedings of the 12th International Conference on Harmful Algae, Copenhagen, Denmark, 4-8 September 20o6. Copenhagen: ISSHA and IOC of UNESCO, pp. 334-336.

Vila M., Riobó P., Bravo I., Masó M., Penna A. and Reñé A. (2014) A Three-year time series of toxic Ostreopsis blooming in a NW Mediterranean coastal site: preliminary results. In Pagou P. and Hallegraeff G. (eds) Proceedings of the 14th International Conference on Harmful Algae. Copenhagen: ISSHA and IOC of UNESCO, pp. 111-113.

Villareal T.A., Hanson S., Qualia S., Jester E.L.E., Granade H.R. and Dickey R.W. (2007) Petroleum production platforms as sites for the expansion of ciguatera in the northwestern Gulf of Mexico. Harmful Algae 6, 253-259.

Watkins S.M., Reich A., Fleming L.E. and Hammond R. (2008) Neurotoxic shellfish poisoning. Marine Drugs 6, 431-455.

Wessells C.R., Miller C.J. and Brooks P.M. (1995) Toxic algae contamination and demand for shellfish: a case study of demand for mussels in Montreal. Marine Resource Economics 10, 143-159.

White A.W. (1984) Paralytic shellfish toxins and finfish. American Chemical Society Symposium Series 262, 171-180.

Whitehead J.C., Haab T.C. and Parsons G.R. (2003) Economic effects of Pfiesteria. Ocean and Coastal Management 46, 845-858.

Whitelegge T. (1891) On the recent discoloration of the waters of Port Jackson. Records of the Australian Museum Sydney 1, 179-192.

Whyte C. (2013) Why its safer to eat shellfish in months with a letter 'R.' Available online: http://theconversation.com/why-its-safer-to-eatshellfish-in-months-with-a-letter-r-20174 (accessed 4 November 2015).
Whyte C., Swan S. and Davidson K. (2014) Changing wind patterns linked to unusually high Dinophysis blooms around the coast of the Shetland Islands, Scotland. Harmful Algae 39, 365-373.

Whyte J.N.C., Haigh N., Ginther N.G. and Keddy L.J. (2001) First record of blooms of Cochlodinium sp (Gymnodiniales, Dinophyceae) causing mortality to aquacultured salmon on the west coast of Canada. Phycologia 40, 298-304

Yamochi S. (1989) Mechanisms for outbreak of Heterosigma akashiwo red tide in Osaka Bay. In Okaichi T., Anderson D.M. and Nemoto T. (eds) Red tides biology, environmental science, and toxicology. Amsterdam: Elsevier, pp. 253-256.

Yasumoto T., Sugawara W., Fukuyo Y., Oguri H., Igarashi T. and Fujita N. (1980) Identification of Dinophysis fortii as the causative organism of diarrhetic shellfish poisoning in the Tohoku district. Bulletin of the Japanese Society of Scientific Fisheries 46, 1405-1411.

Yndestad M. and Underdal B. (1985) Survey of PSP in mussels (Mytilus edulis L.) in Norway. In Anderson D.M., White A.W. and Baden D.G. (eds) Toxic dinoflagellates. Proceedings of the Third International Conference on Toxic Dinoflagellates, New Brunswick, Canada 8-12 June 1985. New York, NY: Elsevier Science, pp. 457-460.

Yuki K. and Yoshimatsu S. (1989) Two fish-killing species of Cochlodinium from Harima-Nada, Seto Inland Sea, Japan. In Okaichi T., Anderson D.M. and Nemoto T. (eds) Red tides: biology, environmental science, and toxicology. New York, NY: Elsevier, pp. 451-454.

Zaias J., Backer L.C. and Fleming L.E. (2010) Harmful algal blooms (HABs). In Rabinowitz P. and Conti L. (eds) Human-animal medicine: a clinical guide to toxins, zoonoses, and other shared health risks. New York, NY: Elsevier Science Publishers, pp. 91-104.

Zendong Z., Herrenknecht C., Abadie E., Brissard C., Tixier C., Mondeguer F., Séchet V., Amzil Z. and Hess P. (2014) Extended evaluation of polymeric and lipophilic sorbents for passive sampling of marine toxins. Toxicon 91, 57-68.

Zhao J., Hu C., Lener J.M., Weisberg R.H., Lembke C., English D., Wolny J., Zheng L., Walsh J.J. and Kirkpatrick G. (2013) Three-dimensional structure of a Karenia brevis bloom: observations from gliders, satellites, and field measurements. Harmful Algae 29, $22-30$.

Zhou M.-Z., Liu D.-Y., Anderson D.M. and Valiela I. (2015) Introduction to the Special Issue on green tides in the Yellow Sea. Estuarine, Coastal and Shelf Science, Part A, 163: 1-7.

and

Zingone A. and Wyatt T. (2005) Harmful algal blooms: keys to the understanding of phytoplankton ecology. In Robinson A.R. and Brinks K.H. (eds) The sea, the global coastal ocean; multiscale interdisciplinary processes, Volume 13. Boston, MA: Harvard University Press, pp. 867-926.

Correspondence should be addressed to: E. Berdalet Institut de Ciències del Mar (CSIC), Passeig Marítim de la Barceloneta, 37-49, 08003 Barcelona, Catalonia, Spain email: berdalet@icm.csic.es 